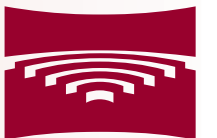

Rīgas STRADINA UNIVERSITĀTE

\title{
Sandra Valeina
}

\section{IEDZIMTAS KATARAKTAS HETEROGENITĀTES IETEKME UZ PSEIDOFAKISKAS ACS REFRAKCIJAS IZMAIN̦ĀM}

Promocijas darbs medicīnas doktora zinātniskā grāda iegūšanai Specialitāte - oftalmoloǵija 
Sandra Valeiņa

\title{
IEDZIMTAS KATARAKTAS HETEROGENITĀTES IETEKME UZ PSEIDOFAKISKAS ACS REFRAKCIJAS IZMAIN̦ĀM
}

\author{
Promocijas darbs \\ medicīnas doktora zinātniskā grāda iegūšanai
}

Specialitāte - oftalmolog̣ija

Darba zinātniskā vadītāja:

Dr. med. profesore Guna Laganovska

Rīga, 2019 


\section{ANOTĀCIJA}

Iedzimta katarakta ir viena no nopietnākajām iespējamu vājredzību izraisošām pediatriskās oftalmoloǵijas slimībām. Tà tiek pieskaitīta retām slimībām, kuras raksturo izplatîba, kas mazāka par pieciem gadījumiem uz 10000 populācijas. Atškirīibā no kataraktas pieaugušam cilvēkam bērna redzes sistēma tikai attīstās, tā ir veidošanās stadijā. Iedzimtas kataraktas jeb bērna acs lēcas apdulļ̧ojuma smaguma pakāpe, tā ārstēšanas iespējas un komplikācijas nopietni ietekmē bērna redzes attīstību. Jo agrīnāks būs kataraktas sākšanās laiks, jo blīvāks, plašāks un centrālāks morfologiski būs acs lēcas apduḷķojums, jo nopietnāks būs apdraudējums bērna redzei. Lai arī Latvija nepieder pie tām pasaules valstīm, kur bērni kḷ̂ust akli neoperētu iedzimtu kataraktu dẹl un kataraktas ķirurǵiskā korekcija pēdējos divdesmit gados ir ļoti strauji attīstījusies gan pasaulē, gan Latvijā, iedzimtas kataraktas ārstēšana joprojām ir izaicinājums gan bērnu oftalmologiem, gan kataraktas ķirurgiem, gan redzes pedagogiem, optometristiem, pediatriem, neonatologiem, medicīnas ǵenētikas speciālistiem, gan bērna vecākiem. Iedzimtas kataraktas izraisītas vājredzības un akluma novēršana ir Pasaules Veselības organizācijas un Starptautiskās akluma novēršanas aǵentūras apvienotā projekta "VISION 2020 - Tiesības redzēt" prioritāte.

Darba mērķis bija pierādīt redzei nozīmīgas iedzimtas kataraktas heterogenitāti, noteikt pseidofakiskas acs refrakcijas izmaiņu lielumu, bērnam augot, kā arī pierādīt refrakcijas izmaiņu ietekmējošos faktorus. Darbā tika analizēti noteiktā laika periodā (01.01.2006.-31.12.2016.) noteiktā reǵionā (Latvijā) visu ķirurǵiski koriǵêto iedzimtas kataraktas pacientu acu dati. Darba izlasē ietilpa 85 iedzimtas kataraktas pacienti vecumā no 0 līdz 18 gadiem ar 138 acīm ar pseidofakiju.

Pētijumā apkopoti, salīdzināti un pētīiti iedzimtas kataraktas raksturojošie lielumi, atrastas statistiski nozīmīgas iedzimtas kataraktas raksturojošo lielumu proporciju atšķirības, kas pierāda iedzimtas kataraktas kā sistēmas unikalitāti un heterogenitāti. Darbā tika pētītas acs refrakcijas izmaiņas acīm ar pseidofakiju, pierādīti un salīdzināti to ietekmējošie faktori. Izprotot acs refrakcijas izmainu ietekmējošos faktorus, iespējams pamatoti izvēlēties optimālo afakijas korekcijas metodi, laikus sekot un koriǵêt atlieku refrakcijas kḹūdas un to izmaiņas. Darbā tika atrasts statistiski ticams acs garuma robežlielums, kuru sasniedzot acs refrakcijas izmaiņas, bērnam augot, pēc kataraktas ekstrakcijas veikšanas ar intraokulārās lēcas implantāciju būs salīdzinoši mazākas un paredzamākas.

Darbā tika izzinātas un salīdzinātas atšḳirīgas intraokulārās lēcas implantācijas taktikas un pierādīta katras acs individuālā intraokulārās lēcas stipruma ietekme uz acs refrakcijas 
izmaiņām. Darbā tika atrastas statistiski ticamas korelācijas un noteiktas procesa atšķirības dažādos bērna vecumos operētām acīm. Pamatojoties uz interdisciplināra darba (neonatologu, medicīnas genētiķu, pediatru, bērnu oftalmologu, kataraktas un priekšējā segmenta acs mikroķirurgu, optometristu, redzes pedagogu) pieredzi, pētījuma rezultātiem un literatūras datiem, izveidotas metodiskas rekomendācijas iedzimtas kataraktas diagnostikai, ārstēšanai un pacientu novērošanai Bērnu klīniskajā universitātes slimnīcā un Latvijā kopumā. 


\section{ANNOTATION}

Congenital cataract is one of the most serious paediatric ophthalmological diseases causing potential weaksightedness. It belongs to rare diseases, characterized by its distribution, lesser than 5 cases per 10000 population. In difference to cataract in adults, the children eyesight system is only developing, consequently, cataract or severity of lens opacity, treatment options and complications interefere or work simultaneously with the eye optic system and children vision development. The earlier is cataract onset time, the denser, wider and more central will be the morphological eye lens opacity, the more serious danger it will be to the eye and children vision development. Although Latvia does not belong to those countries in the world where children become blind due to unoperated congenital cataracts, and the cataract surgical correction in the last twenty years has rapidly developed both in the world, and in Latvia, congenital cataract treatment is still a challange both for paediatric ophthalmologists, catarct surgeons, vision pedagogues, optometricians, paediatricians, neonatologists, medical genetics specialists, and children' parents. Weaksightedness due to congenital cataract and prevention of blindness is the priority of the World Health Organization and the joint project of the International Blindness Prevention Agency "VISION 2020 - Right to See".

The aim of the study was to prove heterogenesity of congenital cataract significant to vision, to determine the size of pseudophakic eye refraction while the child is growing, as well as to define the influential factors of refraction changes. All surgically corrected congenital cataract patients' eye data were analyzed at a certain time period (01.01.2006.-31.12.2016) in a certain region (in Latvia). In the selection were included 87 congenital cataract patients, aged from 0 to 18 years with 137 eyes with pseudophakia. In the study were summarized, compared and investigated the characterizing values of congenital cataracts, statistically significant proportional differences were found of congenital cataracts, which demonstrate the uniqueness and heterogenicity of congenital cataract as a system. In the study the eye refraction changes with paeudophakia were studied, and their influential factors were proved and compared. Understanding the influential factors of the eye refraction changes, one may choose the most optimal aphakia correction method, to follow it up timely and to correct remains of refraction errors and their changes. In the study a statistically significant eye length boundary value was found, and by reaching it the eye refraction changes while the child is growing, which after the surgical correction of cataract extraction by intraocular implantation, will be comparatively smaller and more predictable. Different intraocular lens implantation techniques were found and 
compared and the eye's individual intraocular lens power effect on the eye refraction changes was understood and compared.Statistically significant correlations were found and the process differences at different children ages in the operated eyes were defined. On the basis of the interdisciplinary (neonatologists, medical geneticians, paediatricians, paediatric ophthalmologists, cataract and anterior segment eye microsurgeons, optometricians, vision pedagogues) work experience, the study results and the literature data, there were design methodological recommendations for congenital cataract diagnosis, treatment and patients' observation at Children's Clinical University hospital in Latvia. 


\section{SATURS}

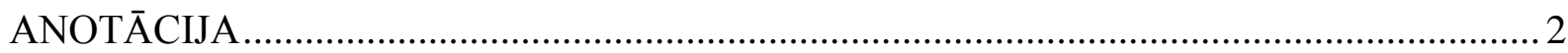

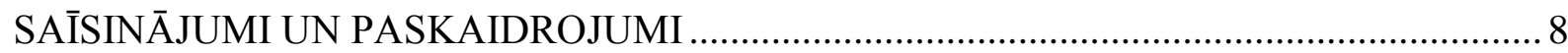

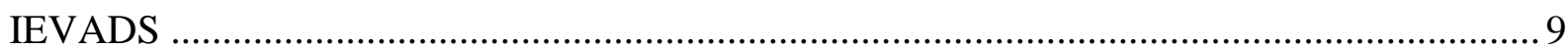

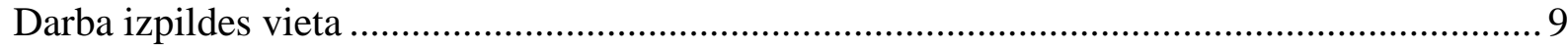

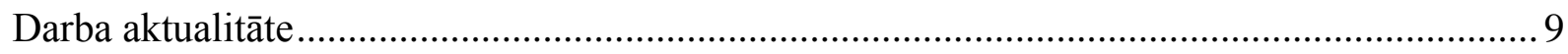

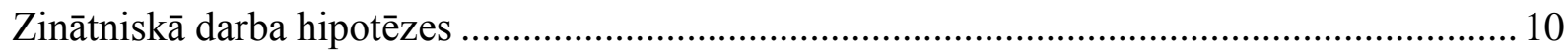

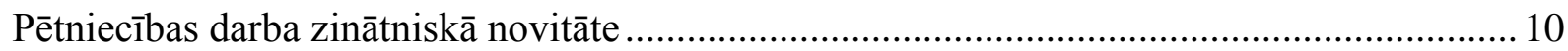

Darba praktiskā vērtība un pētījuma rezultātu ieviešana................................................... 11

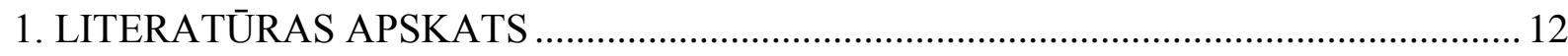

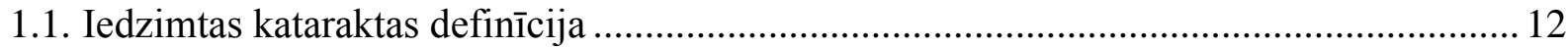

1.2. Iedzimtas kataraktas saistība ar aklumu un vājredzību ............................................. 12

1.3. Iedzimtas kataraktas incidence un prevalence ............................................................ 12

1.4. Acs lēcas un kataraktas veidošanās .................................................................................. 14

1.5. Iedzimtas un bērnu vecuma kataraktas klasifikācijas................................................ 20

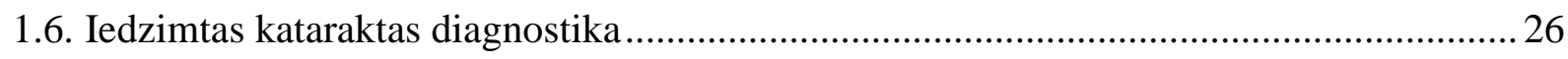

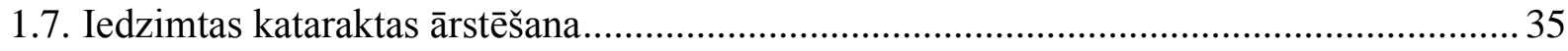

1.8. Pēcoperācijas perioda novērošana (follow up) un iespējamās komplikācijas .................. 40

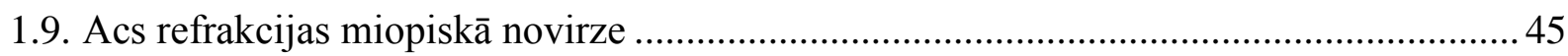

1.10. Redzes prognoze bērniem ar iedzimtu kataraktu.................................................. 48

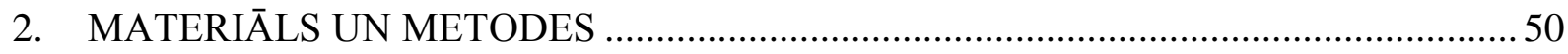

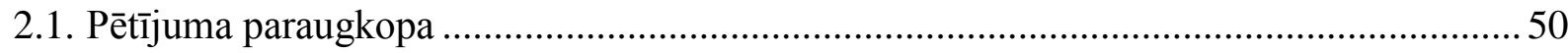

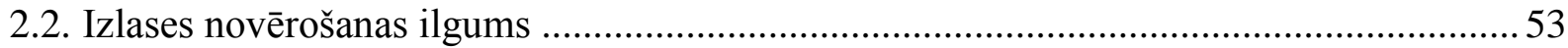

2.3. Acs aksiālā garuma mērījumi un intraokulārās lēcas individuālā stipruma aprēksini,

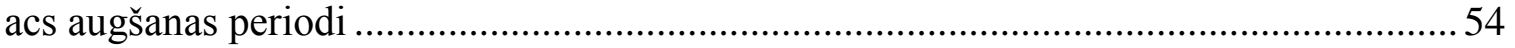

2.4. Intraokulārās lēcas mērķa stiprums un divas intraokulārās lēcas

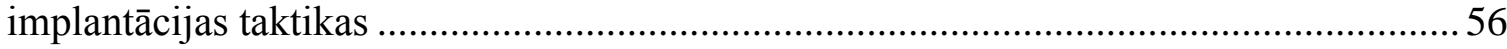

2.5. Refrakcijas izmaiņas jeb miopiskā novirze acīm ar pseidofakiju ................................ 58

2.6. Redzes asuma novērtējums un ambliopijas ārstēšana ............................................... 58

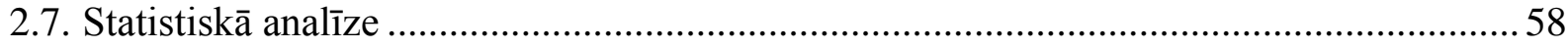




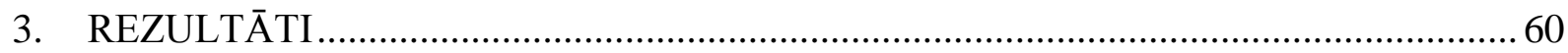

3.1. Iedzimtas kataraktas raksturojošie lielumi - sākšanās laiks, morfoloǵija,

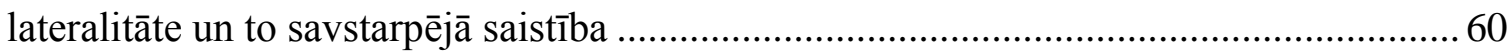

3.2. Iedzimtas kataraktas ārstēšanas laiki, to saistība ar dažādiem ..................................... 63 iedzimtas kataraktas iedalījumiem un ārstēšanas komplikācijām ................................... 63

3.3. Acs refrakcijas izmaiņas - acs miopiskā novirze acīs ar pseidofakiju, to ietekmējošie faktori 66

3.4. Acs ar pseidofakiju refrakcijas izmaiṇu jeb miopiskās novirzes lielumu salīdzinājums, izmantojot dažādas IOL implantācijas mērķa refrakcijas taktikas

3.5. Miopiskās novirzes korelācija ar individuālo intraokulāro lēcu stiprumu acìm ar iedzimtu kataraktu un pseidofakiju.

3.6. Miopiskās novirzes salīdzinājums acīm ar iedzimtu kataraktu un pseidofakiju ar dažādām pēcoperācijas komplikācijām - sekundāru glaukomu un sekundāru kataraktu

3.7. Ķirurğiski ārstētas redzei nozīmīgas iedzimtas kataraktas acs miopiskās novirzes lieluma ietekme uz bērna redzes attīstību .77

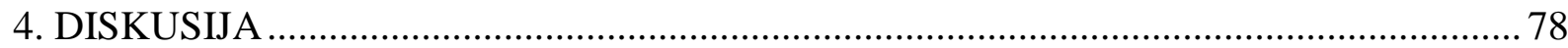

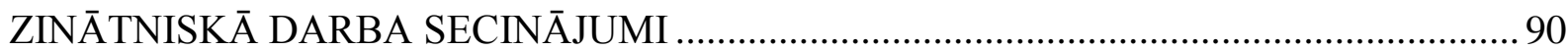

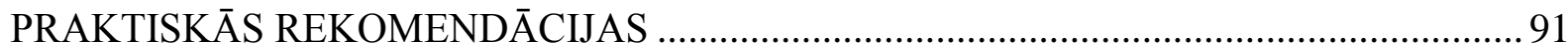

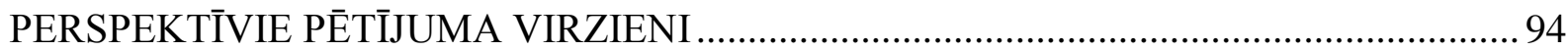

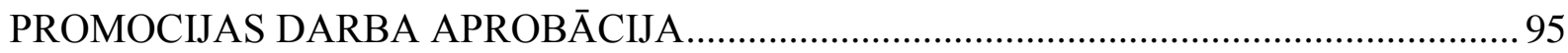

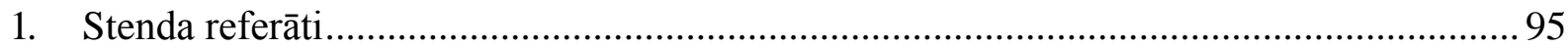

2. Ziṇojumi par promocijas darbu un tā rezultātiem ..................................................... 95

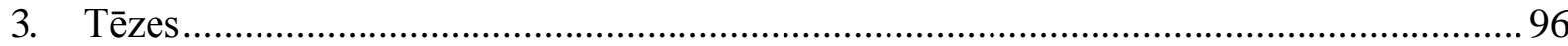

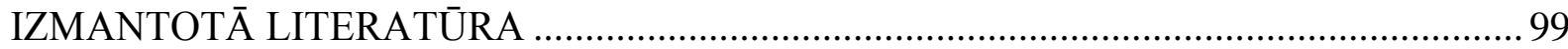

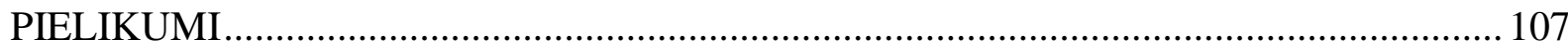




\title{
SAİSINĀJUMI UN PASKAIDROJUMI
}

\author{
AAG \\ acs aksiālais garums \\ ASK \\ Acu slimību klīnika \\ BKUS \\ Bērnu klīniskā universitātes slimnīca \\ BSS \\ balansētais sāls šksīdums (Balanced Salt Solution) \\ ED \\ ekvatoriālais diametrs \\ gauge kanula \\ standartmēroga kanule \\ HPO \\ cilvēka fenotipa ontologija (Human Phenotype Ontology) \\ IATS \\ zīdaiņu afakijas ārstēšanas pētījums (Infant Aphakia Treatment Study) \\ IK \\ iedzimta katarakta \\ IOL \\ intraokulāra mākslīgā lēca \\ IQR \\ starpkvartiḷu izkliedes amplitūda (Interquartile Range) \\ jaundzimušais \\ bērns vecumā no dzimšanas līdz 1 mēnesim \\ $\mathrm{MN}$ \\ miopiskā novirze \\ MR \\ mērķa refrakcija \\ ontologija \\ mācība par esamību, esamības būtību noteicošajām iezīmēm \\ ORPHA \\ Orphanet reto slimību ontologija (Orphanet Rare Disease Ontology) \\ PREDA \\ ar noteiktām slimībām slimojošu pacientu reǵistrs \\ p-vērtība $<0,05$ \\ tika uzskatīta par statistiski nozīmīgu \\ RSU \\ Rīgas Stradiņa universitāte \\ SG \\ sekundāra glaukoma \\ SK \\ sekundāra katarakta \\ SD \\ standartnovirze \\ SPKC \\ Slimību profilakses un kontroles centrs \\ TVL \\ lēcas asinsvadu pārvalks (Tunica Vasculosa Lentis) \\ zīdainis \\ bērns vecumā no viena mēneša līdz vienam gadam
}




\section{IEVADS}

\section{Darba izpildes vieta}

Bērnu klīniskās universitātes slimnīcas Acu slimību klīnika, P. Stradiṇa KUS Acu slimību klīnika, RSU Oftalmoloğijas katedra.

\section{Darba aktualitāte}

Iedzimta katarakta ir nopietna pediatrijas oftalmologijas problēma. Neārstēta redzei nozīmīga katarakta var izraisīt aklumu, samazinātu dz̄̄ves kvalitāti un paaugstinātas sociālekonomiskās izmaksas bērnam, ǵimenei un sabiedrībai [34, 55, 53]. Apmēram 200000 bērnu pasaulē ir akli neoperētas kataraktas dēḷ [34, 30, 80]. Lai iegūtu pēc iespējas labāku redzes prognozi, svarīga loma ir gan iedzimtas kataraktas ārstēšanas laikam un veidam, gan pēcoperācijas acs refrakcijas kḷūdas lielumam, tā korekcijas iespējām un ambliopijas ārstēšanai.

Lai izprastu iedzimtu kataraktu kā unikālu sistēmu, salīdzinātu iedzimtas kataraktas ārstēšanas laika un veida ietekmi uz acs refrakcijas kḷūdas lielumu, tika pētîti iedzimtas redzei nozīmīgas kataraktas veidi, to savstarpējās sakarības, acs refrakcijas kḷūdas lielums un izkliede pēc dažādos laikos un veidos izdarītas kataraktas ekstrakcijas un intraokulārās lēcas implantācijas ķirurǵiskas korekcijas. Tika formulēti un salīdzināti acs refrakcijas kḷūdas ietekmējošie faktori. Darbā tika analizēti noteiktā laika periodā (1.01.2006.-31.12.2016.) noteiktā regionā (Latvijā) iegūtie klīniskie dati.

\section{Pētījuma mērḳis}

Pierādīt pseidofakiskas acs refrakcijas izmaiņu saistību ar iedzimtas kataraktas heterogenitāti, tajā ietverot ķirurğiskas korekcijas laika, veida un acs aksiālā garuma dažādību. 


\section{Darba uzdevumi}

1. Izpētīt redzei nozīmīgas iedzimtas kataraktas raksturojošo lielumu morfologijas, sākšanās laika un lateralitātes savstarpējās sakarības.

2. Noteikt acs refrakcijas izmaiņas pēc iedzimtas redzei nozīmīgas kataraktas ķirurǵiskas korekcijas ar intraokulāras lēcas implantāciju, pierādīt to ietekmējošos faktorus.

3. Salīdzināt acs refrakcijas izmaiņu - miopiskās novirzes - lielumu divām atšksirīgām mērķa refrakcijas IOL implantācijas taktikām - emetropas un hipermetropas mērķa refrakcijas grupai.

4. Salīdzināt miopiskās novirzes lielumu acīm ar dažādu acs aksiālo garumu kataraktas ekstrakcijas un IOL implantācijas ķirurǵiskas korekcijas laikā.

5. Salīdzināt miopiskās novirzes lielumu pseidofakiskām acīm ar dažādu IOL individuālo stiprumu.

6. Izstrādāt metodiskas rekomendācijas redzei nozīmīgas iedzimtas kataraktas izmeklēšanai un ārstēšanai BKUS Acu slimību klīnikā un Latvijā kopumā.

\section{Zinātniskā darba hipotēzes}

1. Iedzimtas kataraktas raksturojošie lielumi - morfoloǵija, sākšanās laiks un lateralitāte savstarpēji nekorelē. Izvēlētais kataraktas korekcijas laiks un veids ir atkarīgs no katras individuālas iedzimtas kataraktas raksturojošiem lielumiem.

2. Acs aksiālais garums operācijas laikā ietekmē pseidofakiskas acs refrakcijas izmaiņas, to lielumu un dispersiju.

3. Dažādas intraokulārās lēcas mērķa refrakcijas taktikas (emetropa un hipermetropa IOL mērķa refrakcija) neietekmē pseidofakiskas acs refrakcijas izmaiņu lielumu, dispersiju, amplitūdu. Katras acs individuālais intraokulārās lēcas stiprums, kas tiek aprēķināts, ņemot vērā acs aksiālo garumu un radzenes izliekumu ķirurǵiskas korekcijas laikā, ietekmē un, iespējams, korelē ar acs refrakcijas izmaiņu lielumu.

\section{Pētniecības darba zinātniskā novitāte}

Darbā atrasti statistiski ticami pierādījumi acs garuma robežlielumam iedzimtas kataraktas ķirurğiskas korekcijas laikā. Acīs, kuru garums ir mazāks par iegūto robežlielumu, pēc ķirurğiskas korekcijas ar intraokulāras lēcas implantāciju veidosies neparedzama un liela acs 
refrakcijas miopiskā novirze. Darbā atrasta statistiski ticama korelācija starp individuālo IOL stiprumu un acs miopiskās novirzes lielumu. Darbā statistiski ticami pierādīts, ka divas atšksirīgas ārstēšanas taktikas, implantējot intraokulāru lēcu, neietekmē acs refrakcijas miopiskās novirzes lielumu.

\section{Darba praktiskā vērtība un pētījuma rezultātu ieviešana}

Pirmo reizi Latvijā pētîta nozīmīga, vājredzību izraisoša pediatrijas oftalmologijas slimība - iedzimta katarakta. Bērnu klīniskās universitātes slimnīcas Acu slimību klīnikā izveidota iedzimtas ārstētas redzei nozīmīgas kataraktas datu bāze, tāpēc iespējams pētīt un pierādīt iedzimtu kataraktu un ar to saistītās acs izmaiņas. Pamatojoties uz klīniskajiem novērojumiem, pētījuma secinājumiem un literatūras izpēti, izveidotas iedzimtas kataraktas diagnostikas un ķirurğiskas korekcijas rekomendācijas ieviešanai praktiskajā bērnu oftalmolog̣ijā.

Laikus veikta kataraktas diagnostika un ārstēšana ir atslēga akluma un vājredzības novēršanai. Tā kā iedzimtas kataraktas atklāšanā un tās cēloņu diagnostikā ir iesaistīti neonatologi, ğimenes ārsti, pediatri, medicīnas g̊enētiķi, oftalmologi, praktiskajās rekomendācijās atspoguļota šo specialistu iesaiste, tās veidotas sadarbojoties ar tiem un saṇemot šo specialistu akceptu. Iedzimtas kataraktas praktiskās rekomendācijas iesniegtas Bērnu Klīniskās Universitātes slimnīcas Kvalitātes dạ̧ā. Tālākais uzdevums ir apspriest un ieviest iedzimtas kataraktas diagnostikas un ārstēšanas rekomendācijas visā valstī. Acs ar kataraktu atklāšana un klīniskā izmeklēšana (sk. nod. Praktiskās rekomendācijas, 1. rekomendāciju) - domāta neonatologiem, gimenes ārstiem, oftalmologiem un pediatrijas oftalmologiem. Klīniskajā ceļā iedzimtas kataraktas diagnostikāa (sk. nod. Praktiskās rekomendācijas, 2. rekomendāciju) iesaistīti pediatrijas oftalmologi, neonatologi un medicīnas ǵenētiķi. Oftalmologam - mikroķirurgam, sadarbojoties ar pediatrijas oftalmologu, būs noderīga 3. rekomendācija - "Iedzimtas kataraktas ķirurǵiskas korekcijas veids atkarībā no pacienta acs aksiālā garuma kataraktas ķirurǵiskas korekcijas laikā”, kas apvienota ar pēcoperācijas medikamentozās terapijas un novērošanas biežuma ieteikumiem (sk. nod. Praktiskās rekomendācijas, 3. rekomendāciju). 


\section{LITERATŪRAS APSKATS}

\subsection{Iedzimtas kataraktas definīcija}

Katarakta ir acs lēcas vai lēcas kapsulas/-u apduļ̧̧̣ošanās, kas nel̦auj gaismai pilnībā vai daļēji nonākt līdz acs tīklenei. Bērnu vecuma katarakta ir lēcas apduļ̧̧̣ojumi, kas izveidojušies intrauterīnā periodā vai bērnībā. Ar terminu "iedzimta katarakta” saprot gan genētiski pārmantotu kataraktu, gan arī kataraktu, kas attīstījusies intrauterīnā periodā ārēju faktoru ietekmē, piem., intrauterīnas infekcijas, metabolas novirzes u.c. rezultātā. Pārmantota iedzimta katarakta var izpausties gan kopš bērna dzimšanas, gan parādīties vēlākā vecumā dzīves pirmo divu gadu desmitu laikā.

\subsection{Iedzimtas kataraktas saistība ar aklumu un vājredzību}

Katarakta zīdaiņa un maza bērna vecumā ne tikai traucē gaismas nonākšanai līdz tīklenei un tāpēc neļauj redzēt, bet, tā kāa redze šai laikā veidojas un attīstās, veido deprivācijas ambliopiju - bērna redze neattīstās neskatīšanās dēḷ. Iedzimta kongenitāla un infantila (pēc kataraktas sākšanās laika klasifikācijas, kas tiks paskaidrota tālāk tekstā) katarakta potenciāli var radīt smagu visa mūža garuma redzes invaliditāti. Apmēram 200000 bērnu pasaulē ir akli neoperētas kataraktas dēḷ, kataraktas ķirurǵijas komplikāciju vai ar kataraktu saistītu citu iedzimtu anomāliju dēḷ [34, 30, 80]. Divpusēja iedzimta katarakta ir visbiežākais potenciāli ārstējamais akluma cēlonis zīdaiṇu vecumā. Iedzimtas kataraktas izraisītas vājredzības un akluma novēršana ir Pasaules Veselības organizācijas un Starptautiskās akluma novēršanas aǵentūras apvienotā projekta "VISION 2020 - Tiesības redzēt" prioritāte [22, 91].

\subsection{Iedzimtas kataraktas incidence un prevalence}

Pārskatot ziṇojumus no jaundzimušo skrīninga programmām vai nacionālajiem iedzimtu anomāliju reǵistriem, var iegūt informāciju par iedzimtas kataraktas biežumu [104]. Ziemel̦amerikas pētījumā, kurā izmantots nacionālo iedzimto anomāliju reǵistrs, iedzimtas kataraktas incidence ir 2,03 uz 10000 dzimušo [9]. Iedzimtas kataraktas incidence Lielbritānijā viena gada vecumā ir 2,49/10 000, palielinoties līdz 3,18/10 000 piecu gadu vecumā un 3,46/10 00015 gadu vecumā, bilaterālas kataraktas incidence bija augstāka nekā vienpusējas 
kataraktas incidence (160/83), pēc dzimuma incidence bija vienāda [99]. Aprēķini liecina, ka iedzimtas kataraktas biežums Austrālijāa ir 2,2/10000 [331], Zviedrijā 4/10 000, Dānijā 2,3/10 000, Francijā 2,2/10 000 [30]. 1997. gadā tika aprēķināts, ka katru gadu pasaulē piedzimst 20 000-40 000 bērnu ar bilaterālu iedzimtu kataraktu, un tās izplatība pasaulē ir 1-4 bērniem uz 10000 [30]. Tāpēc iedzimta katarakta tiek pieskaitīta retām slimībām, kuras raksturo izplatība, kas mazāka par pieciem gadījumiem uz 10000 populācijas [104].

Runājot par iedzimtas kataraktas epidemiologiiskajiem datiem, korektāk un precīzāk būtu runāt par iedzimtas kataraktas biežumu saistībā ar redzes invaliditāti un aklumu, ne tikai atsevišķi par kataraktas kā lēcas stāvokḷa izplatību. Pirmajā variantā, vadoties pēc epidemiologiskajiem datiem, var plānot profilakses stratēǵijas valstī iedzīvotāju līmenī, izprast un aprēķināt ārstēto bērnu un to ǵimeņu daudzumu izvēlēties, kā vislabāk novērtēt "labu" rezultātu [104].

Akluma biežums, ko izraisa iedzimta katarakta vai tās ārstēšanas komplikācijas, attīstības valstīs ir no viena līdz četriem bērniem/10 000 populācijas, salīdzinot ar apmēram 0,10,4/10 000 industrializētajās valstīs [113]. Slimības, kas saistītas ar acs lēcas slimībām, ir otrajā vietā aiz slimībām, kuras saistītas ar tīkleni un kuras ir visbiežākās akluma izraisītājas pasaulē [52].

Iedzimtas un infantilas kataraktas prevalences (izplatības) un incidences (saslimšanas gadījumu biežuma) aprēķinus ietekmē bērnu populācijas kopējā veselība un izdzīvošana, reǵiona sociāli ekonomiskās attīstības stāvoklis, kā arī agrīna redzes un acu traucējumu skrīninga organizācija reǵionā vai valstī [104].

Latvijas statistikas dati par iedzimtas kataraktas biežumu vēl diemžēl ir samērā neprecīzi mūsu pašu ne vienmēr precīzi sniegtās informācijas dēḷ. Slimību profilakses un kontroles centra (SPKC) uzturētajā “Ar noteiktām slimībām slimojošu pacientu reǵistrā” par pacientiem ar iedzimtām anomālijām (sistēma PREDA) pašreiz ir reǵistrēti 74 pacienti ar diagnozi "iedzimta katarakta" (dzimuši no 1992. līdz 2016. gadam). Rēķinot, ka vidēji gadā Latvijā piedzimst 20000 bērnu un 24 gados bijuši 74 pacienti ar iedzimtu kataraktu, perioda prevalence būs aptuveni 1,54 iedzimtas kataraktas gadījumi uz 10000 bērnu [107]. 


\subsection{Acs lēcas un kataraktas veidošanās}

\subsubsection{Acs lēcas anatomija}
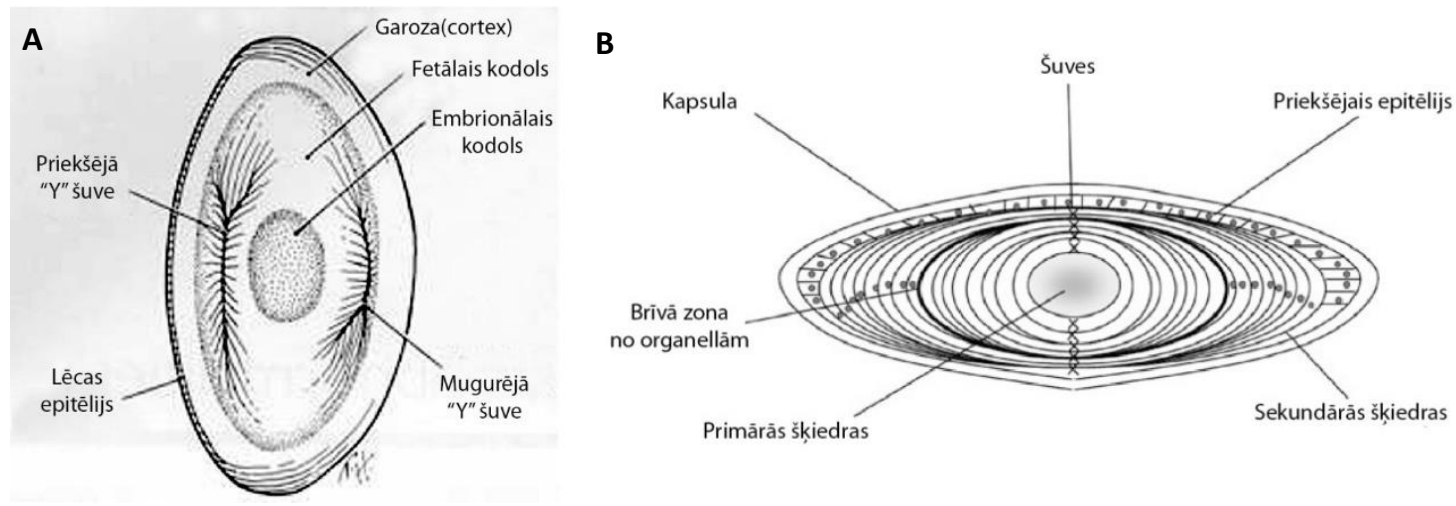

\section{1. att. Acs lēcas anatomija}

A - acs lēcas anatomiskā uzbūve (attēls adaptēts no doc. O. Koroḷovas lekcijas materiāliem);

B - shematiska lēcas diagramma (adaptēta no [36])

Acs lēca ir divpusēji izliekta refrakcijas struktūra, kas atrodas acī starp varavīksneni un stiklveida ķermeni (corpus vitreum), tā ir iekarināta starainajās josliṇās jeb zonulās, kas atiet no starenes (corpus ciliare). Lēcas ekvatoriālais diametrs (ED), bērnam piedzimstot, ir 6,6 mm, priekšēji mugurējais dziļums (PMDz) - 3,5 mm. Bērnam augot, tas palielinās, ED sasniedz 9 mm, PMDz - 5 mm. Lēca sastāv no embrionālā kodola, fetālā kodola un lēcas garozas. Embrionālais kodols attīstās līdz 6. gestācijas nedēḷai, tas ir veidots no primārām lēcas šķiedrām, atrodas centrāli, Y šuvju iekšpusē, ir vizuāli nedaudz tumšāks. Fetālais kodols attīstās no sekundārām lēcas šķiedrām, apņem un iekļauj embrionālo kodolu, izveidojot priekšējo un mugurējo Y šuvi [86]. Izmeklējot kataraktas pacientus ar biomikroskopu, reizēm l̦oti skaidri var izsekot lēcas anatomijai. Nākamajos trijos pievienotajos lēcas biomikroskopijas attēlos var izsekot lēcas garozai sānu griezumā un retroiluminācijā (1.2. attēls A, B), kā arī redzēt iedzimtu lēcas šuvju kataraktas gadījumu (1.2. attēls C). 

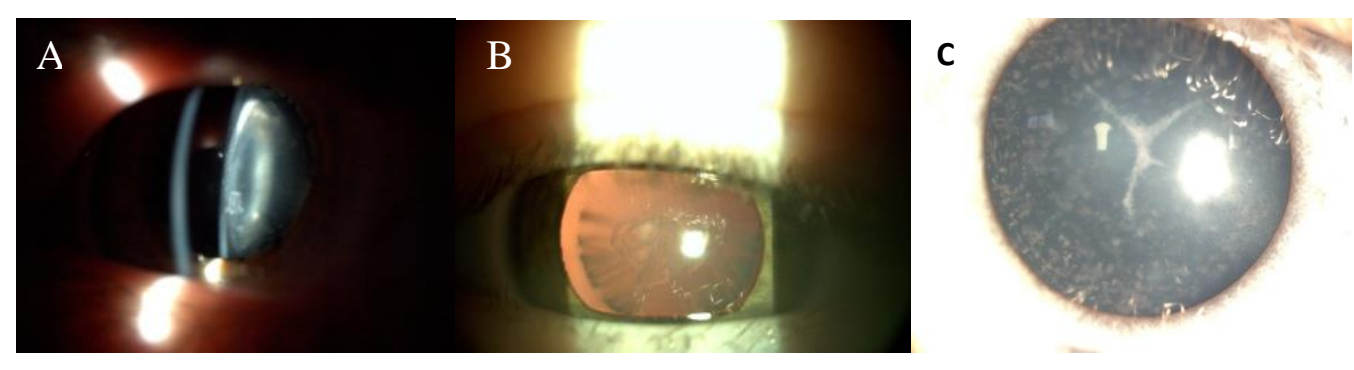

\author{
1.2. att. Acs lēcas biomikroskopiska fotodokumentācija \\ A - iedzimta garozas katarakta sānu biomikroskopiskā griezumā; \\ B - iedzimta garozas katarakta retroiluminācijā; \\ C - šuvju katarakta tiešā iluminācijā (BKUS ASK fotoarhīvs, S. Valeiņas foto)
}

\title{
1.4.2. Acs lēcas embrionālā attīstība
}

Normāla lēca ir caurspīī̄ga; katrs iedzimts vai iegūts lēcas vai tās kapsulas apduḷı̧ojums ir katarakta, un tam ir lielāka vai mazāka ietekme uz redzi vai tās attīstību [51]. Iedzimtas kataraktas morfolog̣iju lielā mērā nosaka lēcas anatomija, laiks un bojājuma veids, kas izraisījis izmainītu lēcas embrionālo attīstību [1]. Acs lēca ir abpusēji izliekta, avaskulāra, caurspīdīga struktūra, ietverta kapsulā, kas ir lēcas epitēlija sekrēta sabiezināta bazāla membrāna [51]. Lēcas embrionālā attīstība ir atkarīga no visas acs embrioǵenēzes. Jau 4. augḷa attīstības nedēḷā parādās divas acs jeb lēcas plakodes. To attīstību ietekmē divi starpsmadzeņu veidotie acu pūšlı. Katram acs pūslim saglabājas saistība ar starpsmadzenēm. Acs pūšlı priekšējā siena iespiežas uz iekšu, pārvēršot acs pūsli par acs kausu (2.3. attēls). Acs kausam ir divas sienas - iekšējā un ārējā. Starp tām izveidojas acs kausa dobums. Acs kauss ir tīklenes aizmetnis. No acs kausa iekšējās sienas attīstās tīklenes neirālā daḷ, bet no ārējās sienas - tīklenes pigmentepitēlijs. Acs kausa un trombocītu augšanas faktora ietekmē no ektodermas ir nodalījušās šūnas, kas veido acs lēcu. Trombocītu augšanas faktoru izstrādā acs varavīksnene un starene (corpus ciliare). Lēcas aizmetnis jeb pūslis aug asimetriski, jo jau 6. attīstības nedēḷā lēcas mugurējās sienas šūnas pie ekvatora izstiepjas un aug uz iekšu, veidojot lēcas primārās šķiedras. Acs kausa ietekmē lēca ieslīd tajā, un tā malas nosedz lēcas malas [23]. 


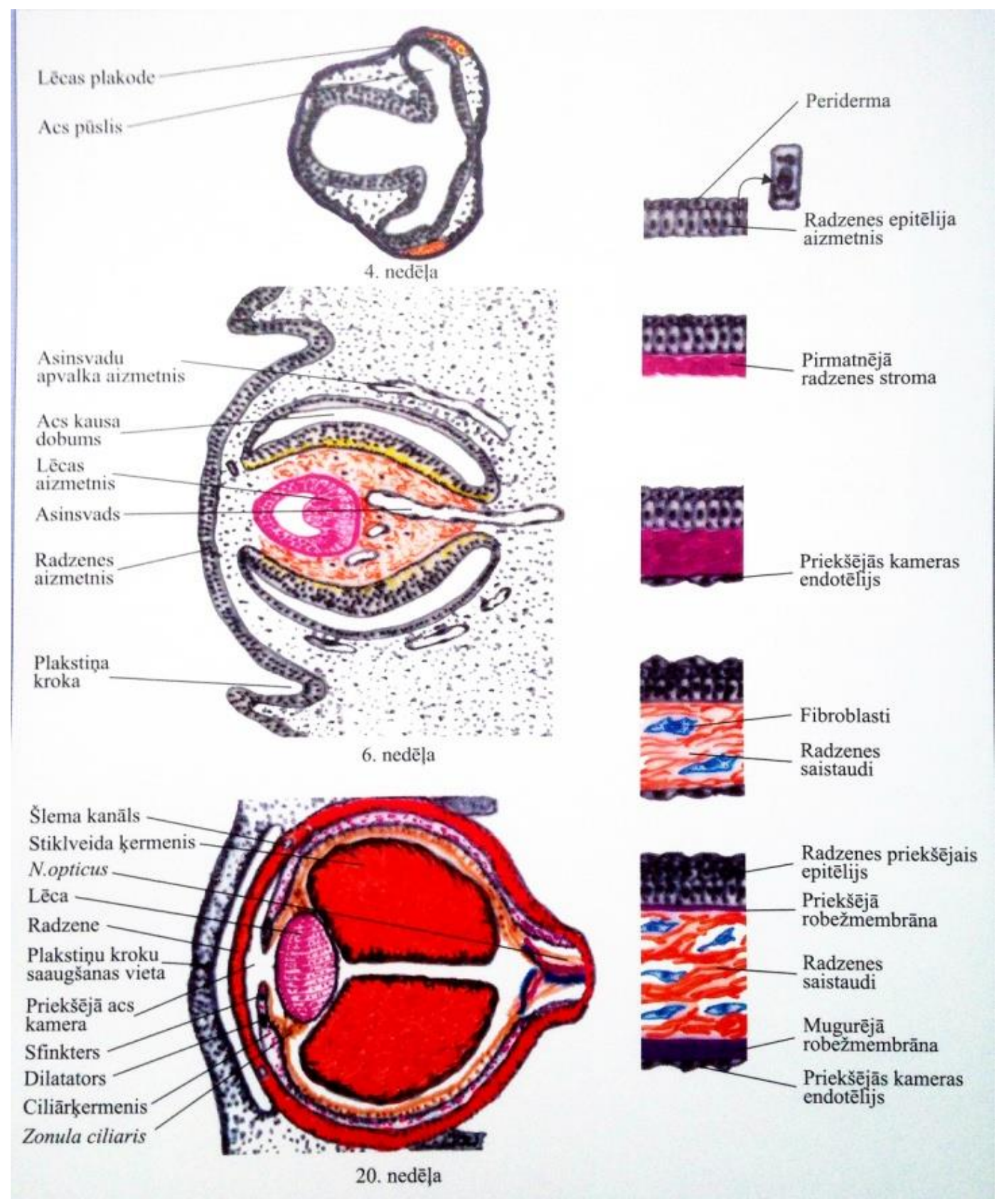

\section{3. att. Acs attīstība [23]}

Primāras lēcu šksiedras veido lēcas embrionālo kodolu, kura diametrs ir 0,35 mm un kurš saglabāsies nemainīgs visu turpmāko dzīvi [74]. Pilnībā attīstītā acī embrionālais kodols ir redzams Y šuvju iekšpusē [76]. 3. mēnesī lēcas priekšējā epitēlija šūnas ekvatorā proliferē un veido lēcas sekundārās šķiedras. To gali savelkoties veido Y burtam līdzīgu priekšējo un mugurējo šuvi. Mugurējā šuve attiecībā pret priekšējo šuvi atrodas apgrieztā stāvoklī. Lēcas sekundārās šķiedras veido lēcas fetālo kodolu. Virs fetālā kodola arī pēc piedzimšanas turpinās lēcas šķiedru veidošanās. Attīstībā esošo lēcu apņem bazālā membrāna, kas veidojas no primārām 
šķiedrām, - tās ir šūnas, kuras diferenciācijas laikā zaudē kodolus, mitohondrijus, endoplazmatisko tīklu un citas organellas (1.4. attēls).

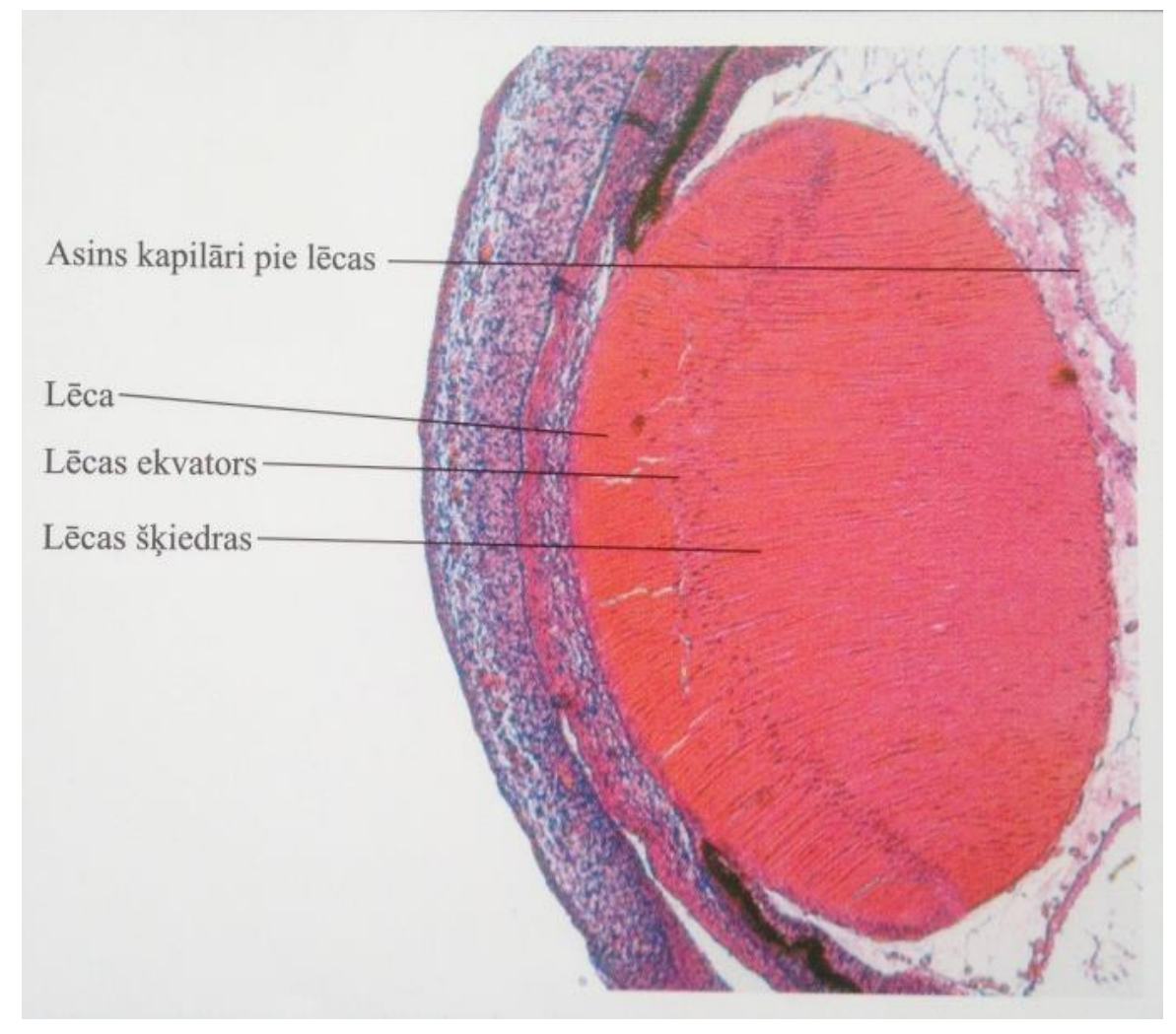

\section{4. att. Acs ābola priekšējā dạ̦a [23]}

Telpā starp stareni (corpus ciliare) un lēcas ekvatoru sabiezē ārpusšūnu matrice, kas veido stiklveida ķermeni (corpus vitreum). Embrionālajā acs ābolā cauri acs spraugai acs kausā ieaug a. hyaloidea, kas sazarojas topošajā stiklveida ķermen̄i, ap lēcu veidojot tunica vasculosa lentis (TVL). TVL ir asinsvadu tīkls, ko no mugurpuses apgādā a. hyaloidea - primārā mugurējā a. ophthalmica, kas nodrošina lēcas barošanu. No priekšpuses apgāde notiek no asinsvadu anastomozēm saistaudu membrānā z̄ilìtes rajonā (membrane pupillaris). Šì membrāna veido tunica vasculosa lentis, kas parādās apmēram 35. attīstības dienā un ir visizteiktākā pēc 65. dienas, regresējot apmēram 85 dienu laikā. Acs lēcas attīstībā būtiska ir caurspīdīgas vides iegūšana. Caurspīdīgumu rada lēcā sintezētie specifiskie olbaltumi - kristalīni [23].

\subsubsection{Acs lēcas attīstības bioloğija}

Lēcas attīstības procesā nepieciešama signālu pārnese starp virsmas ektodermu un optisko pūslīti, lai izveidotu lēcas plakodi (1.5. A att.). Optiskais stiebrs ir modelēts, inducējot PAX2 caur SHH. LHX2 izraisa BMP4 ekspresiju PNR, kas, savukārt, izraisa SOX2 ekspresiju virsmas 
ektodermā; tas izraisa TF ekspresijas kaskādi lēcas plakodē, inducējot lēcas pūslīša veidošanos (1.5. B att.) [29].

Lēcas attīstībā galvenā nozīme ir PAX6 gēnam. Sākotnēji PAX6 darbība aptver visu galvas ektodermu, bet vēlāk TGF $\beta$ signālu rezultātā no dziḷāk lokalizētās kraniālās nervu plāksnītes šūnām tā darbība vērsta uz topošās acs lēcas attīstību Abiniekiem Xenopus novērotā PAX6 gēna nepareiza ekspresija izraisa lēcas ektopiju [137]. PAX6 gēna, MEIS transkripcijas faktoru saimes, kā ar̄̄ BMP7 un FGF signālcel̦i nosaka plakodes lokalizācijas rajonu pirms ektodermas sabiezējuma [64]. Pelēm normālo BMP4 un BMP7 gēnu trūkuma (nulles mutāciju) gadījumā lēca neveidojas. Fgf signālcel̦a pārrāvums izraisa plakodes PAX6 gēna ekspresijas pavājināšanos, kā arī defektus lēcas agrīnajā attīstībā un lēcas bedres invaginācijāa SOX2 (vai SOX1) un PAX6 kopēja piesaiste gēna transkripcijas aktivitātes pastiprinātājiem (enhancer) ir nepieciešama lēcas kristalīna gēna agrīnai ekspresijai. Fox saimes gēns FOXE3 ir PAX6 mērḳa gēns, kura ekspresija notiek topošās lēcas plakodē.

Mutācijas FOXE3 gēnā cilvēkiem un pelēm izraisa afakiju un mikroftalmiju. Indivīdiem ar mutācijām gēnā MAB21/1 lēcas plakodē nenotiek FOXE3 ekspresija, lai gan PAX6 gēns nav skarts. Tas ļauj domāt, ka MAB21/1 aktivācija notiek starp plakodes PAX6 un FOXE3 aktivāciju [64]. Pelēm bez normāliem MAB21/1 gēniem nepietiekamas plakodes invaginācijas dēl veidojas rudimentāras lēcas, ko izraisa FOXE3 nepietiekama ekspresija (PAX6, SOX2 un SIX3 ekspresija ir normāla). MAF saimes galvenie leicīna rāvējslēdzēja (leucinezipper) tipa transkripcijas faktori arī ir iesaistīti lēcas attīstībā, un tos regulē PAX6 gēns. 


\section{Gēnu iesaiste acs lēcas attīstībā}

Lēcas indukcija

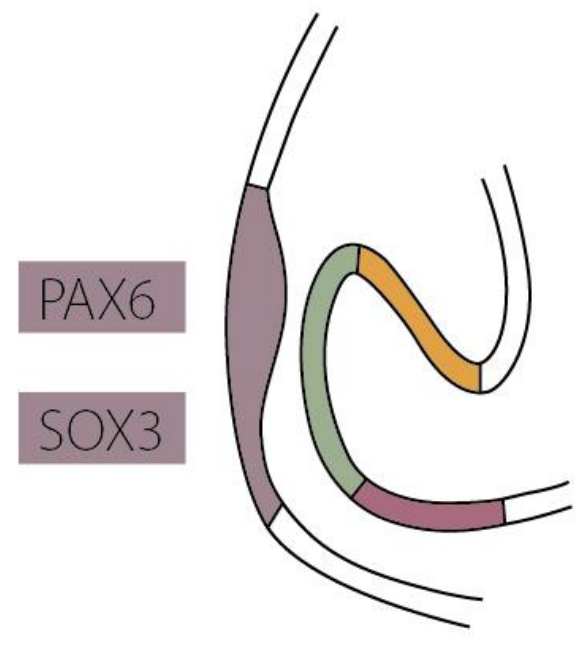

(A)
Lēcas pūslīša veidošanās
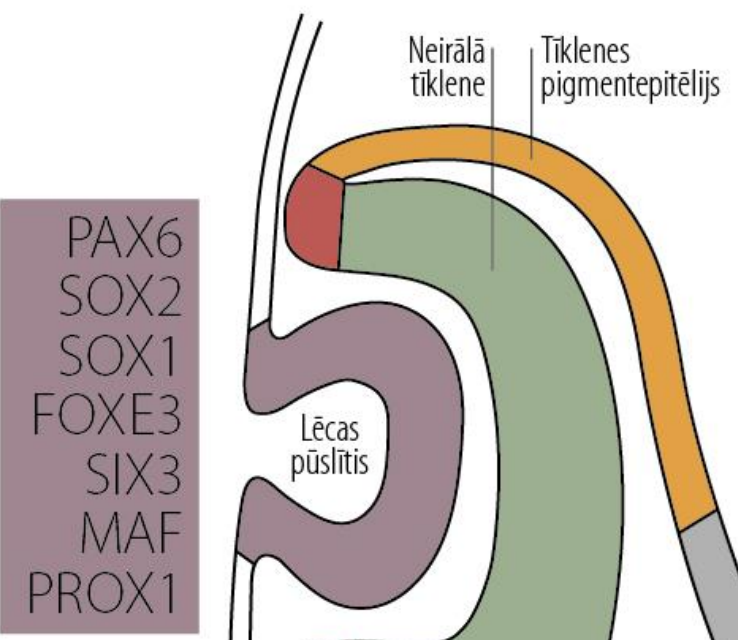
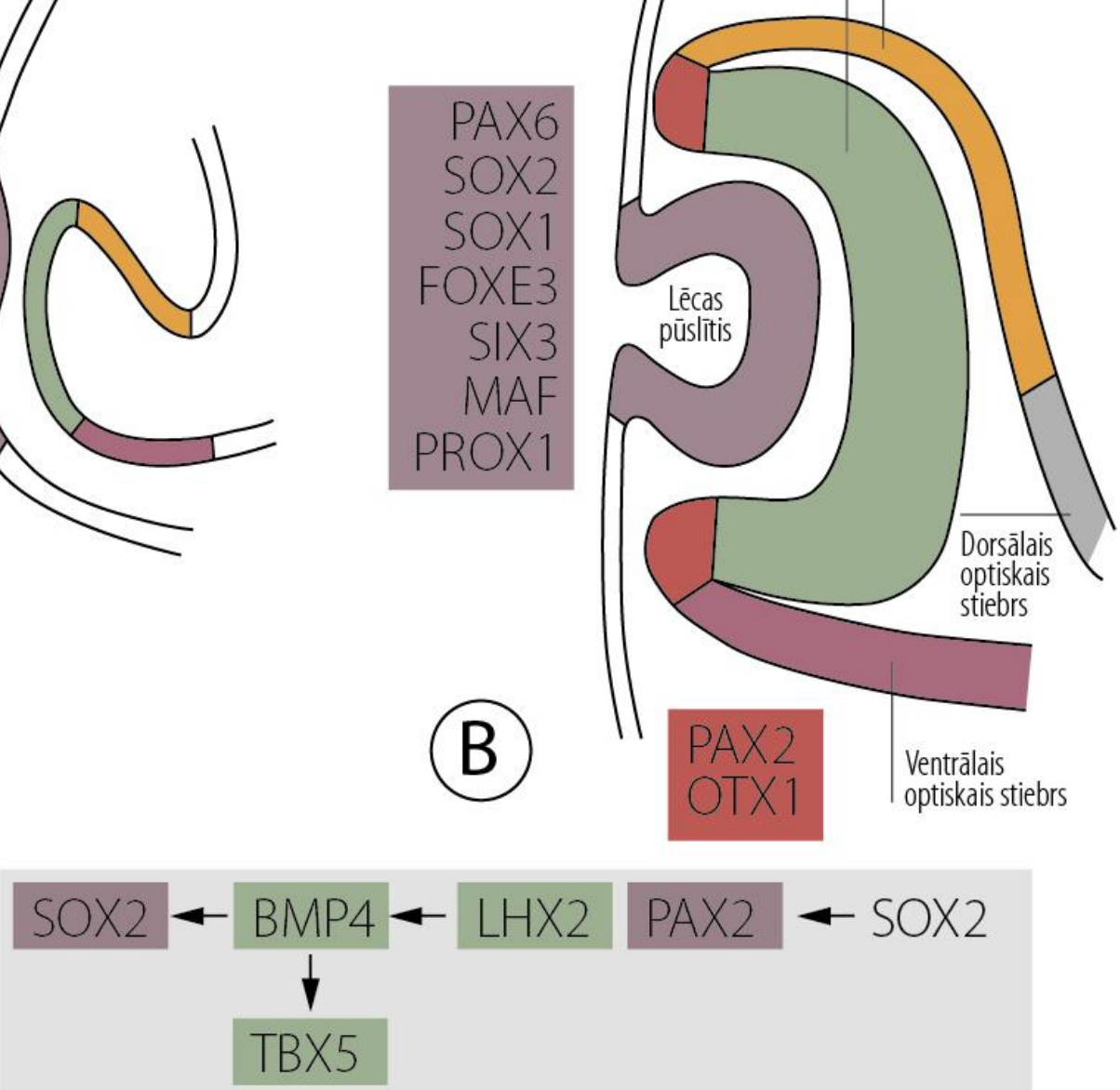

\section{5. att. Lēcas veidošanās (adaptēts no[29]) \\ A - lēcas indukcija ; B - lēcas pūslī̌sa veidošanās}

Kad lēcas pūslītis ir atdalījies no ektodermas virsmas, lēcas šķiedru šūnu diferenciācijai un elongācijai svarīga ir PROX1 gēna ekspresija; PROX1 mutāciju gadījumā lēcas nepolarizējas un nepagarinās, tā veidojot dobas lēcas [125]. PAX6 ekspresija lēcas epitēlijā turpinās līdz vakuolas slēgšanās brīdim, savukārt SOX2 ekspresija pavājinās drīz pēc vakuolas izveidošanās. Šajā laikā lēcā notiek SOX1 ekspresija, primārajās šksiedru šūnās aizstājot SOX2 ekspresiju. Mutācijas SOX1 gēnā pelēm izraisa kataraktu. 


\subsection{Iedzimtas un bērnu vecuma kataraktas klasifikācijas}

Bērnu vecuma jeb pediatriskajai kataraktai ir dažādi klasifikācijas veidi. Iedzimta katarakta procentuāli un skaitliski veido lielāko bērnu vecuma kataraktas gadījumu daḷu. Katrs no klasifikācijas veidiem noteiktā aspektā raksturo lēcas apdulı̧̧̧ojumu. Dažādu autoru pediatriskās oftalmolog̣ijas grāmatās, pārskatos un rakstos klasifikācija nedaudz, tomēr atšķiras. Galvenie klasifikācijas veidi ir šādi:

1) pēc lateralitātes izšksir vienpusējo jeb monolaterālo vai abpusējo jeb bilaterālo kataraktu;

2) redzes prognozei, ārstēšanas veidam un laikam ļoti nozīmīga ir kataraktas morfoloğiskāa klasifikācija, kas raksturo lēcas apdulı̧̧⿻juma veidu [55, 82, 111, 126]. Izšķir kapsulāru, subkapsulāru, nukleāru jeb kodola, kortikālu jeb garozas, lamelāru jeb slāṇainu, suturālu jeb šuvju kataraktu;

3) bērnu vecuma katarakta var būt iedzimta un iegūta. Iegūtā katarakta ir ar noteiktu izcelsmi, to klasificē pēc etiologiijas - izšksir traumatisku kataraktu un kataraktu, kas izveidojusies citu acu slimību, medikamentu vai radiācijas iedarbības rezultātā [47, 126]. Iedzimtā katarakta var būt sporādiska un pārmantota. Iedzimta katarakta tiek pārmantota atbilstoši Mendeḷa likumiem un tiek iedalīta autosomāli dominantā, autosomāli recesīvā un ar X hromosomu saistītā kataraktā. Pārmantotā katarakta tiek grupēta četrās lielās kategorijās: (1) izolēta nesindromiska katarakta; (2) katarakta ar ekstralentikulārām anomālijām; (3) katarakta, kas manifestējas kā viena no pazīmēm multisistēmiskā stāvoklī; (4) katarakta, kas ir iedzimtas metabolisma kḷūdas prezentācija [36];

4) klīniski viena no nozīmīgākajām ir iedzimtās kataraktas klasifikācija pēc kataraktas sākšanās laika (age at onset), izdalot kongenitālo, infantilo vai juvenilo iedzimto kataraktu [126].

Šajā darbā tiek izmantoti trīs kataraktas klasifikācijas veidi- pēc sākšanās laika, pēc lateralitātes un morfolog̣iskā klasifikācija.

\subsubsection{Klasifikācija pēc kataraktas sākšanās laika}

Pēc kataraktas sākšanās laika iedzimta katarakta var būt kongenitāla, infantila un juvenila [126].

Kongenitālu kataraktu diagnosticē jau dzimšanas laikā, tā attīstījusies jau embrionālajā periodā (1.6. A att.). Tā kā kongenitālās kataraktas morfoloǵiskie tipi var būt ļoti dažādi, ne vienmēr katarakta tiek atpazīta un fiksēta, bērnam piedzimstot. To var neieraudzìt un 
nediagnosticēt līdz laikam, kamēr bērnam tiek pamanīts samazināts redzes asums, pelēka zīlīte vai šķielēšana (1.6. B att.).

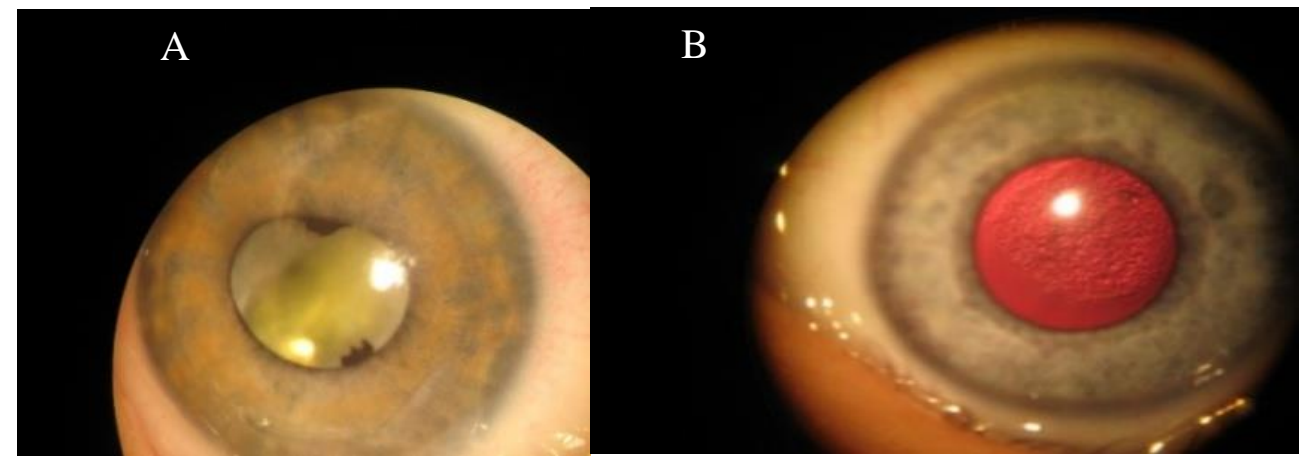

1.6. att. Iedzimta kongenitāla katarakta

(BKUS ASK fotoarhīvs, S. Valeiņas foto)

A - iedzimta kongenitāla difūza/totāla katarakta, diagnosticēta uzreiz pēc dzimšanas;

B - iedzimta kongenitāla mugurējās plātnes katarakta, diagnosticēta viena gada vecumā profilaktiskajā redzes pārbaudē

Infantila katarakta attīstās pirmo divu dzīves gadu laikā (1.7. A un B att.).
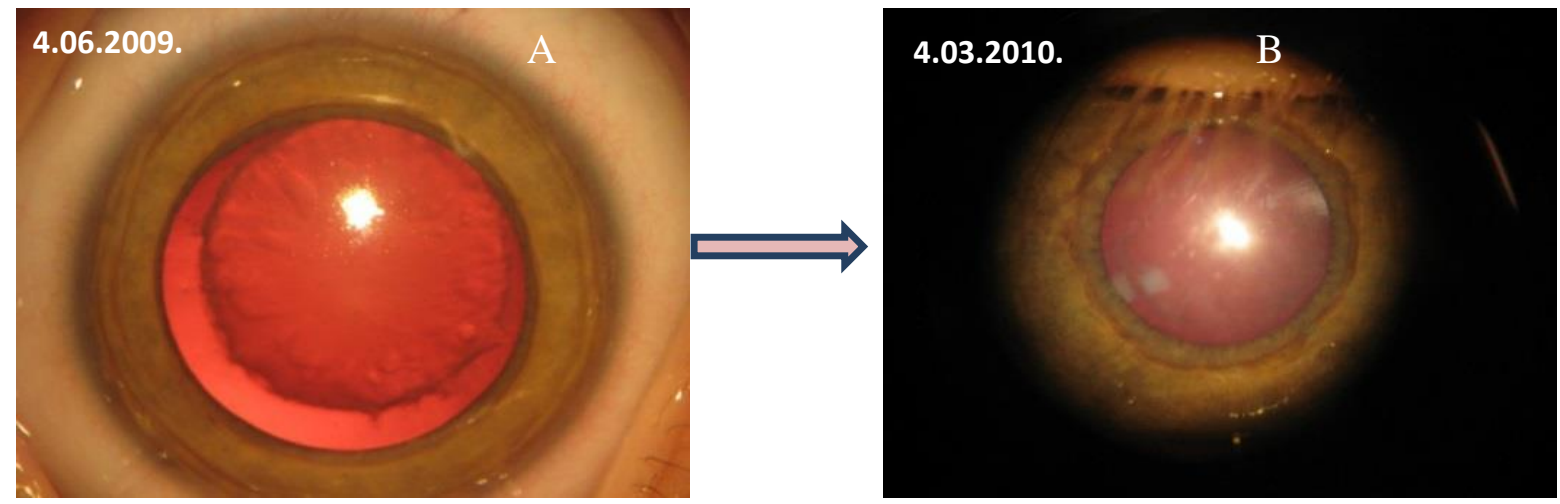

1.7. att. Iedzimta progresējoša infantila kodola katarakta

(BKUS ASK fotoarhīvs, S. Valeiņas foto)

A - Iedzimta infantila kodola katarakta trīs mēnešu vecumā;

B - tā pati infantilā katarakta 12 mēnešu vecumā

Juvenila iedzimta katarakta attīstās un parādās pirmajā un otrajā dzīves gadu desmitā

(1.8. att.). Tai bieži ir autosomāli dominanta pārmantojamība. 


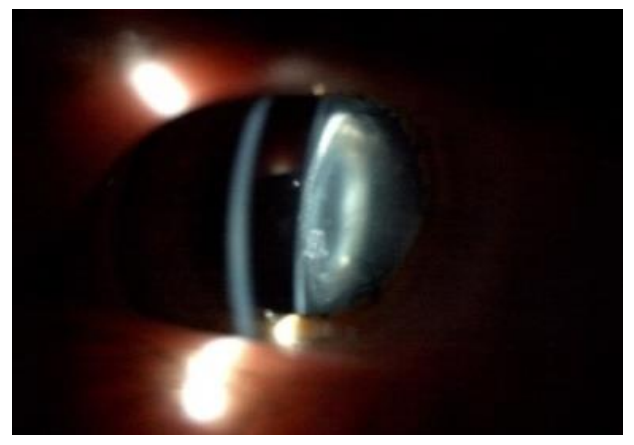

\section{8. att. Juvenila autosomāli dominanti pārmantota progresīva lamelāra katarakta pacientam attīstījusies 14 gadu vecumā \\ (BKUS ASK fotoarhīvs, S. Valeinas foto)}

\subsubsection{Iedzimtas kataraktas morfologija}

Iedzimtas kataraktas morfoloǵija ir ļoti variabla. Lēcas apduļ̧̧̧ojumiem var būt plašs izpausmju un variāciju spektrs, no minimāla, redzei nesvarīga punktveida apduļ̧̣ojuma lēcas priekšèjā kapsulā līdz biezam, totālam apduļ̧̣⿻jumam, kas ietver dažādas lēcas struktūras [1, 55, 70]. Tāpēc kataraktas morfologiskā klasifikācija ir sarežğīta, un dažādi autori piedāvā dažādu līmeņu un veidu morfoloǵisko klasifikāciju [51, 55, 126, 135]. Dažādi speciālisti - operējošs kataraktas ķirurgs, medicīniskās ǵenētikas speciālists vai bērnu oftalmologs - savā darbā izmanto atšķirīgus kataraktas morfolog̣iskos dalījumus un klasifikāciju. Būtiski atšķiras redzei nozīmīgas un redzei nenozīmīgas kataraktas morfoloǵiskais dalījums. Iedzimtas kataraktas morfoloğija ietver un atspoguļo kataraktas veidošanās laiku un iemeslu, uzskatāmi parādot lēcas embrionālo attīstību un anatomiju [1]. Tāpēc kataraktas morfoloğija bieži var dot iespēju noteikt kataraktas etiolog̣iju, kataraktas sākšanās laiku, atsevišķos gadījumos liecina par pārmantojamību. Pēc kataraktas morfologijas var izteikt prognozi bērna redzes attīstībai. Lambert piedāvātā bērnu vecuma kataraktas morfologiskā klasifikācija Hoyt and Taylor "Pediatric Ophthalmology and Strabismus" ceturtajā izdevumā (2013) ietver gan iedalījumu, gan izmaiņu izskaidrojumu [55]. Kanski apvienotajā Clinical Ophthalmology, ko ļoti daudz oftalmologu izmanto kā mācību grāmatu, sniedz līdzīgu, bet nedaudz atšksirīgu klasifikāciju [48]. Pandey un Wilson grāmatā "Pediatric Cataracts Surgery" rekomendē klīnikā bieži lietotu, 1982. gadā modificētu [87] redzei nozīmīgu kataraktas morfologiisko klasifikāciju, kas apstiprināta Parks et al 1993. gadā publicētajā rakstā [90]. 1.1. tabulā apvienotas trīs dažādu avotu morfoloǵiskās klasifikācijas, uzskatāmi parādot kopīgo un atšksirīgo tajās. 
Praksē lietotās dažādu oftalmologu grupu* izstrādātās iedzimtas kataraktas morfoloğiskās klasifikācijas

\begin{tabular}{|c|c|c|}
\hline $\begin{array}{c}\text { Nischal K. no Kanski J. J. } \\
\text { "Clinical } \\
\text { Ophthalmology"[51] }\end{array}$ & $\begin{array}{l}\text { Lambert S. R. no Hoyt G. \& } \\
\text { Taylor D. } 2 \\
\text { "Pediatric Ophthalmology and } \\
\text { Strabismus" [55] }\end{array}$ & $\begin{array}{c}\text { Panday S. K,.Wilson.M. E. no } \\
\text { Wilson M.E. \& Co } \\
\text { "Pediatric Cataracts Surgery" } \\
{[87]}\end{array}$ \\
\hline & Difūza (totāla) & Difūza (totāla) \\
\hline Nukleāra & Nukleāra (fetāla) & Nukleāra \\
\hline Koronāra (supranukleāra) & Kortikāla (garozas) & $\begin{array}{l}\text { Mugurēja (un priekšēja) } \\
\text { subkapsulāra }\end{array}$ \\
\hline Lamelāra & & Lamelāra \\
\hline & $\begin{array}{l}\text { Persistējošā fetālā vaskularizācija } \\
\text { (PHPV) }\end{array}$ & $\begin{array}{l}\text { Persistējošais hiperplastiskais } \\
\text { primārais vitreus (PHPV) }\end{array}$ \\
\hline Zilā punkta (blue dot) & & \\
\hline Šuvju & & \\
\hline Centrāla "ellas piliena" & & \\
\hline Membranoza & & \\
\hline Priekšēja polāra & & Priekšēja polāra \\
\hline Mugurēja polāra & $\begin{array}{l}\text { Izolēta mugurējās kapsulas plāksne } \\
\text { (mugurēja polāra) }\end{array}$ & Mugurēja polāra \\
\hline & Mugurējais lentiglobus & Mugurējais lentiglobus \\
\hline
\end{tabular}

* Adaptēts no [51, 55, 87].

Mūsu pētîjumā tiek izmantota šāda iedzimtas kataraktas morfologisiskā klasifikācija:

1) totālu difūzu kataraktu var diagnosticēt, jau bērnam piedzimstot, vai tā var veidoties vēlākā periodā, kad dažādi kataraktas tipi, piemēram, lamelāra, mugurēja polāra, var attīstīties līdz totālam difūzam apduḷksojumam [87] (1.9. att.);

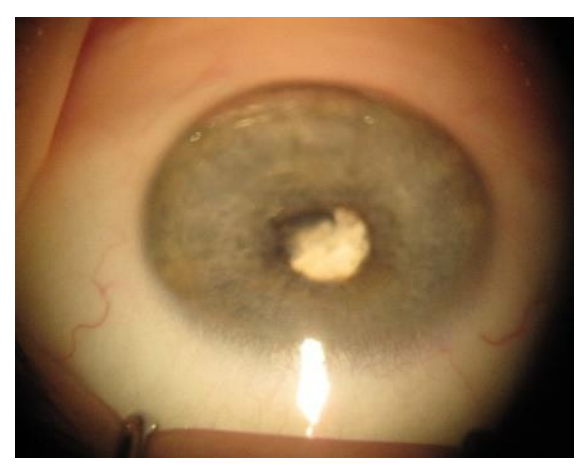

1.9. att. Totāla / difūza kongenitāla katarakta, saistīta ar lēcas masu kalcifikāciju un mugurējo sinehiju (BKUS ASK fotoarhīvs, S. Valeiņas foto) 
2) lamelāra jeb slāṇaina katarakta sākumā ir blāvs, puscaurspīdīgs lēni progresējošs apdulı̧̧̧⿻jums 5-6 mm diametrā, tajā tiek iesaistīti lēcas slāṇi, kas apņem fetālo lēcas kodolu (1.10. att.). Parasti katarakta ir bilaterāla, var būt asimetriska. Lamelāra katarakta biežāk sākas vēlākā laika periodā. Tā kā kritiskajā redzes attīstības laikā lamelāra katarakta neaizsedz vizuālo asi, redzes prognoze ir labāka nekā iedzimtiem blīviem kodola apduļ̧̧̣ojumiem [87];

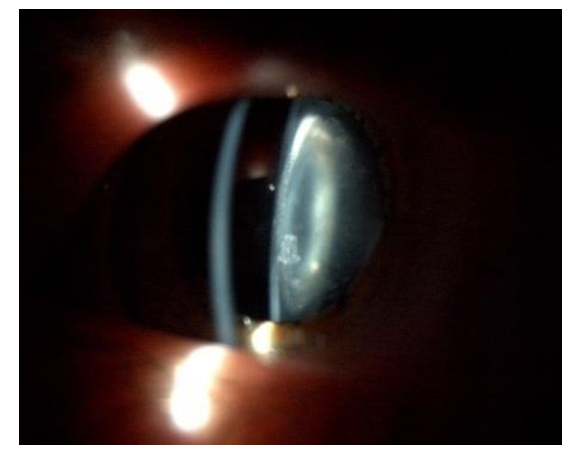

1.10. att. Lamelāra katarakta (BKUS ASK fotoarhīvs, S. Valeiņas foto)

3) nukleārā jeb kodola katarakta ir kā balts centrāls apduļ̧̧̧ojums apmēram 3,5 mm diametrā starp priekšējo un mugurējo "Y" šuvi, kas, bērnam augot, var progresēt - izplatīties uz apkārtējām lēcas masām. Kodola katarakta var būt saistīta ar mugurējās kapsulas plātni. Kā asociētus simptomus var novērot mikroftalmu un sliktu varavīksnenes dilatāciju. Ja šī katarakta netiek laikus ārstēta ķirurǵiski, tā izraisa deprivācijas ambliopiju [87,130] (1.11. A un B att.);

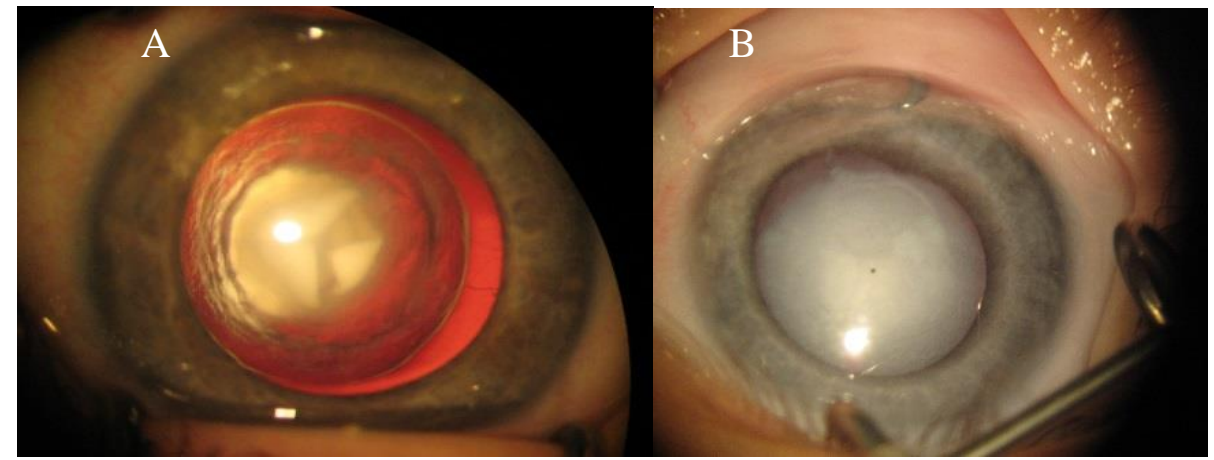

1.11. A un B att. Iedzimta nukleāra jeb kodola katarakta

(BKUS ASK fotoarhīvs, S. Valeiņas foto)

A - kongenitāla fetālā kodola katarakta;

B - infantila progresīva kodola katarakta

4) mugurējā polārā katarakta, tostarp mugurējās kapsulas plātnes katarakta, parasti ir sporādiska, izolēta, parasti tā attīstās no dzimšanas. Lēcas izmaiņas sākas mugurējā kapsulā, 
kas, iespējams, ir vājāka $a$. hyaloidea projekcijas vietā. Apdulı̧kojums var progresēt, pieaugot intralentikulārajam spiedienam, ir iespējams spontāns mugurējās kapsulas plīsums. Dažreiz tā kombinējas ar mugurējo lentiglobusu [87] (1.12. A un B att.);

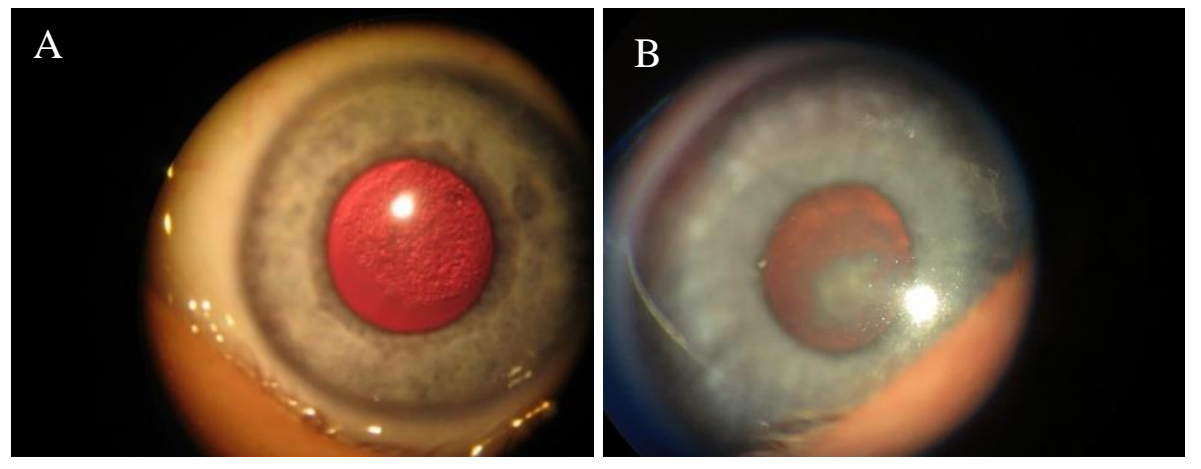

1.12. A un B att. Iedzimta mugurējās plātnes un mugurējā polārā katarakta (BKUS ASK fotoarhīvs, S. Valeiņas foto)

A - puscaurspīdīga iedzimta mugurējās plātnes katarakta;

B - fetālā kodola katarakta, kas saistīta ar mugurējo polāro kataraktu

5) kortikālā jeb garozas katarakta neietver lēcas kodolu, veidojas vēlākā bērna vecumā, var būt saistīta ar mugurējās kapsulas plātni (1.13. att.).

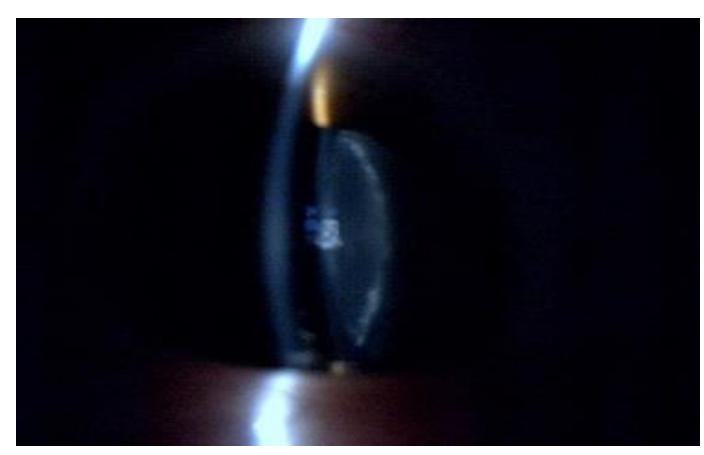

1.13. att. Kortikāla jeb garozas katarakta (BKUS ASK fotoarhīvs, S. Valeiņas foto)

Mūsu pêtījumā lịoti retās izplatības dēl netiks analizēti šādi iedzimtas kataraktas morfologiskie tipi:

6) mugurējais lentikonuss vai lentiglobuss veidojas no lēcas mugurējās kapsulas palielināta izliekuma, kurā var būt vai nebūt mugurējās kapsulas defekts. Tā rezultātā tiek mainīta lēcas refrakcija, var veidoties izteikts lēcas astigmatisms [55];

7) persistējošā fetālā vaskularizācija (pastāvīga aug̣̦a asinsvadu sistēma) vai persistentais hiperplastiskais primārais vitreus (PHPV) (1.14. att). Tos veido kāds no šeit minētajiem 
morfologiiskajiem variantiem vai šo variantu kombinācija: retrolentāla membrāna ar vai bez redzamiem asinsvadiem, persistējoši hialoidāli asinsvadi vai izstiepti starenes (corpus ciliare) izaugumi [55] ;

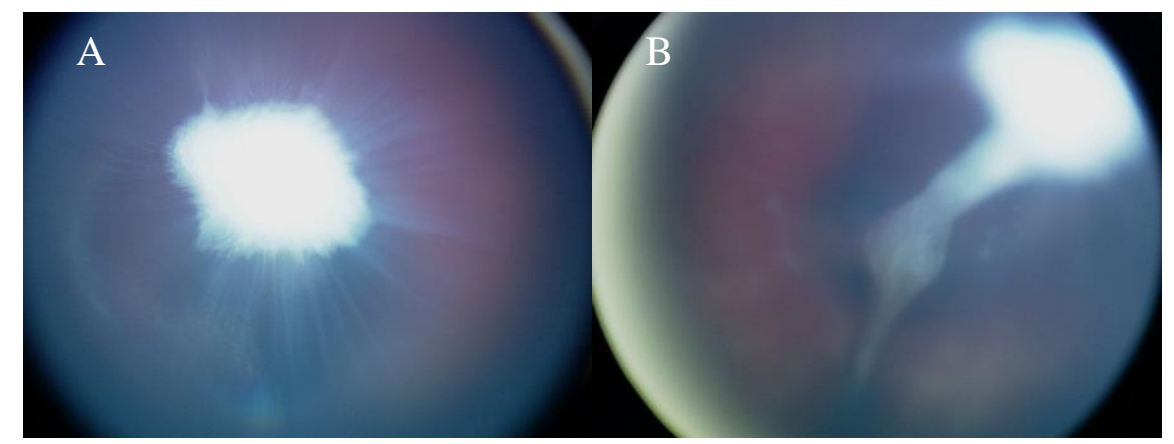

1.14. A un B att. Persistentais hiperplastiskais primārais vitreus (PHPV) (BKUS ASK fotoarhīvs, S. Valeiņas RET CAM attēli)

8) priekšējā polārā katarakta parasti ir bilaterāla, pārmantota un vizuāli nenozīmīga. Parasti tā ir kā mazs balts punkts priekšējās kapsulas centrā. Tā diametrs ir $1 \mathrm{~mm}$ vai mazāk, tā parasti neprogresē. Viens no priekšējās polārās kataraktas veidiem ir arī piramidāla katarakta, daḷa no tās var iesniegties priekšējā kamerā un ļoti retos gadījumos saplūst ar radzeni.

9) priekšējais lentikonuss ir retāk sastopams par mugurējo, tas bieži ir asociēts ar Alporta sindromu. Priekšējā lentikonusa gadījumā katarakta parasti ir vēlīna atrade [87].

Lai noteiktu kataraktas morfoloǵisko tipu, vecākus bērnus izmeklē ar biomikroskopu. Bērnus vecumā līdz 3 gadiem, kā arī bērnus, ar kuriem grūti veidot kontaktu un veikt nepieciešamos izmeklējumus, izmeklē vispārējā anestēzijā ar operācijas mikroskopu un rokas biomikroskopu. Izmeklēšanas laikā izdara fotodokumentāciju [80]. Randomizētā multicentru klīniskā pētījumā "Zīdaiņu afakijas ārstēšanas pētījums" (Infant Aphakia Treatment Study (IATS)) kataraktas operācijas laikā tika uzṇemta videofilma. Operētās acs kataraktas morfologiiskais tips tika noteikts, trīs neatkarīgiem ekspertiem analizējot uzfilmētos materiālus un vienojoties par apduļ̧̧̧ojuma konfigurāciju un novietojumu [130].

\subsection{Iedzimtas kataraktas diagnostika}

\subsubsection{Sārtā refleksa tests}

Tā kā gan vienpusējas, gan abpusējas iedzimtas kataraktas gadījumos ir iespējama redzes zaudēšana, l̦oti svarīgi ir laikus veikt kataraktas diagnostiku un ārstēšanu. Iedzimtas kataraktas atklāšanai ir pieejama skrīninga metode - sārtā refleksa tests. Spīdinot ar oftalmoskopu vesela 
bērna acīs, būs redzams sārts gaismas reflekss, ko veido atspīdums no acs dz̄̄slenes. Kataraktas gadījumā gaisma neatspīd uz dzīslenes un "sārto refleksu" neredz [47]. Acu "sārtā refleksa" pārbaude ar oftalmoskopu tiek ieteikta kā standartizmeklēšanas metode dzemdību namā uzreiz pēc dzimšanas, kā arī visās vesela bērna pediatriskās attīstības pārbaudēs [55]. Puscaurspīdīgas kataraktas atklāšanā pieejama un salīdzinoši vienkārša metode ir arī retinoskopija. Ar retinoskopiju tiek noteikta acs refrakcija, novērtējot līdzi ejošu vai pretēji ejošu retinoskopa ēnu dažādu acs refrakciju gadījumos. Lēcas daļējas apduļ̧̣⿻šanās gadījumos, kad ar oftalmoskopu redz it kā sarkanu refleksu, retinoskopijas reflekss var kḷūt mazāk izšķirams un grūti nosakāms. Tas liek domāt par lēcas apduļ̧̧̣ojumu un veikt padziļinātu izmeklēšanu. Retinoskopiju veic, esot šaurai un/vai paplašinātai acu zīlītei ar neintensīvu gaismu [80].

Bērna redzes sistēma attīstās pirmajās dz̄ives nedēḷās, unilaterāla vai bilaterāla deprivācija iedzimtas totālas un nukleāras kataraktas gadījumos rada atšķirīgas strukturālas izmaiņas corpus geniculatum laterale un cortex striate. Ja deprivācija unilaterālas kataraktas gadījumā ir ilgāka par 6 nedēḷām vai bilaterālas kataraktas gadījumā ilgāka par 10 nedēḷām, minētās izmaiṇas kḷūst neatgriezeniskas [70]. Tāpēc laikus veikta kataraktas diagnostika un ārstēšana ir atslēga akluma novēršanai. Iedzimtas kataraktas atklāšana ir galvenais uzdevums visām zīdaiņu redzes skrīninga programmām, kas eksistē gandrīz visās Eiropas Savienības valstīs [103]. Lielbritānijas Veselības ministrijas noteikumos ir iekḷauta sarkanā refleksa pārbaude bērniem uzreiz pēc dzimšanas un sešu nedēḷu vecumā [104]. Bērniem ar pozitīvu iedzimtu kataraktu ǵimenes anamnēzē vai sistēmiskām diagnozēm, par kurām ir zināms, ka tās var asociēties ar kongenitālu/infantilu kataraktu, ir ieteicama oftalmologa pārbaude iedzimtas kataraktas izslēgšanai. Valstīs, kurās nav zīdaiņu redzes vai acu anomāliju skrīninga programma, iedzimtas kataraktas diagnostika notiek vēlāk. Tas nosaka biežāku iespējamo vājredzību un aklumu iedzimtu kataraktu gadījumos [134]. Laikus veikta kataraktas diagnostika ir viens no katras valsts veselības aprūpes kvalitātes indikatoriem. Latvijā līdz 1990. gadam noteiktos vecumos bija noteiktas redzes un acu profilaktiskās apskates, kas it kā sniedza labu pārredzamību un deva labas agrīnas diagnostikas iespējas. Profilaktiskās redzes apskates bija noteiktas viena, trīs un 6 gadu vecumā. Taču, skatoties no šodienas un Eiropas skata punkta, šīs profilaktiskās apskates ir ekonomiski neizdevīgas. Dažādu iemeslu dēl tikai aptuveni 30\% bērnu Latvijā ir bijuši uz acu profilaktiskajām apskatēm. . Apskates veic oftalmologi, kuru izglīî̄iā valsts iegulda izteikti lielus līdzekḷus, nodrošinot augstāko medicīnisko izglītību (6 studiju gadi) un medicīnas specializāciju (4 studiju gadi). Tā kā iedzimta katarakta bieži attīstās no dzimšanas, diagnostika viena gada 
vecumā ir stipri novēlota, redzes deprivācija un ambliopija jau būs neatgriezeniska, bērnam arī pēc izcili veiktas kataraktas ķirurǵiskas korekcijas veidosies vājredzība.

Latvijas Ministru kabineta 2006. gada 4. aprīḷa Nr. 265 noteikumu 93. pielikumā iekḷauta fiziskās un garīgās attīstības novērtēšanas lapa bērna vecumā no 1 nedēḷas līdz 5 gadiem [73].

1.2. tabulā var izsekot acu sārtā refleksa pārbaudei ar oftalmoskopu vairākos zīdaiņa vecumos, ko iesaka Latvijas Ministru kabineta noteikumi [66].

1.2. tabula

Sārtā refleksa pārbaudes ieteikums fiziskās un garīgās attīstības novērtēšanas lapā bērniem vecumā no 1 nedēḷas līdz 5 gadiem

\begin{tabular}{|c|c|c|c|c|}
\hline Bērna vecums & & 1 nedēḷa & 3 nedēlas & 1 mēnesis \\
\hline $\begin{array}{l}\text { Klīniskā } \\
\text { izmeklēšana. } \\
\text { Vecumam } \\
\text { atbilstošu } \\
\text { klīnisko } \\
\text { izmeklēšanu } \\
\text { ieteicams veikt } \\
\text { katrā vizītē }\end{array}$ & & $\begin{array}{l}\text { Fizikāla visu } \\
\text { orgānu sistēmu } \\
\text { izmeklēšana. } \\
\text { Īpaša } \\
\text { izmeklēšana: acu } \\
\text { sārtā refleksa } \\
\text { pārbaude ar } \\
\text { oftalmokopu }\end{array}$ & $\begin{array}{l}\text { Fizikāla visu } \\
\text { orgānu sistēmu } \\
\text { izmeklēšana. } \\
\text { İpaša } \\
\text { izmeklēšana: }\end{array}$ & $\begin{array}{l}\text { Fizikāla visu } \\
\text { orgānu sistēmu } \\
\text { izmeklēšana. } \\
\text { İpaša izmeklēšana: } \\
\text { radzenes gaismas } \\
\text { reflekss }\end{array}$ \\
\hline Problēmas, plāni & & & $\begin{array}{l}\text { Acu sārtā } \\
\text { refleksa } \\
\text { pārbaude ar } \\
\text { oftalmokopu, ja } \\
\text { nav veikta } \\
\text { iepriekš }\end{array}$ & $\begin{array}{l}\text { Acu sārtā refleksa } \\
\text { pārbaude ar } \\
\text { oftalmokopu, ja } \\
\text { nav veikta } \\
\text { iepriekš }\end{array}$ \\
\hline Bērna vecums & 2 mēneši & 3 mēneši & 4 mēneši & 6 mēneši \\
\hline $\begin{array}{l}\text { Klīniskā } \\
\text { izmeklēšana. } \\
\text { Vecumam } \\
\text { atbilstošu } \\
\text { klīnisko } \\
\text { izmeklēšanu } \\
\text { ieteicams veikt } \\
\text { katrā vizītē }\end{array}$ & $\begin{array}{l}\text { Fizikāla visu } \\
\text { orgānu sistēmu } \\
\text { izmeklēšana }\end{array}$ & $\begin{array}{l}\text { Fizikāla visu } \\
\text { orgānu sistēmu } \\
\text { izmeklēšana. } \\
\text { Īpaša } \\
\text { izmeklēšana: acu } \\
\text { sārtā refleksa } \\
\text { pārbaude ar } \\
\text { oftalmokopu }\end{array}$ & $\begin{array}{l}\text { Fizikāla visu } \\
\text { orgānu sistēmu } \\
\text { izmeklēšana }\end{array}$ & $\begin{array}{l}\text { Fizikāla visu } \\
\text { orgānu sistēmu } \\
\text { izmeklěšana. } \\
\text { Īpaša izmeklēšana: } \\
\text { acu sārtā refleksa } \\
\text { pārbaude ar } \\
\text { oftalmokopu. } \\
\text { Radzenes gaismas } \\
\text { reflekss/ } \\
\text { škielēšanas } \\
\text { pārbaude ar } \\
\text { aizklāšsnas testu }\end{array}$ \\
\hline
\end{tabular}

2013. gadā visā Latvijā tika aptaujāts 121 medicīnas speciālists - 17 neonatologi, 9 pediatri, 60 ǵimenes ārsti, 35 ǵimenes ārsti pediatri, kuru aprūpē bija ietverti bērni, kas veido 22\% no kopējā 2012. gadā jaundzimušo bērnu skaita visā Latvijas teritorijā. Aptaujā atklājās, ka 60\% no aptaujātajiem sārtā refleksa testu neveic. 32,23\% atzīmē, ka viṇiem nav skaidra sārtā 
refleksa pārbaudes nozīmība, 43,8\% norāda, ka viņiem nav prasmju ieraudzīt patologiju un to atšķirt no normas [119]. Kopš 2013. gada ir pagājuši 5 gadi. Ģimenes ārstu rezidentūras programmā ir iekḷauta lekcija par acu sārtā refleksa testa nozīmību. Esam uzstājušies par šo tēmu Latvijas pediatru, neonatologu un gimenes ārstu asociāciju konferencēs. Lai saprastu, vai esam pagājuši soli uz priekšu, 2019. gada janvārī, februārī tika veikta atkārtota aptauja un pētījums, kura rezultāti tika publicēti un prezentēti Eiropas Pediatrijas oftalmoloǵijas 2019. gada konferencē Rīgā 01.06.2019.

\subsubsection{Anamnēze, fotoalbuma izvērtēšana, biomikroskopija vecākiem}

Kataraktas pacienta izmeklēšana zīdaiņa un bērna vecumā ir visaptveroša padziḷināta pacienta vispārējā un oftalmoloǵiskā stāvokḷa izvērtēšana, sagatavojot slēdzienu par tālāko neķirurǵisko vai ķirurǵisko ārstēšanas taktiku. Bērna izmeklēšana sākas ar detalizētu anamnēzi, ieskaitot ǵimenes anamnēzi, prenatālo anamnēzi, ieskaitot mātes lietotos medikamentus un saslimšanas ar drudzi un izsitumiem bērna gestācijas laikā [80]. Izvērtējot dzimšanas anamnēzi, jāpievērš uzmanība dzimšanas svaram. Dāṇu pētījuma autori ziņo, ka bērniem ar dzimšanas svaru zem 2000 g 10,9 reizes biežāk novērotas bilaterālas idiopātiskas infantilas kataraktas [42]. Rūpīgi jāizvērtē bērna attīstības vēsture, lai izslēgtu metabolu un sistēmisku saslimšanu iemeslus. Svarīgs ir lēcas apduļ̧̣⿻šanās sākums, lateralitāte un progresēšana. Ja vecāki nav droši par apduļ̧̣⿻juma sākšanās laiku, viņiem lūdz paņemt līdzi uz vizīti ǵimenes fotogrāfiju albumu [80]. Sevišķi, ja vecāks bērns tiek prezentēts ar vienpusēju pirmreizēji atrastu kataraktu, sarkanā refleksa uzman̄̄ga aplūkošana vecās fotogrāfijās var dot atbildi, cik ilgu laiku no redzei kritiskā perioda lēcas apduļ̧̧̣ojums ir traucējis redzes attīstībai [110]. Spraugas lampas izmeklēšana bērna vecākiem, brāliem un māsām pēc cikloplēgijas var atklāt agrāk nediagnosticētas nelielas lēcas izmaiņas bērna ğimenes locekļiem. Pārmantotas ar X hromosomu saistītas kataraktas gadījumos vīriešiem būs novērojama nozīmīga, redzei bīstama katarakta, bet vīrieša mātei var atklāt nelielu, nenozīmīgu lēcas apduļ̧̣ojumu. Piemēram, izmeklējot māti zēnam ar pierādītu Louva (Lowe) sindromu, viņai tika atrasta nenozīmīga punktveida katarakta [66].

\subsubsection{Fiksācija un redzes asuma novērtēšana}

Redzes asuma noteikšana visu vecumu bērniem ir liels izaicinājums. Vecākiem bērniem, kas labprāt sadarbojas, redzes asumu nosaka ar optotipiem. Sākumā tiek izmantoti E burti, priekšmetu attēli, vēlāk burti, cipari, citas pieejamās redzes tabulas. Optotipu izvēle ir atkarīga no bērna vecuma un intelektuālās attīstības. Lamelāras un mugurējas subkapsulāras kataraktas 
gadījumos redzes asums izmeklēšanas joslā ar parastu apgaismojumu liekas normāls vai pieņemams, bet spilgtuma pārbaudē (Glare testing) redzes asums samazinās par divām vai vairākām līnijām. Tas atklāj bērnam iespējamās dienas gaismas grūtības [80]. Vienmēr jāatceras par bērnu starpā diezgan izplatīto mānī̌sanos - vienas acs sliktākas redzes gadījumos viṇi samērā bieži noskatās tabulu ar otro aci.

Pacientam jāizmeklē arī acu zìlīšu reakcijas. Relatīvais aferentais pupilārais deficīts un nistagms kataraktas diagnosticēšanas brīdī liecina par sliktu redzes prognozi [71].

Bērniem līdz 3 gadu vecumam vai bērniem ar apgrūtinātu kontaktu un sadarbību noteikt redzes asumu ar standarta izmeklēšanas metodēm nebūs iespējams. Tomēr bērna redzes spējas tad var noteikt gan vērojot vienas un otras acs fiksāciju, gan salīdzinot bērna iebildumus vienas vai otras acs aizklāšanas gadījumos. Precīzāk bērna redze tiek novērtēta ar izvēles skatīšanās testiem (Cardiff tests, Teller tests). Ja tiek novērota slikti attīstīta fiksācija, kas var liecināt par redzes traucējumu, tumšā telpā ar tiešo oftalmoskopiju esot šaurai un paplašinātai acs zīlītei veic sārtā refleksa testu vai neintensīvu retinoskopiju, tādējādi objektīvi novērtējot acs lēcas caurredzamību, [80]. Ja ir aizdomas, ka bērnam varētu būt šķielēšana, jācenšas novērtēt bērna redzes raksturu un stereoredzi. Ja šksielēšana ir labi saskatāma, pēc iespējām ar Hiršberga testu, Krimska testu un prizmu aizklāšanas testu nosaka šķielēšanas leņķa veidu un lielumu. Stereoredzi mēra ar stereotestiem. Binokulāro redzi un stereoredzi cenšas noteikt un atzīmēt gan tuvumā, gan tālumā [80].

\subsubsection{Acs refrakcija, kontaktkorekcijas vai IOL stipruma aprēķini, IOL mērķa refrakcija}

Ja apdulı̧̧̧ojums ir nepilna apjoma vai intensitātes, tiek mērīta acs refrakcija. Tas tiek darīts ar retinoskopiju un autorefraktometriju pilnā cikloplēgijā (divas reizes ar 5 minūšu laika starpību pilinot katrā acī 1\% Cyclopentolate šķīdumu, pēc tam gaidot 30-40 minūtes) [55]. Kataraktas operācijas nepieciešamības gadījumā, gatavojoties afakiju koriǵēt ar kontaktkorekciju vai intraokulāru lēcu, tiek veikta autokeratometrija un acs priekšēji mugurējās ass garuma noteikšana ar ultrasonogrāfijas $A$ scan kontaktmetodi vai imersijas metodi [55, 80, 127]. Bērniem līdz triju gadu vecumam un/vai bērniem, kas nesadarbojas, mērījumi tiek veikti vispārējā anestēzijā. Intraokulāro lēcu stipruma aprēksināšanai mērījumus var ievadīt dažādās intraokulāro lēcu (IOL) aprēķināšanas programmās un tehnoloǵijās. IOL aprēķināšanai bērna vecumā izmanto SRK-T, SRKT-II, Hoffer-Q un Holliday formulas [2, 70]. Vairākos pētījumos pierādīts, ka IOL 
aprēķina formulas ir mazāk precīzas zīdaiņiem, kas ir mazāk nekā 36 mēnešus veci, un tiem, kuriem acs aksiālais garums ir mazāks nekā 20 mm [2, 70, 117].

Afakija vai pseidofakija zīdaiņa vecumā pēc lēcas ekstrakcijas iedzimtas kataraktas gadījumos izjauc normālu acs emetropizāciju, rezultātā veidojas liela miopiska acs refrakcijas novirze. Miopiskā novirze var sasniegt 10 un vairāk dioptrijas, un parasti tā atbilst logaritmiskai līknei [78]. 1994. gadā McClatchey aprakstīja gadījumu, kurā 20 gadus vecam pacientam bilaterālā lamelārā katarakta bija izoperēta viena gada vecumā. Pacienta acs refrakcija pēc lensektomijas viena gada vecumā bija +15,5 D labajā acī un +15 D kreisajā acī. 20 gadu vecumā acs refrakcija bija miopizējusies līdz $+2,38$ D labajā acī un +5,75 D kreisajā acī. Negaidīti lielā miopiskā novirze lika domāt, ka intraokulāras lēcas implantācijas gadījumā, ja mērķa refrakcija būtu bijusi emetropija, pacientam būtu izveidojusies izteikta miopija [77]. Pēc š̄ gadījuma McClatchey et al. pētīja lielu grupu bērnu ar afakiju. Šis pētījums kḷuva par bāzi mērḳētai hipermetropai refrakcijai pēc IOL implantācijas bērniem [78]. Vienā no pirmajiem lielajiem multicentru pētījumiem par acīm ar pseidofakiju McClatchey et al. demonstrē, ka acīs ar pseidofakiju ir nedaudz mazāks refrakcijas augšanas ātrums nekā acīs ar afakiju [79]. Tomēr vairāki citi autori apraksta ar̄̄ emetropas mērķa refrakcija ieguvumus, implantējot intraokulāru lēcu bērniem agrīnā vecumā [75, 77, 108]. Intraokulāro lēcu (IOL) mērķa stipruma izvēle iedzimtas kataraktas ārstēšanā atspoguḷojas kā divas dažādas pēcoperācijas refrakcijas kḷūdas ārstēšanas taktikas.

Vēlamās hipermetropijas lieluma izvēle atkarīga no bērna vecuma kataraktas ekstrakcijas un IOL implantācijas laikā. Paredzamās refrakcijas izvēlei un precizitātei ir liela nozīme nevēlamas refrakcijas kḷūdas ieguvē vēlākā bērna un pieaugušā vecumā. Ir daudz pētījumu, kas tieši vai netieši pētījuši iegūstamās pēcoperācijas refrakcijas lielumu, mainību un ietekmējošos faktorus pēc pediatriskas kataraktas ekstrakcijas un intraokulāras lēcas implantācijas. Šo pētījumu mērķi ir bijuši acs aksiālā garuma izmaiņu novērtējums, miopiskās novirzes lieluma un izmaiņu izpēte, refrakcijas kḷūdas lielumi un mainība acīm ar afakiju un pseidofakiju [piemēram: 5, 20, $57]$.

\subsubsection{Acs biomikroskopija, intraokulārā spiediena mērīšana}

Lēcas morfologiija tiek analizēta, veicot biomikroskopiju vairākos palielinājumos - 20D, 24D, 40D. Tiek noteikts apduļ̧̧̣ojuma lielums, lokalizācija, blīvums, kapsulu izmaiņas, piemēram, mugurējās kapsulas defekts, un citas saistītas priekšējā segmenta attīstības anomālijas [80, 111]. Zīdaiņa vecuma bērniem biomikroskopija tiek veikta vispārējā anestēzijā ar operācijas 
mikroskopu un rokas biomikroskopu. Gan pirms, gan pēc kataraktas operācijas tiek mērīts intraokulārais spiediens, izmantojot vienu vai vairākas pieejamās intraokulārā spiediena mērīšanas metodes. Intraokulārā spiediena mērīšana bērniem līdz trīs gadu vecumam un bērniem, kas nesadarbojas, ir sarežǵīta un bieži neobjektīva izmeklēšanas metode [71, 80]. Ja ir atklājies paaugstināts acu spiediens, tad ar vienu mērījumu nepietiek, ir jāveic vairāki mērījumi, ja iespējams, jāizmanto cita mērīšanas metode. Mērot intraokulāro acs spiedienu, jāṇem vērā arī radzenes centrālais biezums un citi izmeklējumi (datorizētie redzes lauki, redzes nerva vizuālais izskats) [12]. Praksē ir pieejama aplanācijas tonometrija (ar Goldmana tonometru, ar Pērkinsa tonometru), I Care tonometrija, Keeler gaisa tonometrija, Maklahova tonometrija, Tonopen tonometrija [80, 111]. Dažādi autori ir salīdzinājuši atšķirīgu tonometrijas metožu iegūtos mērījumus. Pēdējos gados bērnu oftalmologi vairākos rakstos un grāmatās pierāda I Care tonometrijas priekšrocības intraokulārā spiediena mērīšanai zīdaiņa un bērna vecumos [40, 80]. IOS pediatrijas praksē var būt l̦oti atkarīgs no pacienta sadarbības. Stress, ko rada ierīce, kas pieskaras radzenei, var izraisīt pacienta raudāšanu, kura provocē Valsalva mēǵinājumu, palielinot sistēmisko venozo spiedienu un IOS. Tāpēc, ja ir aizdomas par sekundāru glaukomu, papildus rekomendē izmeklēšanu veikt vispārējā anestēzijā [83].

Lai atklātu saistītās okulārās anomālijas, piemēram, persistējošo fetālo vaskularizāciju, samazināta izmēra radzeni (microcornea) un/vai samazināta izmēra acs ābolu (microphthalmia), jāmēra radzenes horizontālais diametrs (laikā dzimušiem jaundzimušajiem normā tas ir 9,9 mm, 12 mēnešu vecumā - 11,1 mm). Jāveic priekšèjā segmenta izmeklēšana un starenes (corpus ciliare) izvērtēšana. Jāveic acs ābola mugurējā segmenta izmeklēšana. Mazs radzenes un acs izmērs un iestiepti starenes izaugumi (processus ciliares) var liecināt par persistējošiem fetāliem asinsvadiem un persistējošo fetālo vaskularizāciju un tās rezultātā izveidojušos iedzimtu kataraktu [80], piemēram, sk. 1.15. attēlu.

\subsubsection{Fundus oculi izvērtēšana, ultrasonogrāfija, acs aksiālā garuma mērīšanas metodes}

Turpinot izmeklēšanu, jāveic fundus oculi un redzes nerva diska apskate (ja iespējams) ar netiešo un tiešo oftalmoskopiju. Ja kataraktas blīvuma dēḷ nav iespējams apskatīt fundus oculi, tiek veikta $B$ scan ultrasonogrāfija $[55,80,111,126]$. Ar $B$ scan vēlams izmērīt arī acs aksiālo garumu caur bērna plakstiņu. Kaut arī šis izmērs nebūs tik precīzs kā acs aksiālā garuma mērījums ar $A$ scan biometriju, tas pēc operācijas noderēs aptuvenai acs augšanas novērtēšanai [80]. Tomēr, kā jau minējām 1.6.4. nodạ̧ā, aprakstot intraokulāras lēcas mērķa refrakcijas aprēķinus, akurāta biometrija ar A scan metodi ir nozīmīga, lai iegūtu vēlamo refraktīvo 
iznākumu un samazinātu nevēlamu, ilglaicīgu ametropiju [70]. "Infant Aphakia treatment study" tika salīdzināta acs aksiālā garuma biometrija ar kontakta $A$ scan metodi un ar imersijas A scan metodi, secinot, ka imersijas A scan metode acs aksiālā garuma mērǐšanai ir precīzāka [122]. Pētījumā tika atzīmēts, ka acs aksiālā garuma izvērtēšanu veic sertificēts acs ultrasonogrāfijas speciālists. Kā pētījuma ierobežojums tika atzīmēta $A$ scan mērījumu kvalitātes variabilitāte. Divām trešdaļām pacientu abu acu aksiālais garums tika mērīts ar imersijas A scan metodi, kamēr viena trešdaļa acu tika mērītas ar aplanācijas jeb kontakta A scan metodi. Salīdzinot imersijas un kontaktbiometrijas mērījumus, tika konstatêts, ka iegūtie acs aksiālā garuma mērījumi, izmantojot kontaktmetodi, vidēji bija par 0,27 mm īsāki, nekā izmantojot imersijas metodi. Par iemeslu tika atzīta radzenes kompresija mērǐšnas laikā [62].

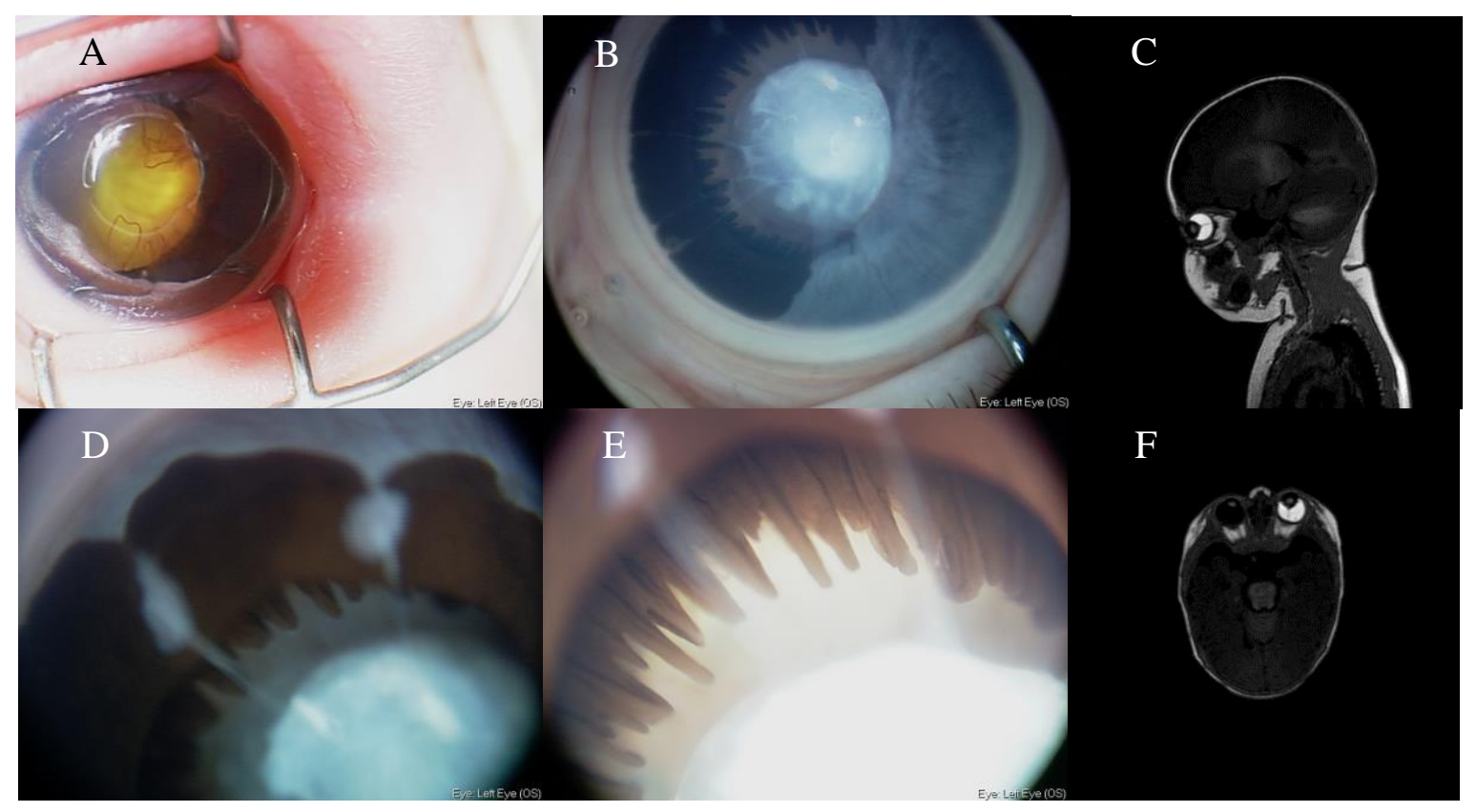

1.15. A, B, C, D, E, F att. Persistējošā fetālā vaskularizācija kombinācijāa ar kataraktu (BKUS ASK fotoarhīvs, S. Valeiņas foto, BKUS Radiolog̣ijas nodaḷas fotoarhīvs)

A, B, C, D - RET-CAM attēli; C, F - MRI attēli 


\subsubsection{Laboratoriskie izmeklējumi}

Vairums (60\%) abpusējo un vienpusējo pediatrisko kataraktu ir idiopātiskas [68], vairums vienpusējo kataraktu ir idiopātiskas, nepārmantotas, nesaistītas ar sistēmiskām slimībām [80]. Pamatojoties uz antenatālo anamnēzi, ǵimenes anamnēzi un kataraktas tipu, dažos gadījumos var būt vajadzīgi laboratoriskie izmeklējumi $[42,68,80]$. Ja bērnam ir pozitīva antenatālā anamnēze, kas liecina par infekciju, ja bērnam papildus iedzimtām vai iedzimtai kataraktai ir arī mikrocefālija, kurlums, sirds anomālija vai/un attīstības aizture, būtu nepieciešams veikt TORCHS analīzes - noteikt antivielas pret Varicella, Herpes simplex, toksoplazmozes, rubella un sifilisa ierosinātājiem [3, 98, 100]. Bilaterālas kataraktas gadījumiem, lai precizētu situāciju, ir izstrādāti speciāli ieteikumi [80]:

1) citādi vesels zīdainis - jāizslēdz galaktozēmija un TORCHS;

2) citādi vesels mazbērns (1-3 gadi) - jāizslēdz galaktokināzes deficīts;

3) zīdainis ar dzelti, kas neattīstās, - jāizslēdz galaktozēmija [8];

4) nevesels zīdainis vai mazbērns, piemēram, bērns ar vienlaikus esošu iedzimtu glaukomu, hipotoniju un attīstības aizturi - jāizslēdz okulocerebrorenālais sindroms (Louva (Lowe) sindroms) [66];

5) specifiskiem stāvokḷiem nepieciešamas specifiskas analīzes (kalcijs, fosfors, glikoze) $[81,97]$.

Šos izmeklējumus nozīmē pēc bērna sistēmiskas pediatriskās izmeklēšanas kopā ar ārstējošo pediatru. Vienpusējas pediatriskas kataraktas gadījumos nekad nedrīkst aizmirst arī par traumas iespējamību [80].

\subsection{8. Ģenētiskais novērtējums}

Klīnicistiem, sevišşi Austrumeiropā, kur ǵenētiskā izmeklēšana daudzās valstīs uz vietas nav iespējama apgrūtinātās pieejamības un lielo izmaksu dēḷ, lēmums par vienas vai otras ǵenētiskās analīzes vajadzību iedzimtas kataraktas pacientiem bieži ir sarežğīts. Ģenētiskas izcelsmes katarakta veido 8-29\% no visiem iedzimtas kataraktas gadījumiem [80]. Lielākā daļa no tām pārmantojas autosomāli dominanti [45]. Kataraktai ir iespējams arī autosomāli recesīvs un ar X hromosomu saistīts pārmantošanas veids [15, 32]. Autosomāli dominanti pārmantotai kataraktai ir labi dokumentēta klīniskā un ǵenētiskā heterogenitāte [32]. Vairāk nekā 40 dažādi gēni un dažādi lokusi ir identificēti saistībā ar iedzimtu kataraktu [45]. Gēnu mutācijas, kas ir atbildīgas par lēcas caurspīdības saglabāšanu, piemēram, kristalīna (crystalline) un koneksīna 
(connexin) gēnu mutācijas, ir visbiežāk aprakstītas saistībā ar nesindromāli pārmantotas kataraktas etioloğiju [32, 45].

Mutācijas $\alpha$ kristalīna gēnā mēdz izraisīt nukleāru, lamelāru, zonulāru vai mugurēju polāru kataraktu. CRYAA gēna mutācija izraisa iedzimtu kataraktu, kas ir asociēta ar mikroradzeni (microcornea). Dažādu mutāciju klīniskajās izpausmēs bieži tiek novērota fenotipiska daudzveidība [34]. Attīstību nosakošo gēnu PAX6, FOXE3, PITX3 un MAF mutācijas izraisa acs priekšējā segmenta iedzimtas anomālijas, kas bieži saistītas arī ar iedzimtu kataraktu [19]. Priekšējā polārā katarakta ar vai bez aniridijas bieži saistīta ar PAX6 gēna mutācijām. Mugurējo polāro kataraktu pārsvarā izraisa PITX3 gēna mutācijas [19]. Atsevišķi jāmin gēni, kas atbildīgi par sindromālu kataraktu, - piemēram, OCRL gēna mutācijas izraisa Louva (Lowe) sindromu [66], GALK117 gēna mutācijas - galaktozēmiju [15].

\subsection{Iedzimtas kataraktas ārstēšana}

\subsubsection{Neķirurğiska ārstēšana}

Pediatriskās kataraktas ķirurǵiskas korekcijas indikācijas nosaka lēcas apduļ̧̣ojuma intensitāte, lokalizācija un apduļ̧̧̣ojuma paredzamā ietekme uz redzes attīstību. Perifēri

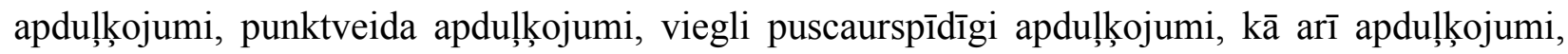
kuru diametrs ir mazāks par $3 \mathrm{~mm}$, bieži tiek tikai novēroti un, ja nepieciešams, - ārstēti ar refrakcijas kḷūdas korekciju un otras acs aizklāšanu [80, 126]. Ilgstoši novērojot 184 acis ar puscaurspīdīgu kataraktu (36\% mugurējās puscaurspīdīgas, 18\% nukleāras), tika konstatēts, ka apdulı̧̧⿻jumi progresēja un attīstījās līdz ķirurğiskas operācijas nepieciešamībai tikai 11\% (21 acī) [18]. Pēc pieciem gadiem šiem pacientiem labāk koriǵētais redzes asums (VA) bija attīstījies līdz 20/38 (vidējais pacienta novērošanas ilgums 5,1 gads). Salīdzinoši pacientiem, kam katarakta neprogresēja, labāk koriğētais VA bija 20/28 (vidējais pacienta novērošanas ilgums 6,1 gads). Šeit gan jāmin, ka pētījumā bija iekḷauti gan iedzimtas kataraktas, gan bērnu vecuma kataraktas gadījumi, kas attīstās vēlākajā, ne kritiskajā redzes attīstības laikā (steroīdu izraisītas kataraktas 28\%) [18]. Noteikt lēcas apduļ̧̧̣ojuma maksimālo lielumu, intensitāti un novietojumu, kas neizraisīs ambliopijas veidošanos, klīnicistiem ir liels izaicinājums. Foster et al. apraksta subjektīvo un objektīvo metodi, kā novērtēt zīdaiņu kataraktas smaguma pakāpi, kas var noderēt kā vadlīnijas agrīnas ķirurğiskas ārstēšanas pamatošanai vai nogaidīšanai. Kataraktas subjektīvā iedalīšana pakāpēs pamatojas uz kataraktas morfologiju, blīvumu un novietojumu, izmantojot 11 punktu (0-10) skalu. Jo augstāks skaitlis, jo lielāka iespēja, ka apdulķ̧ojums traucēs redzei (1.3. tab.). Dinamiskas kataraktas gadījumos izmantoja diapazonu, lai atspoguḷotu kataraktas sākotnējo 
stāvokli un progresēšanas galīgo stāvokli. Biomikroskopiskas (Nikon Zoom FS-3) krāsainas acs lēcas fotogrāfijas retroiluminācijā un tiešajā iluminācijā tika ieskenētas un objektīvi matemātiski analizētas, izmantojot speciālu programmu [31].

Šì pētījuma rezultāti liecina, ka būtu lietderīgi izmantot gan subjektīvus, gan objektīvus novērtējumus, lai veiksmīgi reǵistrētu bērna kataraktas veidu un prognozētu tās ietekmi uz redzes attīstību. Infantilas kataraktas graduēšanas jeb šķirošanas skalas izmantošana attīsta praktiskas iemaṇas kataraktas izvērtēšanai, lai izšksirtu, kurā brīd̄̄ nepieciešams iejaukties ķirurǵiski. Kataraktu, kam piešksirta 1.-4. pakāpe, var atstāt in situ un periodiski novērot [31]. Taču katarakta, kurai piešksirta 5. un augstāka pakāpe, ideālā gadījumā būtu jāoperē agrīnā vecumā, lai samazinātu deprivācijas ambliopijas veidošanos redzei kritiskajā attīstības periodā [70, 71]. Ikdienas klīnikas dzīvē, diagnosticējot dažādas morfoloǵijas un novietojuma iedzimtu kataraktu, pētījumā atspoguḷotā subjektīvās šķirošanas (graduēšanas) tabula katrā noteiktā laika posmā palīdz izşķirties par lēmumu ārstēt kataraktu neķirurǵiski vai ķirurǵiski un paredzēt kataraktas atšksirīgo iespējamo dinamiku (1.3. tab.). 
Pētījumā izmeklēto deviņu infantilās kataraktas morfoloğisko tipu klīniskās detaḷas

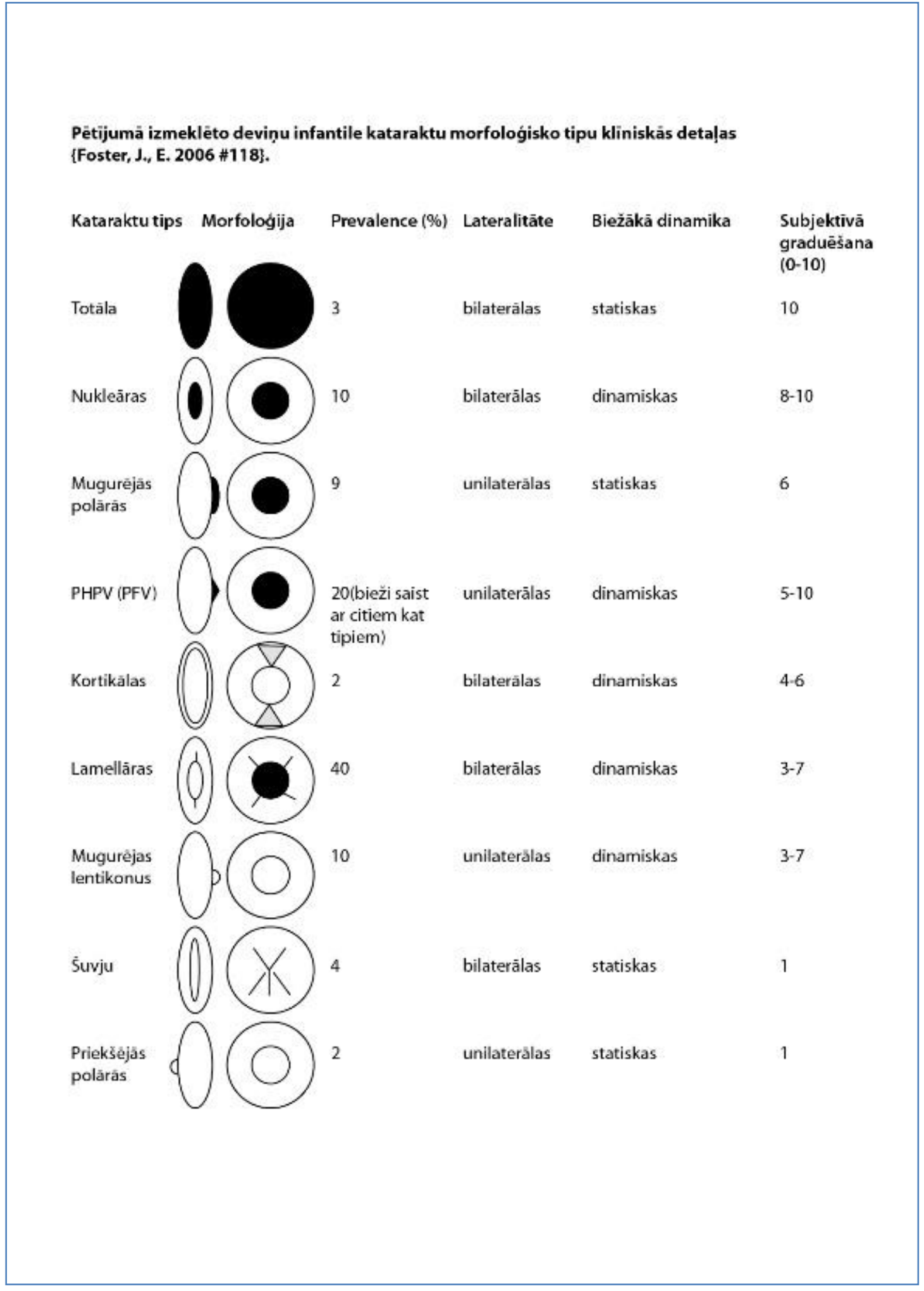

* Adaptèta no Foster, J., E., Abadi RV, Muldoon M, Lloyd IC. Grading infantile cataracts. Ophthal.Physiol.Opt. 2006;26:372-379. [31] 


\subsection{2. Ķirurǵiska ārstēšana}

Pirms iedzimtas kataraktas ķirurğiskas ārstēšanas jāatbild uz šādiem jautājumiem:

1) kad būtu optimāli veikt ķirurǵisko korekciju;

2) kādu ķirurǵgiskas korekcijas tehniku izvēlēties;

3) kādā veidā pēc lēcas ekstrakcijas tiks veikta trūkstošā refraktīvā apjoma korekcija kā kontaktkorekcija vai kā intraokulāra korekcija (IOL)?

Ja izvēlas intraokulāro korekciju, kāda būs intraokulārās mākslīgās lēcas mērķa refrakcijas taktika - emetropas vai hipermetropas IOL implantācija?

Lai izprastu optimālo laiku iedzimtas kataraktas ķirurğiskai ārstēšanai, nepieciešams izprast bērna redzes attīstību.

\section{Redzes attīstības sensitīvais periods}

Piedzimstot bērna redze nav izveidojusies. Redzes attīstība ir saistīta ar zīdaiṇa acu un smadzeņu augšanu, attīstību un nobriešanu. Acs aug, un tīklenes ganglijšūnu aksoni atrod ceļu ārā no acs, caur redzes nervu un redzes neirālajiem ceḷiem tie sasniedz smadzeņu redzes garozu. Zīdainim augot un nobriestot, redzes spējas arvien palielinās, sasniedzot pieauguša cilvēka redzi raksturojošos lielumus. Slimība vai iedzimta anomālija acī vai redzes sistēmā var samazināt vai nedot iespējas redzei attīstīties, līdz ar to bērns var kļūt vājredzīgs vai neredzīgs ar vienu vai abām acīm [33]. Redzes attīstībai raksturīgi trīs periodi - latentais, sensitīvais un kritiskais.

\section{Latentais jeb subkortikālais periods}

Neonatālā redzes sistēma ir anatomiski, fiziolog̣iski un funkcionāli nenobriedusi visos līmeņos - sākot no acs līdz smadzeņu garozai, vidussmadzenēm un smadzeņu tilta acu kustību kontroles centriem [26]. Ļoti agrīnā neonatālā periodā nenobriedusī redzes sistēma balstās uz subkortikāliem redzes ceḷiem. Latentā jeb subkortikālā perioda laikā īslaicīgs redzes traucējums neietekmē redzes attīstību un redzes gala rezultātu. Elston un Timms pētīja septiņus bērnus ar aferentiem (centrālas tīklenes hemorāǵijas, plaksta hematoma) un eferentiem (III un IV nerva parēzes) redzes sistēmas traucējumiem uzreiz pēc dzimšanas [26]. Dokumentētie redzes sistēmas bojājumi spontāni labojās bērna dzīves pirmo nedēḷu laikā. Sekojoša normāla redzes un binokulārās redzes attīstība pierāda latento periodu zīdaiņa redzes attīstībā. Šis periods ilgst aptuveni sešas nedēlas. To novēro no bērna dzimšanas līdz sensitīvā redzes attīstības perioda sākumam [26]. Definējot sensitīvā perioda sākuma laiku, iespējams uz pierādījumiem balstīti 
definēt iedzimtu patoloǵiju - arī redzei nozīmīgas iedzimtas kataraktas - ķirurǵiskās korekcijas ieteicamos laikus [70, 71]. Vienpusējas kataraktas ekstrakcija pirmajās 4-6 nedēḷās un bilaterālas kataraktas ķirurǵiska korekcija pirmajās 8-10 dzīves nedēḷās var samazināt stimulu deprivācijas ambliopijas attīstību, līdz ar to arī šksielēšanas un nistagma attīstību [10]. Pareiza optiskā rehabilitācija un oklūziju terapija, ja nepieciešams, dos pozitīvu ietekmi redzes un binokulārās redzes attīstībai $[55,59,71]$.

\section{Iedzimtas kataraktas ķirurğiskās korekcijas tehnika - lensektomija, priekšējā vitrektomija}

Iedzimtas kataraktas ķirurǵiska korekcija ietver lensektomiju vai lensektomiju un priekšējo vitrektomiju [55]. Dažos pēdējos gadu desmitos lensektomijas tehnika ir izteikti pilnveidojusies. Apvienojot automātisku mehānisku lensektomijas/vitrektomijas tehniku, noņemot, cik iespējams, daudz un pietiekami lēcas kapsulu, var novērst sekundāru redzes ass apdulı̧̧⿻šanos [132]. Priekšējā vitrektomija tiek veikta iedzimtas kataraktas pacientiem līdz divu gadu vecumam. Mugurējā kapsulotomija tiek veikta bērniem līdz septiṇu gadu vecumam. Bērnu oftalmologa un kataraktas ķirurga priekšā ir izvēle, kā koriğēt pēcoperācijas afakiju. To var koriǵēt ar brillēm, kontaktlēcām vai operācijas laikā implantēt acī intraokulāro lēcu (IOL) [55, 71, 111]. Veicot intraokulārās lēcas implantāciju, var izmantot dažādas operācijas tehnikas. Pediatriskie tīklenes ķirurgi, veicot centrālo mugurējo kapsulektomiju, biežāk izvēlas pars plana/plicata ķirurǵisko pieeju. Pediatriskie priekšèjā segmenta ķirurgi vairāk izvēlas un priekšroku dod limbālai/radzenes ķirurǵiskai pieejai [132]. Viens no vadošajiem pasaules pediatriskās kataraktas ķirurgiem un ekspertiem Scott R.Lambert iesaka lēcas aspirāciju, primāru mugurējo kapsulotomiju, priekšējo vitrektomiju ar intraokulāras lēcas implantāciju iedzimtu kataraktu pacientiem veikt tikai pēc sešu mēnešu vecuma [55].

Nejaušinātā multicentru prospektīvā pētījumā - "Zīdaiņu afakijas ārstēšanas pētījumā" (Infant Aphakia Treatment Study, IATS) - tika izvērtēta labākā refraktīvā korekcija bērniem ar iedzimtu unilaterālu kataraktu, secinot, ka nevienai no šìm metodēm nav priekšrocību [49]. Pašreiz ir atzīts, ka IOL implantācija ir droša un ar labiem rezultātiem bērniem, vecākiem par diviem gadiem. Lielā daḷā pasaules valstu pediatriskās kataraktas ķirurgi to rutīnā dara. Divi salīdzinoši nesen publicēti pētījumi ir iesnieguši pierādījumus par IOL implantācijas efektivitāti un drošumu arī jaunākiem bērniem [95, 105]. "Zīdaiņu afakijas ārstēšanas pētîjums" un IOLu2 pêtījums izgaismoja salīdzinoši lielo perioperatīvo un postoperatīvo komplikāciju skaitu zīdaiņiem, kam IOL implantācija veikta līdz sešu mēnešu vecumam [94, 105]. Salīdzinot iegūto redzes asumu 4,5 gadu vecumā vienpusējas kataraktas pacientiem, IATS neparādīja izteiktu 
atšksirību starp bērniem, kam afakija tika koriǵēta ar kontaktlēcām, un bērniem, kuriem bija implantētas intraokulārās lēcas. IATS atrada, ka acīs ar IOL implantācijām biežāk atkārtojās lēcas reproliferācijas, radot redzes ass apduļ̧̧̧ojumus, kā arī bija biežākas atkārtotas operācijas [49]. IOLunder2 pētījums pētīja lielu Apvienotās Karalistes un Īrijas bilaterālas un unilaterālas iedzimtas kataraktas pacientu kohortu, kam kataraktas operācija tika veikta agrāk nekā divu gadu vecumā. Bērniem ar bilaterālu kataraktu, operējot viņus agrīni, gadu pēc operācijas tika atrasta tendence labākiem redzes rezultātiem [105]. Taču, līdzīgi kā zīdaiņu afakijas ārstēšanas pētījumā (IATS), bērniem ar IOL implantācijām tika novērots biežāks reoperāciju skaits [94, 105].

Domājot par konkrētas intraokulāras lēcas izvēli, lielākā daļa ķirurgu kataraktas operācijās izmanto hidrofobiskas akrila lēcas [80], bet iespējami arī citi varianti. Bērniem, kas jaunāki par septiņiem gadiem, radzenes griezieni tiek slēgti, uzliekot 10/0 neuzsūcošas (piem., neilona) šuves. Ja bērna vecums ir virs septiņiem gadiem un/vai viṇš labprāt un viegli sadarbojas, radzenes šuves parasti netiek liktas. Radzenes griezienu vietas tiek stabilizētas, veicot hidratāciju (radzenes stromas slāņos ap griezienu tiek ievadīts BSS šķīdums). Bērnam pēc operācijas tiek uzmanīgi un regulāri veikta redzes un acu izmeklēšana. Ja tiek veikta vienas un tad otras acs kataraktas operācija, laika starpībai jābūt pēc iespējas mazai, lai izvairītos no dziļas ambliopijas otrajai acij. Vienlaicīga bilaterālas kataraktas operācija ir apsverama zīdaiṇiem ar nopietnām blakusslimībām, kas apdraud vispārējās narkozes drošumu. Tomēr vienmēr jābūt apsvērtam bilaterālu endoftalmītu riskam [55].

\subsection{Pēcoperācijas perioda novērošana (follow up) un iespējamās komplikācijas}

\subsubsection{Oklūziju terapija un pēcoperācijas refrakcijas kḷūdas korekcija}

Bērna redzes nobriešanas jutīgais (sensitive) periods ir līdz 7-8 gadu vecumam, šajā laikā redzes sistēmai piemīt zināms elastīgums [26]. Sekundāri kapsulas apdulı̧ķojumi, zīlītes membrānas, šķielēšana, sekundāra glaukoma, refrakcijas maiņa un neatbilstība korekcijai negatīvi ietekmē redzes attīstību [80]. Ja bērna vecums agrīnas ķirurǵiskas korekcijas laikā ir ļoti mazs un bērns sadarbojas nepietiekami, lai pamanītu izmainītu redzes asumu, paaugstinātu acs intraokulāro spiedienu un citas sekundāras pēcoperācijas komplikācijas, ir nepieciešama regulāra un uzmanīga bērna uzvedības un acu stāvokḷa novērošana. [4, 70]. Arī pēc redzes sensitīvā perioda, kad redzes asumam it kā vairs nebūtu jāmainās, ir nepieciešamas atkārtotas redzes pārbaudes un bērnu oftalmologa konsultācijas, kā arī labi apmācīti vecāki, kas mācēs saskatīt bērna redzes un acu atšķirīibas sekundāru vēlīnu komplikāciju gadījumos un refrakcijas izmaiņu gadījumos [25]. 
Bērniem, kas dzimuši ar vienpusēju redzei nozīmīgu kataraktu, vienmēr būs iespējama ambliopijas attīstība [25]. Oklūziju terapijas ietekmējošos faktorus pētījuši daudzi autori, atklājot, ka sliktai oklūziju panesībai no bērnu un vecāku puses ir visstingrākā saistība ar sliktu redzes attīstību, ārstējot vienpusēju kataraktu [13]. Pētot ambliopijas ārstēšanu un sadarbību, veicot oklūzijas, pierādīts, ka ne tikai oklūzija uzlabo redzes asumu neaizklātajā acī, bet arī redzes asums slimajā acī korelē ar iespēju veikt oklūzijas. Jo labāks redzes asums, jo labāk bērns sadarbosies, veicot labāk redzošās acs aizklāšanu [24]. "Zīdaiņu afakijas ārstēšanas pētījumā”" visiem bērniem pirmajos piecos gados pēc vienpusējas kataraktas operācijas tika nozīmēta otras acs oklūzija. Sākot no otrās pēcoperācijas nedēḷas, līdz astoṇu mēnešu vecumam bērna aprūpētājiem tika nozīmēta un izskaidrota oklūzija otrai veselajai acij $1 \mathrm{~h} /$ dienā/mēnes̄̄. Pacientiem, vecākiem par astoņiem mēnešiem, oklūzija tika nozīmēta pusi no nomoda stundām katru dienu, vai pilnas dienas oklūzija katru otro dienu [49]. Pārāk liela okludēšana var izraisīt redzes pasliktināšanos pirms tam labākajā acī un izmainītu binokularitāti. Unilaterālas kataraktas gadījumos binokularitāti izdodas iegūt l̦oti reti, var teikt, tā ir gandrīz neiespējama. Arī binokulāras iedzimtas kataraktas gadījumos binokularitāte bieži ir traucēta [61].

Gan afakijas, gan artefakijas gadījumos bērnam pēc iedzimtas kataraktas ķirurğiskas korekcijas būs nepieciešama optiskā korekcija. Dabiskās lēcas neesamības dēḷ nedarbosies akomodācija, un, lai iegūtu skaidru attēlu uz tīklenes gan tuvumā, gan tālumā, būs nepieciešamas atšksirīgas koriǵējošās optiskās lēcas. Literatūrā optiskā korekcija pēc kataraktas ķirurǵiskas korekcijas vairāk ir analizēta afakiskām acīm, taču tā ir l̦oti nozīmīga arī pseidofakiskām acīm. Afakijas korekcijas standartmetode ir cietās, gaisu caurlaidīgās kontaktlēcas [118]. Kontaktlēcu priekšrocības ir nepārtraukta, salīdzinoši viegla, ērta optiskā korekcija salīdzinoši smago afakisko brilııu vietā. Tā kā zīdainis pats vēl neizprot korekcijas nozīmību, sevišş̧i vienpusējas kataraktas gadījumos, viņš no kaut kā lieka uz galvas pēc iespējas ātrāk cenšas atbrīvoties. Brilles zīdainis noņems, ar kontaktlēcām tas nebūs tik viegli izdarāms. Sevišķi kontaktlēcu priekšrocība parādās anizometropijas korekcijā gan afakiju, gan pseidofakiju gadījumos [118]. Tomēr kontaktlēcu ielikšana un izņemšana no zīdaiņa acs ir apgrūtināta. Nereti bērns, jau ieraugot kontaktkorekcijas kabinetu un saprotot, kas sekos, sāk raudāt un kḷūst histērisks. Tas ir iemesls, kāpēc afakiskas un, jo sevišķi, pseidofakiskas brilles bērnu vecumā starp 18 mēnešiem un četriem gadiem tiek labāk tolerētas. Vienpusēju vai abpusēju mikroftalmu gadījumos brillēm ir arī labs kosmētisks efekts [80]. Pilnai bērna vizuālajai rehabilitācijai neaizstājams ir vecāku atbalsts $[1,47,80]$.

Visos gadījumos pēc iedzimtas un bērnu vecuma kataraktas operācijas ir jārēķinās ar iespējamām komplikācijām. Bērnu vecumā tās noteikti būs daudz biežāk nekā pieaugušo vecumā. 
Biežo komplikāciju iemesls ir daudz izteiktāka pēcoperācijas iekaisuma atbilde zīdaiņa un bērna acī nekā pieauguša pacienta acī. Ja zīdainim vienlaikus ir priekšējā vai mugurējā acs segmenta iedzimtas patologijas, tās veicina pēcoperācijas komplikāciju attīstību. Bērna acs augšana noteiks refrakcijas izmaiņas, kas bieži ir neprognozējamas [126]. Visi minētie iemesli kopā rad̄̄s turpmāk minētās pēcoperācijas komplikācijas.

\subsubsection{Sekundāra glaukoma}

Viena no biežākajām un nopietnākajām problēmām pēc pediatriskās kataraktas ķirurğiskas korekcijas ir sekundāra glaukoma. Chen un kolēǵu pētījumos minētais afakiskas glaukomas attīstības risks pēc iedzimtas kataraktas operācijas ir 37,1\% pacientiem pirmā gada laikā, 75,9\% pacientiem sešu gadu laikā, 100\% - 33 gadu laikā [16, 17].. Agrākajos pētījumos bija dokumentēti secinājumi, ka IOL implantācija bērnu vecuma kataraktas pacientiem samazina pēcoperācijas glaukomas riskus, ka IOL implantācija "aizsargā” no glaukomas attīstības [6, 70]. Jaunākie randomizētie multicentru pētījumi - "Zīinaiṇu afakijas ārstēšanas pētījums” (IATS) ASV un "IoL zem 2" (IoLunder2) pētījums Apvienotajā Karalistē un İrijā - uzskatāmi parāda, ka IOL implantācija nepasargā no sekundāras glaukomas attīstības [63, 105]. "Pierādīta vai aizdomās turēta" glaukoma attīstījās 35\% acu kontaktkorekcijas grupā pret $28 \%$ acu IOL grupā $(\mathrm{P}=.55)$ [63]. Tas pierāda, ka intraokulārais spiediens jāmēra katrā bērna apskates reizē [40, 47, 80]. Glaukomas diagnostiku gan nevar balstīt tikai uz paaugstināta intraokulārā spiediena mērījumiem. Simsek un kolēǵi atspoguḷo, ka radzenes centrālais biezums iedzimtas kataraktas pacientiem bieži ir palielināts [102]. Lai pamatoti diagnosticētu sekundāru glaukomu pēc iedzimtas kataraktas operācijas, jāizvērtē redzes nerva (RN) diska oftalmoskopiskais attēls, atzīmējot RN ekskavācijas lielumu, jāsalīdzina acs aksiālā garuma izmaiņas, jāseko radzenes diametra izmain̄ām. Par sekundāru glaukomu liecina arī strauja refrakcijas miopiskā novirze. Pēdējos gados arī bērnu vecumā ar oftalmoloǵiskās koherentās tomogrāfijas tehnoloǵijām iespējams novērtēt redzes nerva šķiedru slāņu biezumu bērniem un zīdaiņiem. Vecākiem bērniem iespējams novērtēt un salīdzināt redzes lauku izmaiņas [40, 47, 80]. Šobrīd nav zināmu pasākumu, lai samazinātu glaukomas sastopamību šajā riska grupā. Modrība par iespējamu sekundāras glaukomas attīstību pacientiem pēc iedzimtas kataraktas operācijas jāsaglabā visas dzīves laikā [92]. 


\subsubsection{Redzes ass reproliferācija, sekundāra katarakta}

Visbiežākā komplikācija pēc pediatriskās kataraktas operācijas ar IOL implantāciju, kas veikta pirms septiṇu mēnešu vecuma, ir redzes ass reproliferācija [92]. "Zīdaiṇu afakijas ārstēšanas pētîjumā” (IATS) 24 acīs no 57 (42\%), kurās implantēja intraokulāru lēcu, attīstìjās redzes ass reproliferācija salīdzinājumā ar afakiskām acīm, kurās tikai vienam pacientam no 57 attīstìjās šì komplikācija [94, 95]. Plager un kolēgi citos pētìjumos, salīdzinot bērnus, kam kataraktas operācija veikta līdz sešu mēnešu vecumam, un vecākus bērnus, novēro, ka nevienam bērnam, vecākam par astoņiem mēnešiem, redzes ass reproliferācija netiek novērota [92, 96]. Reproliferācija veidojas no fibrīna, kas formē zīlītes membrānu, kā arī no atstātajiem acs lēcas mugurējās kapsulas audiem. Zīdaiņiem agrīnā vecumā joprojām notiek ātra lēcas šūnu proliferācija. Pēc lensektomijas agrīnā vecumā, kaut arī liekas, ka viss redzamais kortikālais lēcas materiāls ir aspirēts, papildus veidojas jaunas lēcas epitēlija šūnu proliferācijas. Visbiežāk šīs reproliferācijas šūnas izvietojas ārpus redzes ass, veidojot Zemmeringa gredzenu. Operācijas laikā starp kapsulām ievietojot intraokulāro mākslīgo lēcu, lēcas proliferatīvās šūnas parasti veidojas uz IOL mugurējās virsmas tuvu redzes asij. Šajos gadījumos, lai atbrīvotu redzes asi, ir nepieciešama sekundāra proliferatīvo šūnu aspirācija [92]. Tieši šì iemesla dēḷ, lai izvairītos no mugurējās kapsulas apdulķ̧ošanās, bērniem līdz divu gadu vecumam kopā ar lensektomiju tiek veikta mugurējā kapsulotomija un priekšējā vitrektomija. Bērniem, vecākiem par diviem gadiem, kā jau iepriekš minēts literatūras apskata 2.7.2. nodạ̦ā, kas apraksta kataraktas ķirurğiskas korekcijas tehniku, priekšējo vitrektomiju neveic. Bērniem, vecākiem par septiņiem gadiem, bet dažreiz arī agrākā vecumā, neveic mugurējo kapsuloreksi jeb mugurējo kapsulotomiju, mugurējo kapsulu atstājot intaktu. Tomēr bērniem, kas jaunāki par četriem gadiem, atstājot lēcas mugurējo kapsulu intaktu, izveidojas nozīmīga mugurējās kapsulas apduḷķošanās, ko dēvē arī par sekundāru kataraktu [80]. Redzes ass reproliferācijas un sekundāras kataraktas gadījumos bērniem, kas nesadarbojas, tiek veikta lēcas masu ķirurğiska evakuācija un mugurējās kapsulas discisija. Vecākiem bērniem, kas sadarbojas, bez anestēzijas tiek veikta YAG lāzera kapsulotomija [126]. Jebkura no šīm manipulācijām vai operācijām var mainīt acs refrakciju, kas nosaka atkārtotas retinoskopijas nepieciešamību [92]. Lai rezultāti būtu ticami, retinoskopija jāveic pilnā cikloplēgeijā. 


\subsection{4. Šksielēšana}

Nākamā iedzimtas kataraktas komplikācija ir šḳielēšana. Šķielēšana kā komplikācija ļoti bieži sastopama unilaterālas kataraktas gadījumos, binokulārās redzes traucējumi bieži ir arī bilaterālas kataraktas gadījumos. Literatūrā tiek minēts, ka šķielēšana un traucēta binokularitāte attīstās no 42\% līdz 78\% iedzimtas kataraktas pacientu [11]. "Zīdaiņu afakijas ārstēšanas pētîjuma" autori ziņo, ka 70\% pētìjumā iekļauto bērnu 12 mēnešu laikā pēc kataraktas operācijas attīstìjās šķielēšana [61]. Bērniem ar iedzimtu kataraktu biežāk sastopama ezotropija, bērniem ar iegūtu kataraktu biežāk sastopama eksotropija [129].

\subsubsection{Citas komplikācijas}

Ļoti nopietna un prognostiski slikta komplikācija pēc kataraktas operācijas bērnu vecumā ir endoftalmīts (pārsvarā bakteriāls), kas gan reti sastopams. Bērniem bieži sastopamā ductus nasolacrimalis obstrukcija, augšejāa respiratorā trakta infekcijas, periorbitālās ādas slimības, ko pārsvarā izraisa Staphylococcus aureus un Streptococcus pneumoniae, paaugstina risku pēcoperācijas endoftalmīta attīstîbai [92]. Pêtījumi, kas atspoguḷo dažāda veida periorbitālas, intrakamerālas un intraokulāras injekcijas, kas samazinātu iespējamo endoftalmītu risku, ir loti kontroversāli. Moksifloksacīns ir kḷuvis par populāru intrakamerālu antibiotiku. Ir pētījumi arī par intraokulārām cefuroksīma injekcijām [92].

Dažiem zīdaiņiem pēc lensektomijas un priekšèjās vitrektomijas attīstās hemorāǵiska retinopātija. Parasti tās ir liesmveidīgas hemorāgijas mugurējā polā, kas uzsūcas, neatstājot sekas. Dažreiz hemorāgijjas var būt fovea rajonā, kas tādā gadījumā izraisa ievērojamu redzes asuma samazinājumu [55]. Tīklenes atslānnošanās pēc kataraktas operācijām bērnu vecumā ir ļoti reti. Tās biežāk sastopamas garīgi atpalikušiem pacientiem, kuri paši sevi pēc operācijām traumējuši [55]. Cistoīda makulas tūska bērniem ir reta [55]. Radzenes tūska pēc kataraktas operācijas parasti pāriet dažās dienās, tā korelē ar operācijas ilgumu. Tā var būt saistîta ar ķimikālijām un šķ̄idumiem, ar ko apstrādāti ķirurǵiskie instrumenti, tāpēc pēc iespējas vienmēr būtu jālieto vienreizlietojamās kanules un instrumenti [55].

\subsubsection{Pēcoperācijas medikamentozāā ārstēšana}

Vilsona un Trivedi grāmatā "Pediatric Cataract Surgery" 11 pediatriskās kataraktas ķirurgi no visas pasaules apraksta savu pediatriskā vecuma kataraktas pacientu pēcoperācijas medikamentozo ārstěšanu [128]. Tikai viens no viniiem uzreiz pēc operācijas priekšejjā kamerā injicēja steroīdus. Divi no viņiem pēc operācijas subkonjunktivāli injicēja sterō̄du un antibiotiku 
šķīdumu. Gandrīz visi ķirurgi pēcoperācijas periodā saviem pacientiem lokāli nozīmēja Prednisolone $1 \%$ vai Dexamethasone pilienus un Tobramycin pilienus, vai kombinētus Dexamethasonum/Tobramycin pilienus. Gandrīz visi ķirurgi pēcoperācijas periodā nozīmēja Atropin $1 \%$ vai Cyclopentolate $0,5 \%$ vai $1 \%$ pilienus. Antibiotikas tika pilinātas vienu vai divas nedēḷas. Sterōidi tika pilināti vismaz sešas nedēḷas, sākuma periodā ik pēc divām stundām, pēc divām nedēḷām sākot lēni samazināt pilienu daudzumu. Jo mazāks bija bērna vecums ķirurğiskas korekcijas laikā, jo intensīvāka pēcoperācijas terapija tika nozīmēta [126].

\subsection{Acs refrakcijas miopiskā novirze \\ 1.9.1. Acs augšana}

Bērna acs ir attīstībā esoša optiska sistēma [37]. Šīs optiskās sistēmas augšanu un attīstību regulē fenomens, ko mēs zinām kā emetropizāciju [54]. Emetropizācijai izšķir pasīvo un aktīvo komponentu [106]. Normālai jaundzimušā bērna acs augšanai raksturīga acs aksiālā garuma (AG) palielināšanās, kas kombinējas ar proporcionālu acs optisko komponentu - acs radzenes un acs lēcas optiskā stipruma - samazināšanos. To sauc par pasīvo emetropizāciju [37]. Tas nosaka, ka, bērnam augot un acs lielumam izteikti palielinoties pirmā dz̄̄vības gada laikā, acs optiskajā sistēmā neveidojas lielas refrakcijas izmaiņas. Aktīvā emetropizācija ir saistīta ar aktīvu redzes atpakaļsaites lomu bērna acs augšanas kontroles procesā [106,136]. Lielākā daļa acs izmaiņu notiek bērna augšanas pirmajos 18 mēnešos. Veseliem zīdaiņiem acs aksiālais garums palielinās no vidēji 16,8 mm piedzimstot līdz 23,6 mm pieaugušā vecumā, radzenes liekums samazinās no vidēji 51,2 D līdz 43,5 D, lēcas optiskais stiprums mainās no 34,4 D līdz 18,8 D. Šo daudzo izmaiņu rezultātā bērna acī veidojas tikai apmēram -0,9 D liela refrakcijas novirze [37].

\subsubsection{Pseidofakiskas un afakiskas acs augšana}

Emetropizācijas process pēc kataraktas operācijas bērnu vecumā ir izmainīts un joprojām grūti izprotams. Trūkstot acs dabiskajai lēcai pēc kataraktas operācijas bērnu vecumā, acs nav spējīga kompensēt refrakcijas izmaiņas ar pasīvās emetropizācijas procesu [77, 78, 79]. Veidojas liela acs refrakcijas kḷūda miopiskā virzienā - miopiska novirze (MN). Miopiskā novirze var sasniegt 10 un vairāk dioptrijas un parasti atbilst logaritmiskai līknei [77, 78]. Arvien vairāk operējot un iegūstot pieredzi bērnu vecumā izmantot intraokulāru afakijas korekciju, parādījās daudz pētījumu un ziņojumu par pseidofakisku acu augšanu, acs aksiālā garuma palielināšanos, refrakcijas izmaiṇām, parādījās miopiskās novirzes un refrakcijas izmaiṇu salīdzinājumi acīm ar afakiju un pseidofakiju [piemēram:5, 28, 57, 85]. Daudzi pētījumi, kas tika veikti ar dz̄ivniekiem, 
aț̣āva arvien labāk saprast acs augšanas un refrakcijas izmaiņas pacientiem ar iedzimtu kataraktu pēc kataraktas ekstrakcijas ar vai bez intraokulāras lēcas implantācijas [48, 60, 101, 124]. VanderVeen pediatriskās kataraktas ķirurğijas ekspertu Lloyd un Lambert 2017. gadā izdotajā grāmatā "Congenital Cataract: A Concise Guide to Diagnosis and Management" pētījumus par miopisko novirzi apkopojusi tabulā (1.4. tab.). Vienkopus te var izsekot miopiskās novirzes (MN) lielumam un diapazonam, komentāros var izlasīt piezīmes par dažādu ietekmējošo faktoru darbību.

Kā miopiskās novirzes galveno iemeslu literatūrā min izjauktu acs augšanas procesu bērnam pēc lensektomijas bez vai ar mākslīgās intraokulārās lēcas implantāciju agrīnā bērna vecumā [77, 78]. Bet tiek uzskaitīti arī citi acs augšanu un miopiskās novirzes attīstību ietekmējošie faktori - bērna vecums kataraktas operācijas laikā, traucētas redzes attīstības ietekme, lateralitāte, kataraktas morfoloǵiskais tips, pēcoperāciju komplikāciju attīstība. Trivedi un Wilson grāmatā "Pediatric Cataract Surgery: Techniques, complications and management" apkopojuši miopiskās novirzes ietekmējošos faktorus, sadalot tos vispārējos, okulāros un funkcionālos [126].

1.4. tabula

Miopiskā novirze pēc iedzimtas kataraktas ķirurğiskas korekcijas pseidofakiskās zīdaiṇu acīs [121]

\begin{tabular}{|c|c|c|c|c|c|}
\hline Pētījums & $\begin{array}{c}\text { Vecums } \\
\text { operācijas laikāa } \\
\text { (vidējais) }\end{array}$ & $\begin{array}{c}\text { Acu } \\
\text { skaits }\end{array}$ & $\begin{array}{c}\text { Vid. } \\
\text { pacienta } \\
\text { novēroš. } \\
\text { ilgums }\end{array}$ & $\begin{array}{c}\text { Miopiskāa } \\
\text { novirze (D) }\end{array}$ & Komentāri \\
\hline $\begin{array}{l}\text { Dahan } \\
\text { and } \\
\text { Drusedau } \\
(1997)\end{array}$ & $\begin{array}{l}<18 \text { mēneši } \\
(9,36 \pm 6,12 \\
\text { mēn.) } \\
\text { Apakškopa no } \\
156 \text { acīm } 99 \\
\text { bērniem līdz } 8 \mathrm{~g} . \\
\text { v. }\end{array}$ & 68 & $\begin{array}{l}6,93 \pm \\
3,42 \text { gadi }\end{array}$ & $-6,39 \pm 3,68 \mathrm{D}$ & $\begin{array}{l}\text { Lielāka miopiskā } \\
\text { novirze jaunākās } \\
\text { vecuma grupās }\end{array}$ \\
\hline $\begin{array}{l}\text { Griener et } \\
\text { al. (1999) }\end{array}$ & 2-4 mēneši & $\begin{array}{l}11 ; \\
\text { visas } \\
\text { vienpus. } \\
\text { kataraktas }\end{array}$ & 5,6 gadi & $\begin{array}{l}-6,12 \mathrm{D} \\
\text { (diapazons: } \\
-3,75 \mathrm{li} \mathrm{dz} \\
-12,75 \mathrm{D})\end{array}$ & \\
\hline $\begin{array}{l}\text { Lambert } \\
\text { et al. } \\
\text { (1999) }\end{array}$ & $\begin{array}{l}<6 \text { mēneši } \\
(10 \pm 6 \text { nedēlas })\end{array}$ & $\begin{array}{l}11 ; \\
\text { visas } \\
\text { vienpus. }\end{array}$ & 1 gads & $\begin{array}{l}-5,49 \mathrm{D} \\
\text { (diapazons: } \\
-2 \text { li dz -14 D) }\end{array}$ & $\begin{array}{l}\text { Diviem pacientiem an } \\
\text { glaukomu bija } \\
\text { vislielākā miopiskā } \\
\text { novirze }\end{array}$ \\
\hline
\end{tabular}


1.4. tabulas turpinājums

\begin{tabular}{|c|c|c|c|c|c|}
\hline Pētījums & $\begin{array}{c}\text { Vecums } \\
\text { operācijas laikā } \\
\text { (vidējais) }\end{array}$ & $\begin{array}{l}\text { Acu } \\
\text { skaits }\end{array}$ & $\begin{array}{c}\text { Vid. } \\
\text { pacienta } \\
\text { novēroš. } \\
\text { ilgums }\end{array}$ & $\begin{array}{c}\text { Miopiskāā } \\
\text { novirze (D) }\end{array}$ & Komentāri \\
\hline $\begin{array}{l}\text { McClatche } \\
\text { y et al. } \\
(2000)\end{array}$ & $\begin{array}{l}<6 \text { mēneši } \\
(0,30 \text { gadi) } \\
6-12 \text { mēneši } \\
(0,60 \text { gadi) } \\
\text { Apakškopā no } \\
100 \\
\text { pseidofakiskām } \\
\text { acīm } 83 \\
\text { pacientiem līdz } \\
10 \text { g. v. }\end{array}$ & $\begin{array}{l}22 ; \\
14 \text { vienpus. } \\
22 ; \\
12 \text { vienpus. }\end{array}$ & $\begin{array}{l}8 \text { gadi } \\
7,76 \text { gadi }\end{array}$ & $\begin{array}{l}-6,68 \mathrm{D} \\
-7,82 \mathrm{D}\end{array}$ & $\begin{array}{l}\text { Miopiskā novirze } \\
\text { lielāka vienpus. } \\
\text { gadījumos } \\
\text { < } 6 \text { mēneši un ar } \\
\text { zemāku gala redzes } \\
\text { asumu. } \\
\text { Vecākiem par } 6 \\
\text { mēnešiem vienpus. } \\
\text { gadījumos miopiskā } \\
\text { novirze ir mazāka } \\
\text { nekā bilaterālos } \\
\text { gadījumos }\end{array}$ \\
\hline $\begin{array}{l}\text { O'Keefe et } \\
\text { al. (2001) }\end{array}$ & $\begin{array}{l}<12 \text { mēneši } \\
(4 \text { mēneši) }\end{array}$ & $\begin{array}{l}27 ; \\
13 \text { vienpus. }\end{array}$ & 3,42 gadi & $-6,0 \mathrm{D}$ & $\begin{array}{l}\text { Lielākā novirze } \\
\text { parādās pirmajos } 24 \\
\text { mēnešos }\end{array}$ \\
\hline $\begin{array}{l}\text { Crouch et } \\
\text { al. (2002) }\end{array}$ & \begin{tabular}{|l|}
$1-2$ gadi \\
Apakškopa no \\
52 acīm 42 \\
pacientiem līdz \\
18 g. v. \\
\end{tabular} & 10 & 6,35 gadi & $\begin{array}{l}-5,96 \mathrm{D} \\
\text { (diapazons } \\
-3,06 \text { līdz } \\
-8,87 \text { ) }\end{array}$ & $\begin{array}{l}\text { Lielākais augšanas } \\
\text { apjoms starp } 1 \text { un } 3 \\
\text { gadu vec. ar daudz } \\
\text { lineārāku augšanas } \\
\text { tendenci vēlāk }\end{array}$ \\
\hline $\begin{array}{l}\text { Fan et al. } \\
(2006)\end{array}$ & $\begin{array}{l}<1 \text { gads } \\
(6,7 \pm 3,9 \\
\text { mēneši })\end{array}$ & $\begin{array}{l}34 ; \\
6 \text { vienpus. }\end{array}$ & 3 gadi & $\begin{array}{l}-7,11 \pm 3,17 \mathrm{D} \\
\text { (diapazons } \\
-4,7 \mathrm{li} \mathrm{dz} \\
-10,69 \mathrm{D})\end{array}$ & $\begin{array}{l}\text { Lielākās izmaiñas } \\
6 \text { mēnešus pēc } \\
\text { operācijas }\end{array}$ \\
\hline $\begin{array}{l}\text { Gouws } \\
\text { et al. } \\
(2006)\end{array}$ & $\begin{array}{l}<1 \text { gads } \\
(15 \text { nedēlas })\end{array}$ & $\begin{array}{l}28 ; \\
8 \text { vienpus. }\end{array}$ & 7,92 gadi & $\begin{array}{l}36 \text { mēneši pēc } \\
\text { operācijas: } \\
-3,44 \text { D } \\
\text { (diapazons } \\
+2,0 \text { līdz } \\
-15,0 \text { D) }\end{array}$ & $\begin{array}{l}\text { Lielāka vidējā } \\
\text { novirze vienpus. } \\
\text { gadījumiem }(-5,53 \\
\text { vs. }-2,77 \text { D) }\end{array}$ \\
\hline $\begin{array}{l}\text { Ashworth } \\
\text { et al. } \\
\text { (2007) }\end{array}$ & $\begin{array}{l}<1 \text { gads } \\
(18,9 \pm 16,2 \\
\text { nedēḷas })\end{array}$ & $\begin{array}{l}33 ; \\
17 \text { vienpus. }\end{array}$ & $\begin{array}{l}3,7 \pm 2,55 \\
\text { gadi }\end{array}$ & $\begin{array}{l}1 \text { gadu pēc } \\
\text { operācijas: } \\
-5,43 \pm 3,7 \mathrm{D}\end{array}$ & $\begin{array}{l}\text { Lielāka novirze } 1 . \\
\text { gadā pēc operācijas } \\
\text { un tiem, kas operēti } \\
<10 \text { nedēlu vecumāa } \\
(-6,26 \pm 2,91)\end{array}$ \\
\hline $\begin{array}{l}\text { Astle } \\
\text { et al. } \\
(2007)\end{array}$ & $<25$ mēneši & $\begin{array}{l}34 ; \\
18 \text { vienpus. }\end{array}$ & 2,94 gadi & $\begin{array}{l}-5,43 \mathrm{D} \\
\text { (diapazons } \\
-11,88 \mathrm{li} \mathrm{dz} \\
+5,0) \\
\end{array}$ & $\begin{array}{l}\text { Apakšgrupā } \\
\text { zīdaiņiem līdz } 12 \\
\text { mēnešiem līdzīgs } \\
\text { mērījums: }-5,33\end{array}$ \\
\hline $\begin{array}{l}\text { Hoevenaars } \\
\text { et al. (2011) }\end{array}$ & $\begin{array}{l}<1 \text { gads } \\
\text { Apakškopa no } \\
70 \text { acīm } 46 \\
\text { pacientiem līdz } \\
18 \text { g. v. }\end{array}$ & $\begin{array}{l}10 ; \\
6 \text { vienpus. }\end{array}$ & 3 gadi & $\begin{array}{l}-5,26 \\
\text { (diapazons } \\
0 \text { līdz } \\
-8,13 \mathrm{D})\end{array}$ & $\begin{array}{l}\text { Lielāka novirze } \\
\text { vienpus. gadījumos }\end{array}$ \\
\hline
\end{tabular}

Adaptēts no Lloyd un Lambert "Congenital Cataract: A Concise Guide to Diagnosis and Management" 2017 [121]. Piezīme: g. v. - gadu vecumā; vienpus. - vienpusējs. 


\subsubsection{Faktori, kas var ietekmēt afakiskas un pseidofakiskas acs augšanu. Bērna vecums kataraktas operācijas laikā}

Miopiskās novirzes galvenais ietekmējošais faktors ir bērna vecums kataraktas operācijas laikā. Lai to izprastu, tiek apskatīti normālas bērna acs augšanas periodi, kas literatūrā pierādīti un labi dokumentēti [65]. Pirmajā ātrajā augšanas fāzē bērna pirmā gada laikā acs aksiālais garums (AAG) pieaug par 3,7 - 3,8 mm. Otrais periods iezīmēts no otrā līdz piektajam dzīves gadam, kad AAG pieaug par 1,1 - 1,2 mm. Trešajā juvenilajā augšanas fāzē no piecu līdz 13 gadu vecumam AAG pagarinās par 1,3 - 1,4 mm. Pirmā gada ātrā augšanas fāze ir labi dokumentēta, atklājot tās stabilizācijas laika lielu dažādību [65, 37].

Acīm ar iedzimtu kataraktu notiek līdzīgas acs garuma izmaiņas gan pirms, gan pēc kataraktas ekstrakcijas . Vidējais aksiālais garums acīm ar iedzimtu kataraktu ir atšksirīgs (20,6 \pm 2,9 mm) [112] no garuma, kāds ir acīm bez kataraktas Gordona datos (21,9 $\pm 1,6$ mm) [37]. Taču acu augšanai piemīt liela dažādība, kompensējoši mehānismi liek īsākām acīm augt vairāk un garākām - mazāk [115]. Pētījumi ar dzīvniekiem parādījuši, ka, padarot cāļu acis funkcionāli miopiskas ar pozitīvām briḷı lēcām vai funkcionāli hipermetropas ar negatīvām briḷı lēcām, kompensējoši mainās acs augšana [124]. Ja miopija tiek kompensēta, acs augšana apstājas. Ja tiek kompensēta hipermetropija, acs augšana turpinās [116].

\subsection{Redzes prognoze bērniem ar iedzimtu kataraktu}

Redzes prognoze bērniem ar iedzimtu kataraktu pēdējo gadu laikā ir ļoti uzlabojusies. Uzlabojoties kataraktas operācijas tehnoloǵijām un ķirurǵiskajām metodēm, absolūti lielākā daļa kataraktas ekstrakcijas operāciju zīdaiņiem ir veiksmīgas [43]. Bilaterālas nepilnas kataraktas gadījumā redzes attīstības rezultāts vairāk korelē ar apduļ̧̧̣ojuma blīvumu, nevis lielumu. Kodolu kataraktai, lai gan tā ir mazāka nekā lamelāra katarakta, ir sliktāka redzes prognoze [1]. Daudziem bērniem ar bilaterālu agra vecuma kataraktu un tūlītēju ārstēšanu redzes prognoze ir l̦oti laba [71]. Agra vecuma unilaterālai kataraktai ir vissliktākā redzes prognoze, tā ir ļoti atkarīga no agrīnas operatīvas terapijas, intensīvas oklūziju terapijas un refrakcijas korekcijas [71]. Zīdaiņu afakijas pētījuma (IATS) secinājumos atzīmēts, ka sliktāka redzes prognoze ir saistīta ar augstāku refrakcijas augšanas ātrumu afakijas, ne pseidofakijas gadījumos [58]. IC Loyd un S. Lambert grāmatā "Congenital Cataract: A Concise Guide to Diagnosis and Management" EE.Hartmann nodą̧a "Redzes prognozes ietekmējošie faktori” (Baseline Predictors of Visual Outcome) [43]. Izmantojot datus, kas iegūti zīdaiņu afakijas pētījumā 
(IATS), tika definētas trīs pamata raksturojošās kategorijas, kas parasti ir pieejamas jebkuram ārstam [44]:

1) kataraktas acs raksturojošie lielumi;

2) pacienta fiziologiskie raksturlielumi;

3) pacienta gimenes socioloǵiskais raksturojums.

Izslēdzot vairākus lielumus, kas tiešā veidā var ietekmēt redzes attīstības rezultātu, kā, piemēram, sekundāra glaukoma, asociētas acs un zīdaiņa iedzimtas patologijas, tika atrasts, ka tikai bērna vecums primāras ķirurǵiskas korekcijas laikā un veselības apdrošināšanas veids ir statistiski ticama asociācija ar bērna logMAR redzes asumu 4,5 gadu vecumā iedzimtas operētas kataraktas acī [43]. Tomēr nodaļas autors atzīmē, ka ir vairāki citi ietekmējoši faktori, kas ietekmē fināla redzes iznākumu. Tomēr ārstējošam ārstam ASV būtu ieteicams ievērot, ka pacienta gimenēm, kurām ir cits veselības apdrošināšanas veids nekā privāta veselības apdrošināšana, būtu ieteicami saņemt papildu palīdzību, lai viņu bērnam ar iedzimtu redzei nozīmīgu kataraktu nodrošinātu optimālu redzes iznākumu. Palīdzību varētu nodrošināt sociālais darbinieks, kas palīdzētu bērnam un ǵimenei ievērot ieteikto korekciju un noteikto ambliopijas ārstēšanas oklūziju terapiju [44]. 


\section{MATERIĀLS UN METODES}

\subsection{Pētījuma paraugkopa}

Mūsu izlasē ietilpa 85 iedzimtas kataraktas pacienti vecumā no 0 līdz 18 gadiem ar 138 acīm ar pseidofakiju. Visiem pacientiem viens no trim acu mikroķirurgiem (GL, LR, JV) bija veicis lensektomijas un IOL implantācijas operāciju Paula Stradiṇa klīniskajā universitātes slimnīcā Rīgā, Latvijā no 2006. gada 1. janvāra līdz 2016. gada 31. decembrim. Visi pacienti pirms un pēc operācijas tika izmeklēti un novēroti Bērnu klīniskajā universitātes slimnīcā Rīgā, to veica viens oftalmologs (pētījuma autore S.V.). Darbā ar pacientiem bija iesaistîta BKUS optometristu un redzes pedagogu komanda. Visiem pacientiem operācija tika veikta pēc noteiktām indikācijām, pēc vadlīnijām nosakot redzei nozīmīga apjoma un blīvuma kataraktu. Ja katarakta tika apstiprināta kā redzei nozīmīga, kataraktas operācija tika veikta pēc iespējas drīz. Pētījumā netika iekļauti pacienti, kam reizē ar iedzimtu kataraktu tika diagnosticētas citas nozīmīgas okulāras un sistēmiskas slimības. Pirms kataraktas ķirurğiskas korekcijas tika veikta padziḷināta pacienta izmeklēšana un notika informatīva saruna ar bērna vecākiem vai aprūpētājiem. Bērnu klīniskās universitātes slimnīcas Ētikas pārraudzības padome (Ētikas komisija) ir apstiprinājusi šo pētījumu (skat. 1. pielikumu). Visi pacientu vecāki vai aprūpētāji ir informēti par bērna slimību, ārstēšanu, iespējamām komplikācijām, kā arī par dalību pētījumā un pacientu datu ievadi pētījuma datu bāzē (skat. 2. pielikumu). Pacientu vecāki vai aprūpētāji ir parakstījuši aţ̦auju ķirurǵiskai ārstēšanai un pacienta datu ievadīšanai pētījuma datu bāzē. Pētîjuma grupā ietilpa visi noteiktajā laikā Latvijā ārstētie redzei nozīmīgie iedzimtas kataraktas gadījumi.

\subsubsection{Pētījuma izlases raksturojums}

Pētījumā tika iekḷauti 85 pacienti ar iedzimtu kataraktu, tika analizētas 138 acis ar iedzimtu redzei nozīmīgu operētu kataraktu. Pacienti tika operēti laikā no 2006. gada 1. janvāra līdz 2016. gada 31. decembrim. 2.1. tabulā apkopots pētījumā ietverto acu, pacientu, iedzimtas kataraktas ārstēšanas taktikas un biežāko komplikāciju raksturojums. 
Pētījumā iekḷauto iedzimtu kataraktu acu, pacientu un ārstēšanas procesu iedalījumi

\begin{tabular}{|c|c|c|c|c|c|c|}
\hline $\begin{array}{c}\text { Pētījuma } \\
\text { kopa }\end{array}$ & \multicolumn{2}{|c|}{ Iedzimtas katarakasu klasifikācijas } & $\begin{array}{c}\text { IK } \\
\text { ārstēšanas } \\
\text { taktika }\end{array}$ & \multicolumn{2}{|c|}{ IK komplikācijas } \\
\hline $\begin{array}{c}\text { Acis/ } \\
\text { pacientu } \\
\text { skaits }\end{array}$ & $\begin{array}{c}\text { IK sākšanās } \\
\text { laika } \\
\text { klasifikācija } \\
\text { (acis) }\end{array}$ & $\begin{array}{c}\text { IK } \\
\text { morfologiskāa } \\
\text { klasifikācija } \\
\text { (acis) }\end{array}$ & $\begin{array}{c}\text { IK } \\
\text { lateralitāte } \\
\text { (acis) }\end{array}$ & $\begin{array}{c}\text { Emetropa/ } \\
\text { hipermetropa } \\
\text { mērka } \\
\text { refrakcija } \\
\text { (acis) }\end{array}$ & $\begin{array}{c}\text { Bez/ar } \\
\text { sekundāru } \\
\text { glaukomu } \\
\text { (acis) }\end{array}$ & $\begin{array}{c}\text { Bez/ar } \\
\text { sekundāru } \\
\text { kataraktu } \\
\text { (acis) }\end{array}$ \\
\hline $138 / 85$ & $\begin{array}{c}23 \text { totālas } \\
\text { kongenitālas } \\
30 \text { infantilas } \\
42 \text { juvenilas }\end{array}$ & $\begin{array}{c}27 \text { lamelāras } \\
57 \text { nukleāras } \\
22 \text { mugurējas } \\
\text { polāras } \\
9 \text { kortikālas }\end{array}$ & $\begin{array}{c}\text { vienpusējas } \\
108 \\
\text { divpusējas }\end{array}$ & $92 / 46$ & $130 / 8$ & $78 / 60$ \\
\hline
\end{tabular}

Lai raksturotu, iedzimtas kataraktas heterogenitāti, acis pētījumā tika iedalītas pēc iedzimtas kataraktas dažādiem raksturojošiem lielumiem - kataraktas sākšanās laika, morfologiijas un lateralitātes. Pēc kataraktas sākšanās laika pētījumā tika analizētas 66 (47,83\%) acis ar kongenitālu kataraktu, 30 (21,74\%) acis ar infantilu kataraktu un 42 (30,43\%) acis ar juvenilu kataraktu. Kataraktas sākšanās laiks tika noteikts, pamatojoties uz anamnēzi, slimības vēsturi un dokumentāciju pacienta medicīnas kartē. Pēc kataraktas sākšanās laika kataraktas tika iedalītas: iedzimtās kongenitālās, iedzimtās infantilās un iedzimtās juvenilās kataraktās (skat. promocijas darba literatūras apskata 1.5.1. nodaḷu).

Atbilstoši morfologiskai klasifikācijai pētījumā analizēja $23(16,67 \%)$ totālas/difūzas iedzimtas kataraktas, 27 (19,57\%) lamelāras IK, 57 (41,30\%) nukleāras IK, 22 (15,94\%) mugurējās polārās IK un 9 (6,52\%) kortikālās iedzimtas kataraktas. Kataraktas morfologiju bērniem līdz trīs gadu vecumam un nesadarbīgiem bērniem noteica ar rokas biomikroskopu un operācijas mikroskopu vispārējā anestēzijā. Izmeklēšanas laikā tika veikta arī kataraktas fotodokumentācija. Iegūtie fotoattēli tika analizēti gan klīniskām, gan pētījuma vajadzībām. Bērniem, kam kataraktas diagnostikas laikā bija vairāk nekā trīs gadi un kas labi sadarbojās ar ārstējošo ārstu un pētnieku, tika veikta rutīnas biomikroskopija un, ja iespējams, fotodokumentācija. Fotodokumentācijā vairākos palielinājumos un griezumos pēc iespējas tika fotodokumentēts acs priekšējais segments un acs lēca (skat. literatūras apskata 1.5.2. nodaḷu). 
Iedzimtas kataraktas lateralitāti noteica pēc kataraktas esamības vienā vai abās pacienta acīs. Vienpusēja katarakta bija 30 (21,74\%) acīm, 108 (78,26\%) acīm - divpusēja vai bilaterāla katarakta. No bilaterālās kataraktas gadījumiem 75 (54,35\%) bija divpusējās simetriskās un 33 $(23,91 \%)$ divpusējās asimetriskās kataraktas, kas tika apvienotas vienā grupā.

Pēc kataraktas sākšanās laika, morfoloǵiskā tipa un lateralitātes noteikšanas tika pieņemts lēmums par kataraktas ārstēšanas veidu, laiku un intraokulārās lēcas mērķa refrakciju.

Iedzimta katarakta pētījumā tika ārstēta ar divām dažādām intraokulāro lēcu ārstēšanas taktikām - ar emetropas un hipermetropas mērķa refrakcijas IOL implantāciju (sk. literatūras apskata 2.6.4. nodaḷu). Pētījumā tika analizētas 92 (66,66\%) emetropas mērķa refrakcijas acis ar pseidofakiju un 46 (33,33\%) hipermetropas mērķa refrakcijas acis ar pseidofakiju. Tā kā dažādas ārstēšanas taktikas pēc vadlīnijām tika lietotas tikai agrīnā laikā operētiem kataraktas gadījumiem, sīkāk analizējot kongenitālo un infantilo grupu, tika analizētas 51,6\% emetropas kongenitālas acis, 48,4\% hipermetropas kongenitālas acis, 46,7\% emetropas infantilas acis, 53,4\% hipermetropas acis (skat. 2.4.1. nodaḷā 2.4. attēlu).

Pēc kataraktas operācijas kā sekas ārstēšanai var veidoties divas biežākās komplikācijas, ko ietvērām iedzimtas kataraktas ārstēšanas procesa raksturojumā un kas var ietekmēt acs refrakcijas izmaiņas un redzes attīstību, - sekundāra glaukoma un sekundāra katarakta. To diagnostikas veidi un teorētiskais apraksts lasāms promocijas darba literatūras apraksta 1.6.5. nodal̦āa, 1.8.2. nodạ̦ā un 1.8.3. nodal̦ā. 2.1. tabulā iedzimtas kataraktas ārstēšanas procesa raksturošanai attēlotas astoņas (15,2\%) acis ar pseidofakiju un sekundāru glaukomu, 129 (84,4\%) acis ar pseidofakiju bez SG, 58 (42,65\%) acis ar pseidofakiju un sekundāru kataraktu un 80 $(57,35 \%)$ acis ar pseidofakiju bez SK.

Lai analizētu bērna vecumu, kad tika veikta redzei nozīmīgas iedzimtas kataraktas ķirurǵiska korekcija, pētījumā ietvertās IK acis tika iedalītas sešās un četrās grupās. Tā kā lielākās izmaiņas acs augšanā notiek dažos pirmajos mēnešos, operētās acis tika iedalītas nelineāri. Izveidojās sešas IK operācijas bērnu vecuma grupas: no viena līdz sešiem mēnešiem, no septiņiem līdz 12 mēnešiem, no 13 līdz 24 mēnešiem, no 25 līdz 48 mēnešiem, no 49 līdz 84 mēnešiem, no 85 mēnešiem līdz 18 gadiem (2.2 tab.).

Teorētiskais pamatojums iedzimtas kataraktas ķirurǵiskas korekcijas bērnu vecuma grupu un bērna acs augšanas periodu iedalījumiem aprakstīts literatūras apskata 1.9.1. un 1.9.2. nodaḷās. 


\section{Pētījumā iekḷauto pacientu vecums ķirurğiskas korekcijas un intraokulāras lēcas implantācijas laikā}

\begin{tabular}{|l|c|c|c|c|c|c|}
\hline $\begin{array}{l}\text { Bērna vecums primāras kirurğiskas } \\
\text { korekcijas un IOL implantācijas laikā } \\
\text { (mēneši) }\end{array}$ & $1-6$ & $7-12$ & $13-24$ & $25-48$ & $49-84$ & $85-216$ \\
\hline Acis / pac. skaits & $19 / 12$ & $10 / 6$ & $12 / 7$ & $27 / 20$ & $27 / 17$ & $42 / 23$ \\
\hline
\end{tabular}

\subsection{Izlases novērošanas ilgums}

Visi pacienti, kas ietilpa mūsu izlasē, tika novēroti, un viņu dati tika ievadīti datu analīzes sistēmā. Minimālais apsekošanas/novērošanas ilgums bija 6 mēneši, maksimālais - 120 mēneši, vidējais novērošanas ilgums bija 47,8 ( $\mathrm{SD}=37,21)$ mēneši jeb 3,9 gadi. Pacientu novērošanas ilguma iedalījums attēlots 3.1. attēla histogrammā. Novērošanas ilguma izvēlē ņēmām piemēru no citu pētnieku pieredzes, ko VanderVeen apkopojusi tabulā (skat. literatūras apskata 1.9.3. nodaļu).

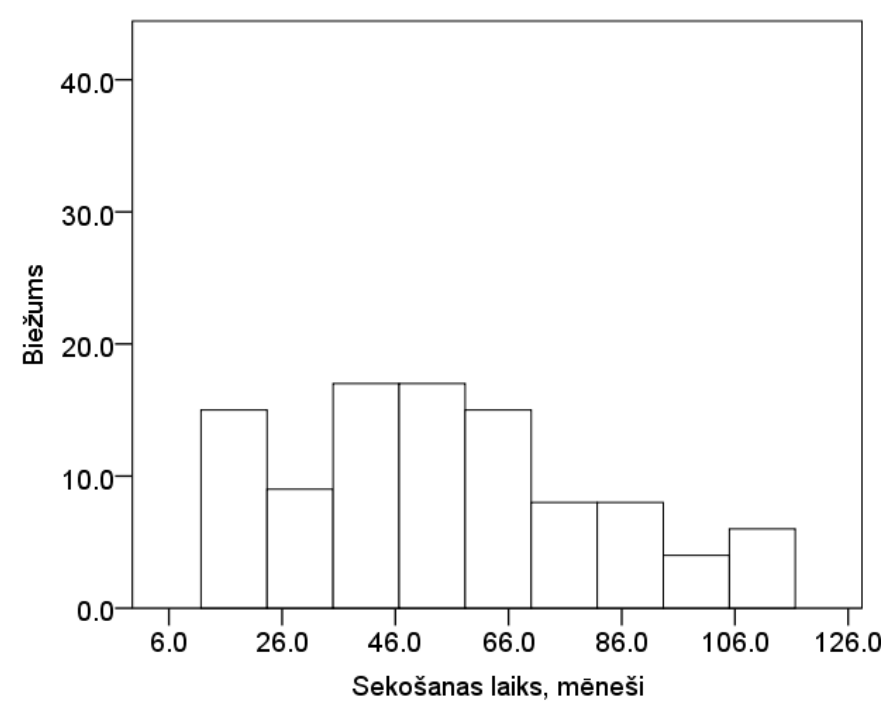

\section{1. att. Pētījumā ietverto pacientu novērošanas ilguma histogramma}

Pētījumā tika iekḷautas visi redzei nozīmīgas desmit gadu laikā Latvijā operētas iedzimtas kataraktas gadījumi. Lai analizētu pietiekamu daudzumu acu un kataraktas pacientu ar iedzimtu kataraktu, kas ārstēti Latvijā, pētījums turpinājās desmit gadus. Novērošanas ilgums ir būtisks acs augšanā, refrakcijas izmaiṇu atspoguļojumā, komplikāciju pievienošanās varbūtībā. Iedzimta katarakta kā viens no reto slimību piemēriem nosaka pētījuma ilgumu un dažādos novērošanas laikus pacientiem. 


\subsection{Acs aksiālā garuma mērījumi un intraokulārās lēcas individuālā stipruma aprēķini, acs augšanas periodi}

Visiem pacientiem pirms kataraktas ekstrakcijas un intraokulāras mākslīgās lēcas implantācijas tika mērīts acs aksiālais garums ar ultrasonogrāfijas A scan kontakta metodi. Parasti tika fiksēti 10 automātiski acs priekšēji mugurējās ass garuma mērījumi un no tiem aprēķināts vidējais acs aksiālā garuma izmērs. Bērniem līdz trīs gadu vecumam un bērniem, kas nesadarbojas, mērījumi tika veikti vispārējā anestēzijā. Intraokulāro lēcu stipruma aprēķināšanai tika izmantotas SRKT un Holliday IOL aprēķināšanas formulas. Vecākiem bērniem IOL aprēķini un acs aksiālā garuma mērījumi tika veikti ar IOL Master programmu. Ja lēcas apdulķ̧ojums ir ļoti izteikts un IOL Master programma ši iemesla dēḷ nespēj veikt aprēķinus, IOL individuālā stipruma aprēķināšana notiek līdzīgi kā zīdaiņa vecuma bērniem. Acs radzenes izliekuma mērīšanai tika lietots rokas vai statīva keratometrs. Ja lēcas izteiktā apduļ̧̧̣ojuma un/vai radzenes apduļ̧̧̣⿻juma dēḷ nevar veikt keratometriju slimajai acij, IOL individuālais stiprums tiek aprēķināts, balstoties uz pacienta otras - veselās - acs keratometrijas un acs aksiālā garuma mērījumiem un otras acs refrakcijas datiem (skat. 1.6.4. un 1.6.6. nodaļu).

Acs augšanas periodi un acs aksiālā garuma izmaiṇas tajos. Pētījuma izlasē iekḷauto pacientu acu iedalījums pēc izdarītās primārās ķirurğiskās korekcijas dažādos acs augšanas periodos.

Acs ābola augšanu var iedalīt trīs periodos [37, 65]. Ātrajā postnatālajā augšanas fāzē pirmajos 18 mēnešos pēc bērna dzimšanas - acs aksiālais garums pieaug par 4,3 mm (vidēji no 16 mm līdz 20,3 mm), infantilajā augšanas fāzē no divu līdz piecu gadu vecumam acs aksiālā garuma pieaugums vidēji ir 1,1 mm, lēnajā juvenilajā fâzē no piecu līdz 13 gadu vecumam acs aksiālā garuma pieaugums ir 1,3 mm (2.2. att.). 


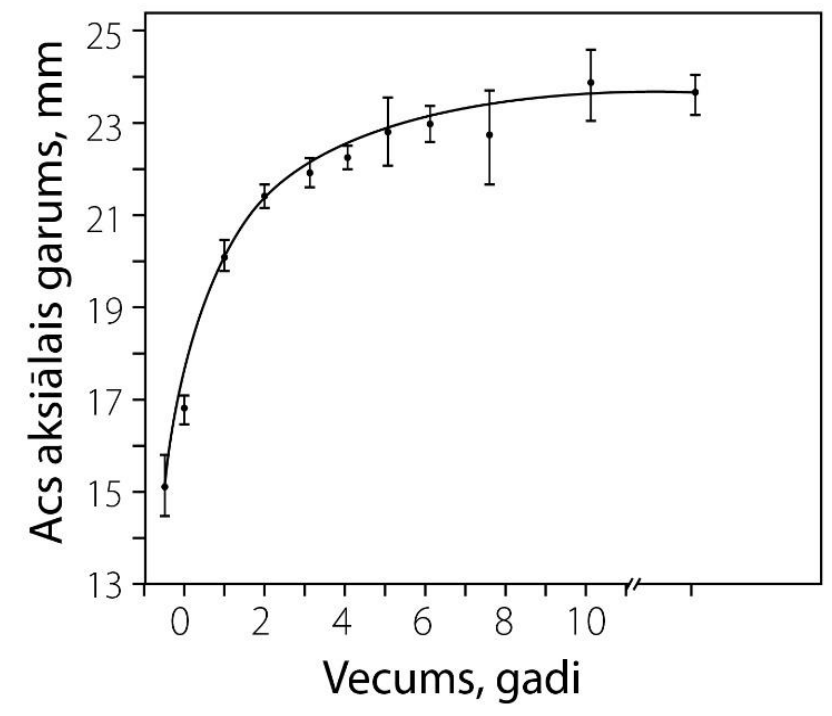

2.2. att. Acs aksiālā garuma pieaugums, bērnam augot

Tā kā acs ābola garums tiešā veidā ietekmē acs refrakciju, salīdzinot acs refrakcijas izmaiņas pēc kataraktas ķirurğiskas korekcijas un IOL implantācijas, ņēmām vērā acs augšanas dažādos periodus un bērna vecumu tajos. Iedalot pētījumā iekḷauto pacientu acis pēc primārās IK ķirurğiskās korekcijas dažādos acs augšanas periodos, ieguvām četras grupas, kurās acu skaits būtiski neatškīīās $(p=0,13)$, skat. 2.3. attēlu.

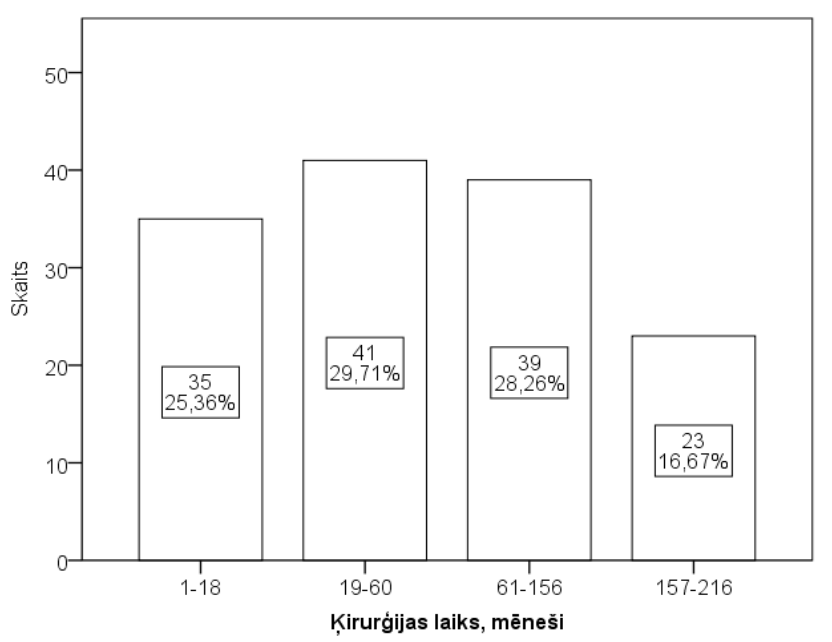

2.3. att. Pētījumā iekḷauto pacientu acu skaits dažādos acs augšanas periodos 


\subsection{Intraokulārās lēcas mērḳa stiprums un divas intraokulārās lēcas implantācijas taktikas}

Balstoties uz divām atšksirīgām intraokulāro lēcu implantācijas taktikām - divām dažādām implantējamo intraokulāro lēcu mērķa refrakcijām - pētījumu sākot, pētījuma izlasē izveidojās viena retrospektīva apakškopa - iedzimta katarakta ar emetropu mērķa refrakciju, pacienti operēti no 2006. līdz 2010. gadam, un viena prospektīva apakškopa - iedzimta katarakta ar hipermetropu mērķa refrakciju, pacienti operēti no 2010. gada līdz 2016. gadam. Vienlaikus iedalot visus pètījuma pacientus grupās pēc kataraktas sākšanās laika, pētījuma izlasē izveidojās 19 emetropas kongenitālas IOL mērķa refrakcijas (MR) acis, 29 hipermetropas kongenitālas IOL MR acis, 17 emetropas infantilas IOL mērķa refrakcijas acis un 18 hipermetropas infantilas IOL MR acis. Visas (42) juvenilas iedzimtas kataraktas acis bija ar emetropu mērķa refrakciju. Lai aprēķinātu vēlamo implantējamo intraokulārās lēcas (IOL) stiprumu, tika izmantotas SRK/T un Holliday 1 IOL aprēķināšanas formulas (skat.1.6.4. nodaḷu).

Visiem pacientiem, kam tika izmantota hipermetropas mērķa refrakcijas implantācijas taktika, implantējām Wilsona un Trivedi pediatriskās kataraktas ķirurğijas grāmatā ieteiktās bērna vecumam operācijas laikā atbilstošās mērķa refrakcijas IOL [131], kas atspoguḷotas 2.3. tabulā.

\section{Intraokulārās lēcas mērḳa stiprums intraokulārās lēcas implantācijai} dažādos bērna vecumos

\begin{tabular}{|l|c|c|c|c|c|}
\hline $\begin{array}{l}\text { Vecums kataraktas ekstrakcijas un } \\
\text { IOL implantācijas laikā }\end{array}$ & $<12$ mēn. & $1-2$ gadi & $3-4$ gadi & $5-6$ gadi & $7-8$ gadi \\
\hline IOL mērķa refrakcija & $+10-+7 \mathrm{D}$ & $+6 \mathrm{D}$ & $+4 \mathrm{D}$ & $+3 \mathrm{D}$ & $+1,5 \mathrm{D}$ \\
\hline
\end{tabular}

\subsubsection{Pētījumā iekḷauto pacientu acu iedalījums pēc divām ārstēšanas taktikām}

Analizējot IOL implantācijas divas taktikas - emetropo un hipermetropo intraokulāro mērķa refrakciju - saistībā ar kataraktas sākšanās laika grupām, kongenitālajā un infantilajā grupā izveidojās divas līdzīgas grupas, kuras pēc implantēto lēcu skaita savā starpā praktiski neatš̌kīās. Juvenilo grupu mēs varam no šì salīdzinājuma izslēgt, jo tajā visām acīm mērḳa refrakcija bija emetropa ( 2.4. att.). 


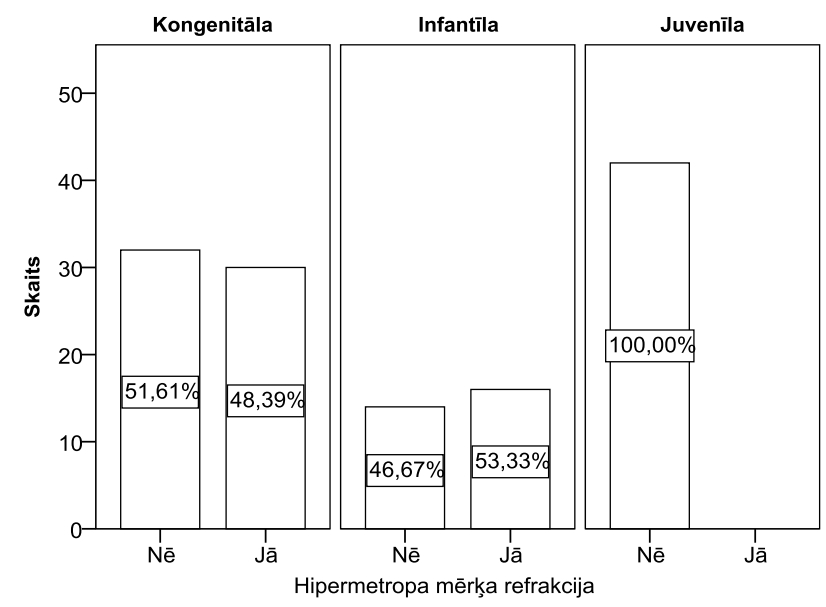

2.4. att. IOL implantācijas emetropās un hipermetropās mērķa refrakcijas taktiku iedalījums kongenitālajā un infantilajā iedzimtas kataraktas sākšanās laika grupās

\subsubsection{Iedzimtas kataraktas acu ar pseidofakiju implantēto intraokulāro lēcu individuālais stiprums}

Katrai iedzimtas kataraktas acij tiek aprēķināts individuāls IOL stiprums. Mūsu izlasē individuālie IOL stiprumi bija no 10 D līdz 36 D. Kongenitālajā grupā minimālais implantētās IOL stiprums bija 11 dioptrijas (D), maksimālais - 40 D, vidēji tas veidoja 28,03 D. Infantilajā grupā vidēji implantētās intraokulārās lēcas stiprums bija 25,12 D, juvenilajā grupā - 24,45 D.

\subsubsection{Acs refrakcijas kḷūdas noteikšana}

Visām acīm vienu nedēlu pēc primārās ķirurǵiskās korekcijas tika mērīta acs refrakcijas kḷūda. Acīm, kas operētas līdz bērna trīs gadu vecumam, acs refrakcijas kḷūda tika mērīta katrus trīs mēnešus, pēc divu gadu vecuma acs refrakcijas kḷūda tika mērīta divas reizes gadā. Acs refrakcijas kḷūda tika noteikta pilnā cikloplēgijā (Sol. Cyclopentolate hydrochloride 1\% pa 1 pilienam katrā acī divas reizes ik pēc 5 minūtēm, pēc pilināšanas tiek nogaidīts 30-40 minūtes). Mērījumi tika veikti ar retinoskopu un rokas vai statīva autorefraktometru. Pēc cikloplēǵijas datiem, 2 nedēḷas pēc operācijas tika izrakstītas monofokālas, bifokālas vai progresīvas ametropiju tuvumā un/vai tālumā koriḡējošas brilles. Refrakcijai mainoties, tika mainīts koriğējošo brillıu lēcu stiprums [70, 71, 80]. 


\subsection{Refrakcijas izmaiņas jeb miopiskā novirze acīm ar pseidofakiju}

Miopiskā novirze vai refrakcijas maiņa miopiskā virzienā pēc kataraktas operācijas bērnu vecumā tika rēķināta kā refrakcijas kḷūdas sfēriskā ekvivalenta atšķirība pēdējās izmeklēšanas laikā un pirmajā izmeklēšanā - nedēlu pēc kataraktas ķirurğiskas korekcijas ar intraokulāras lēcas implantāciju [71, 131].

\subsection{Redzes asuma novērtējums un ambliopijas ārstēšana}

Bērniem līdz trīs gadu vecumam labākais korig̣ētais redzes asums tika noteikts ar izvēles skatīšanās testiem, izmantojot Kārdifas aktivitātes kartes (Cardiff Acuity Cards). Vecākiem bērniem tāluma redze tika mērīta ar E burta testu, attēlu tabulas testu, ciparu tabulas testu $5 \mathrm{~m}$ attālumā un Lea testu vai E burta testu tuvumā $(40 \mathrm{~cm})$. Pēc iegūtajiem redzes asuma rezultātiem pēdējā pēcoperācijas izmeklēšanā redze tika novērtēta kā l̦oti laba (5) - Visus 20/25-20/20, laba (4) - Visus 20/40-20/30, vidēja (3) - Visus 20/60 -20/50, zema (2) - Visus 20/100-20/ 200 un l̦oti zema (1) - līdz 20/200. Pirmās divas grupas apvienojot, veidojām vienu grupu, kuras redzes asumu uzskatījām par labu. Tāpat apvienojām divas pēdējās grupas, apzīmējot visus redzes asumus, kas apvienoti šajā grupā, kā zemus. Rezultātā salīdzinājumam izveidojās trīs redzes novērtējuma grupas: labas, vidējas un zemas redzes grupa.

Nepieciešamības gadījumā tika īstenota ambliopijas terapija, veicot veselās vai labāk redzošās acs oklūziju. Bērni regulāri darbojās kopā ar redzes pedagogu, sekmējot bērna un vecāku sapratni par korekcijas līdzekḷa un oklūzijas terapijas nozīmību un iespējām.

\subsection{Statistiskā analīze}

Lai analizētu pacientu demogrāfiskos un klīniskos rādītājus, tika izmantotas aprakstošās statistikas metodes. Normālsadalītos kvantitatīvos rādītājus aprakstīja kā vidējo (M) un standartnovirzi (SD), pretējā gadījumā tika izmantoti mediāna (Me) un starpkvartiļu izkliedes amplitūda ([IQR]). Kvalitatīvie mainīgie tika izteikti kā skaits (N) un procentuālā attiecība (\%). Divu grupu kvantitatīvie dati tika analizēti ar t-testu vai Manna-Vitnija testu, savukārt trīs un vairāk grupas analizēja izmantojot dispersiju analīzi (ANOVA) vai Kraskela-Vollisa testu. Datu sadalījumu izkliedes pārbaudes izmantoja Lēvena testu. Spīrmena (rs) korelācijas koeficienta analīze tika izmantota, lai analizētu sakarības starp nepārtrauktajiem mainīgajiem. Lineārās regresijas analīzi izmantoja kvantitatīvo pazīmju ietekmes izvērtēšanai. Kvalitatīvie dati tika analizēti, izmantojot Pīrsona hī kvadrāta vai Fišera precīzo testu atbilstoši to lietošanas 
nosacījumiem. Divpusēja p-vērtība $<0,05$ tika uzskatīta par statistiski nozīmīgu. Statistiskā analīze tika veikta, izmantojot IBM SPSS programmu (Windows versijai 23, IBM Corp., Somers, NY, ASV). 


\section{REZULTĀTI}

\subsection{Iedzimtas kataraktas raksturojošie lielumi - sākšanās laiks, morfologija, lateralitāte un to savstarpējā saistība}

\subsubsection{Iedzimtas kataraktas sākšanās laika un morfoloğiskā tipa savstarpējā saistība}

Pētot IK sākšanās laika un morfologiskā tipa savstarpējo sakarību, analizējām dažāda sākšanās laika iedzimtas kataraktas morfologiiju. Tas parādīts 3.1. attēlā.
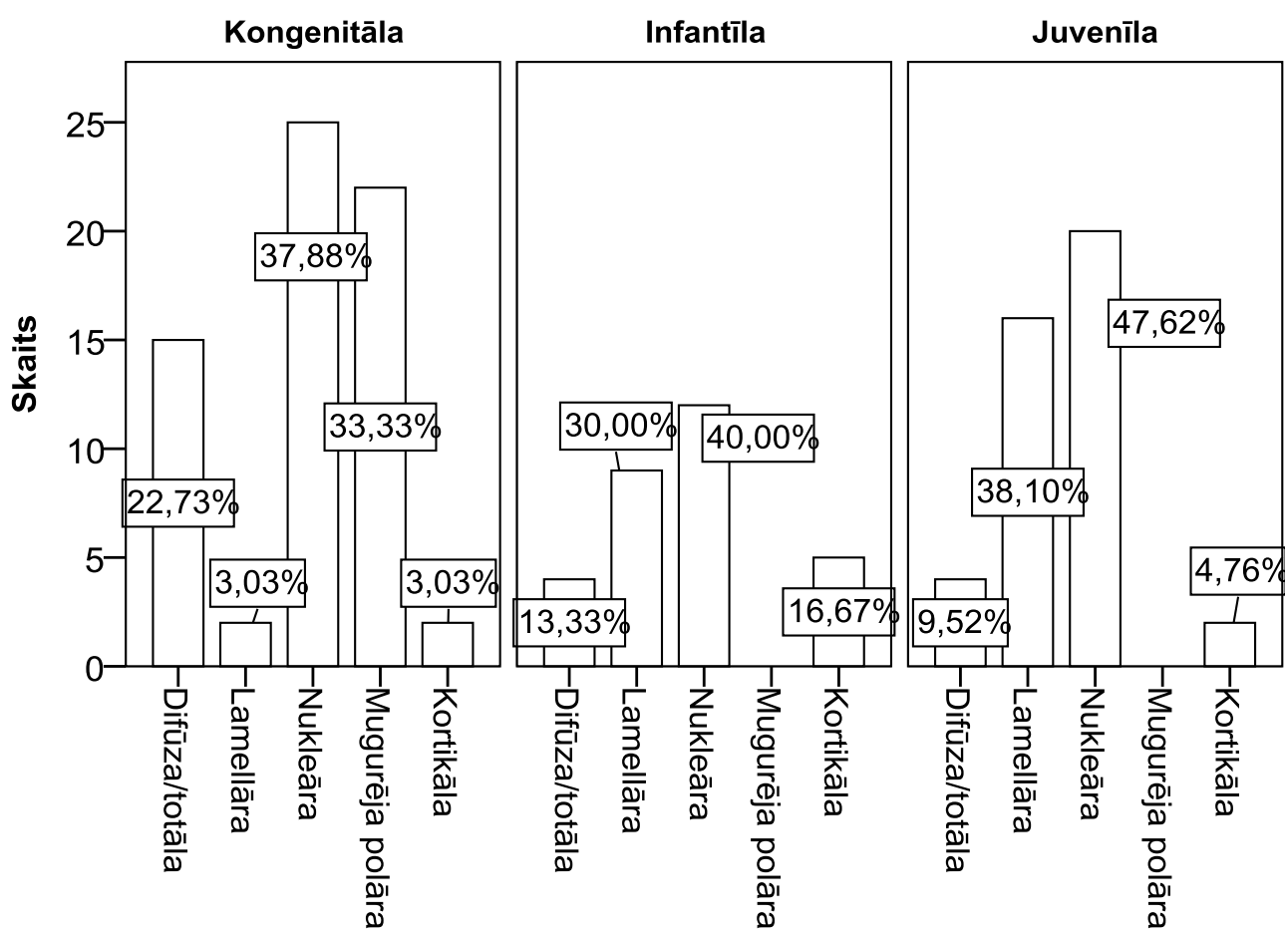

\section{1. att. Dažāda sākšanās laika iedzimtas kataraktas grupu iedalījums pēc kataraktas morfoloğiskā tipa}

Kongenitālajā grupā, kurā bija 66 acis ar pseidofakiju, visbiežāk tika diagnosticēta difūza/totāla - 15 (22,73\%), nukleāra - 25 (37,88\%) un mugurēja polāra - 22 (33,33\%) katarakta. Nukleārā katarakta visbiežāk izpaudās arī infantilajā grupā - 12 (40,00\%) un juvenilajā grupā 20 (47,62\%). Infantilajā grupā kopā bija 30 acis ar pseidofakiju, juvenilajā - 42 acis ar pseidofakiju. Juvenilajā grupā bieži diagnosticēta arī lamelāra katarakta - $16(38,10 \%)$. Kā visretākā tika diagnosticēta kortikālā iedzimtā katarakta, kura kongenitālajā grupā bija 2 (3,03\%), infantilajā grupā - 5 (16,67\%), juvenilajā grupā - 2 (4,76\%) gadījumi.

Salīdzinot kataraktas sākšanās grupu dažādu morfoloğisko kataraktas tipu proporcijas, tika atrastas statistiski nozīmīga proporciju atškirība. Piemēram, mugurējās polārās kataraktas 
daudzuma proporcija statistiski nozīmīgi atšks̄īās gan kongenitālajā un infantilajā grupā, kur Z proporcija starp kongenitālo un infantilo grupu bija 3,6018 ( $\mathrm{p}=0,00032)$, gan kongenitālajā un juvenilajā grupā, kur Z proporcija bija 4,2 (p=0). Salīdzinot kortikālas kataraktas gadījumu skaitu kongenitālajā un infantilajā grupā, Z proporcija bija $-2,4(\mathrm{p}=0,02)$, kas arī parāda statistiski nozīmīgu atšķirību. Citu grupu salīdzinājumos proporciju atšķirīibas nav statistiski nozīmīgas, tomēr tās parāda, ka jebkurā no IK sākšanās laika grupām ir iespējams jebkurš morfologiskais kataraktas variants. Piemēram, nukleārās kataraktas daudzums kongenitālajā un infantilajā grupā statistiski ticami neatšķīrās $-\mathrm{Z}$ proporcija bija $-0,2(\mathrm{p}=0,84)$. Tomēr kopumā šajā datu salīdzinājumā uzskatāmi parādās, ka kataraktas morfologiija dažādos kataraktas sākšanās laikos var būt ļoti dažāda.

\subsubsection{Iedzimtas kataraktas sākšanās laika un lateralitātes savstarpējā saistība}

Pētot IK lateralitāti dažāda kataraktas sākšanās laika grupās, tika iegūti šādi rezultāti, kas atspoguloti 3.2. attēlā.

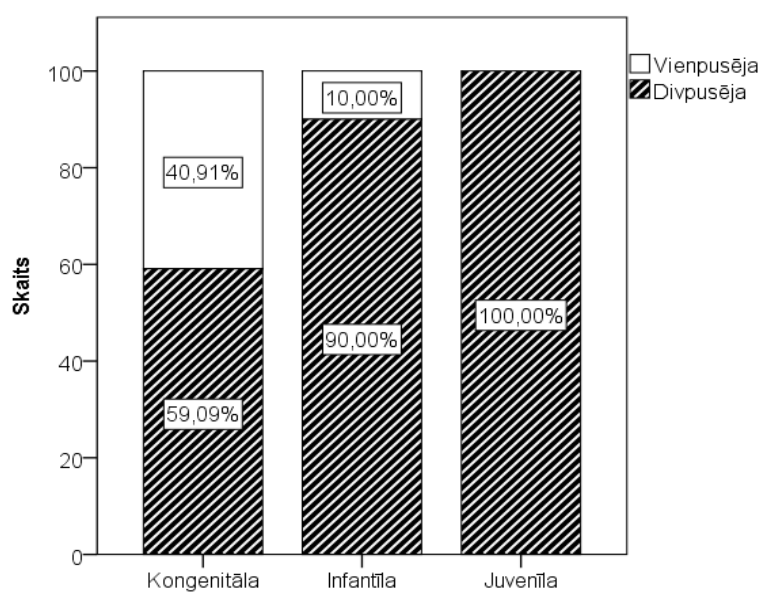

\section{2. att. Kataraktas iedalījums pēc lateralitātes kataraktas sākšanās laika grupās}

Kongenitālajā grupā tika diagnosticēta gan vienpusēja (40,91\%), gan divpusēja (59,09\%) katarakta. Infantilajā grupā salīdzinoši vienpusēja katarakta bija daudz retāk, tika diagnosticētas tikai trīs vienpusējas kataraktas acis (10\%). Juvenilajā grupā bija tikai divpusējas kataraktas acis (100\%). Salīdzinot vienpusējas kataraktas daudzumu kongenitālajā un infantilajā grupā, Z proporcija ir 3,02 (p =0,002), kas liecina par statistiski nozīmīgu atšķirību. Tā kā juvenilajā grupā netika diagnosticēta neviena vienpusēja katarakta, arī šeit Z proporcijas tests liecina par statistiski ticamu atšksirību. 


\subsubsection{Iedzimtas kataraktas morfoloğiskā tipa un lateralitātes savstarpējā saistība}

Pētot dažādu morfolog̣isko kataraktas tipu lateralitāti, redzam, ka difūza/totāla katarakta 91,30\% gadījumu ir abpusēja, lamelāra katarakta mūsu pētījuma izlasē 100\% bija abpusēja, 84,21\% nukleāras kataraktas gadījumu bija abpusēja katarakta. Mugurējā polārā katarakta 68,18\% gadījumu bija vienpusēja, kortikāla katarakta 44,44\% gadījumu bija vienpusēja (3.3. att.).

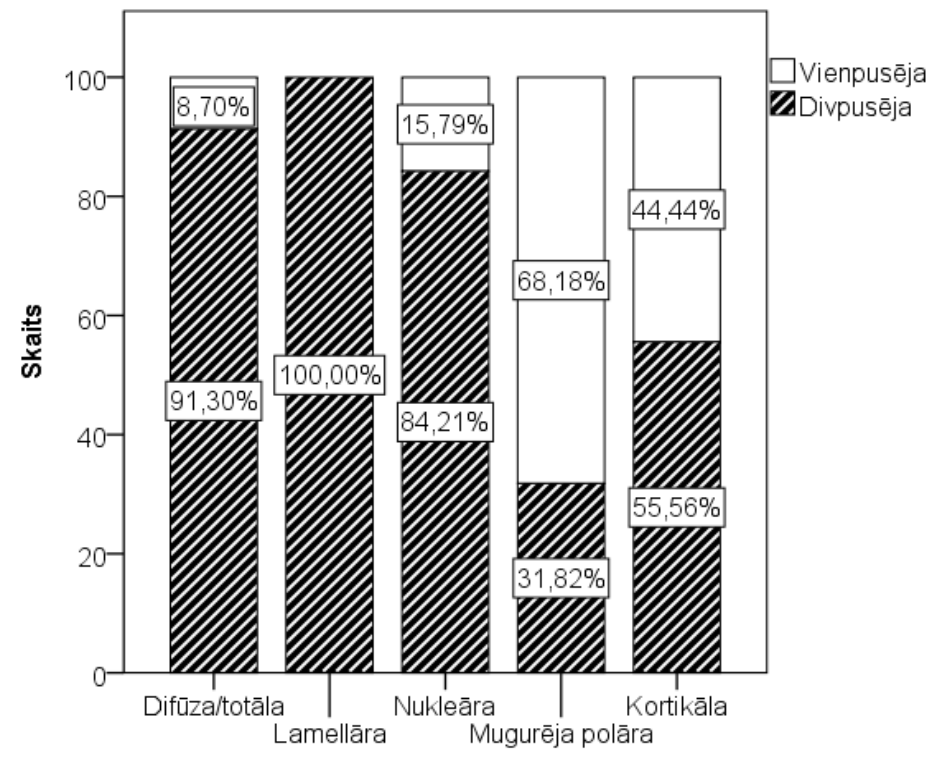

\section{3. att. Iedzimtas kataraktas morfoloğisko tipu iedalījums pēc lateralitātes}

Salīdzinot vienpusējas kataraktas biežumu dažādos kataraktas morfologiiskajos variantos, tika atrastas vairākas statistiski ticamas proporciju atšķirības. Piemēram, salīdzinot difūzu/totālu un mugurējo polāro kataraktu, Z proporcija attiecībā pret vienpusējas un abpusējas kataraktas acu skaitu šajās grupās bija $-2,33(\mathrm{p}=0,02)$, kas parāda statistiski ticamu atšķirību. Tāpat statistiski ticama būs $\mathrm{Z}$ proporcijas atšķirība starp totālas difūzas un kortikālas kataraktas lateralitātēm. Taču, salīdzinot totālas/difūzas un nukleāras kataraktas lateralitātes, $Z$ proporcija ir $-0,8339(\mathrm{p}=$ 0,406), kas statistiski ticamu atšķirību neparāda. Tomēr varam teikt, ka vienpusējas un abpusējas kataraktas morfologija atšķiras un ir dažāda. 


\subsection{Iedzimtas kataraktas ārstēšanas laiki, to saistība ar dažādiem iedzimtas kataraktas iedalījumiem un ārstēšanas komplikācijām}

\subsubsection{Iedzimtas kataraktas primārās ķirurğiskās korekcijas laiks dažādiem kataraktas morfoloğiskajiem tipiem}

Izpētot un analizējot iedzimtas kataraktas morfologiisko uzbūvi, ņemot vērā kataraktas sākšanās laiku un lateralitāti, tiek pieņemts lēmums par iedzimtas redzei nozīmīgas kataraktas ķirurǵiskās korekcijas laiku. Analizējot bērna vecumu kataraktas operācijas laikā un kataraktas morfoloǵisko dažādību, tika iegūti dati, kas parādīti 3.4. attēlā.

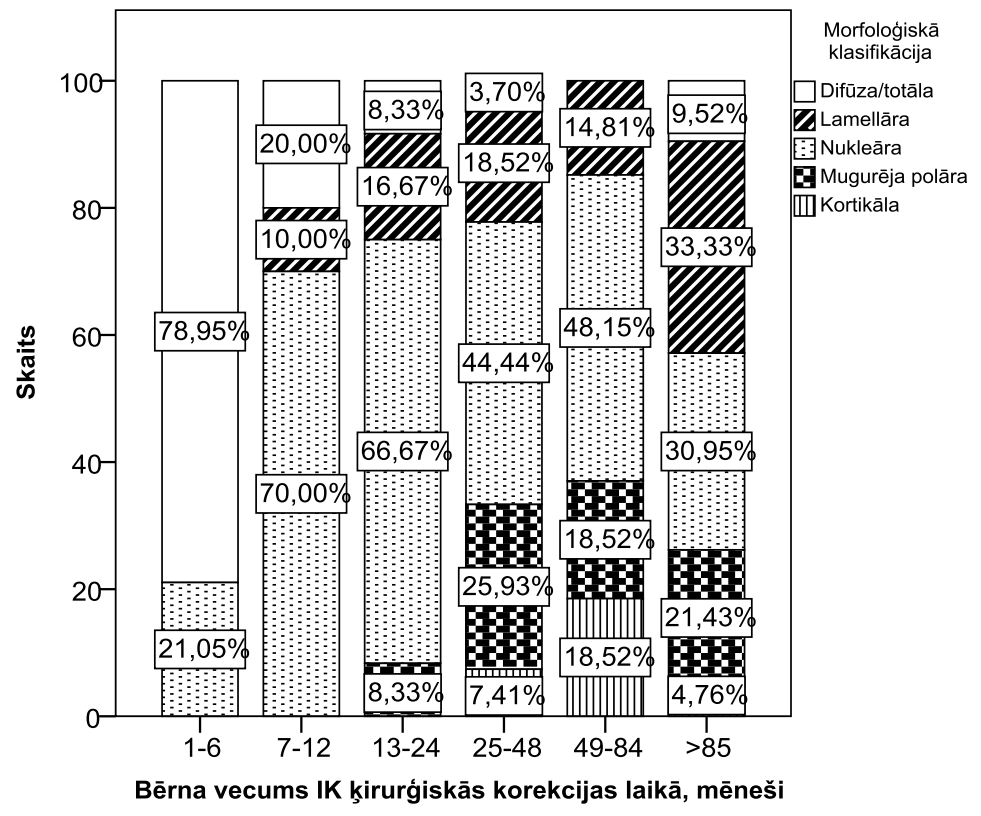

\section{4. att. Dažādos vecumos operētas iedzimtas kataraktas iedalījums pēc kataraktas morfologiskā tipa}

Agrīni - no bērna viena līdz sešiem mēnešiem - tika operēta tikai difūza/totāla un nukleāra katarakta. Palielinoties pacientu vecumam, operēto totālas/difūzas kataraktas gadījumu skaits samazinājās, pieaugot citu iedzimtas kataraktas morfologisko tipu operēto acu skaitam. Morfoloǵisko tipu proporcijas dažādos bērnu vecumos operētai IK statistiski ticami atš̌s̄īās (p < 0,001). Mugurējā polārā katarakta mūsu izlasē tika operēta pēc 12 mēnešu vecuma. Vecumā no četriem līdz astoņiem gadiem nebija operēta neviena difūza/totāla katarakta, bet vecumā pēc astoṇiem gadiem bija operēti visi sastopamie morfologiskie kataraktas tipi, skat 3.4. attēlu. 


\subsubsection{Iedzimtas kataraktas primārās ķirurğiskās korekcijas laiks dažādām kataraktas lateralitātes grupām}

Bērna vecums vienpusējas un abpusējas kongenitālas IK primārās ķirurǵiskās korekcijas laikā atspogulıots 3.5. attēlā.

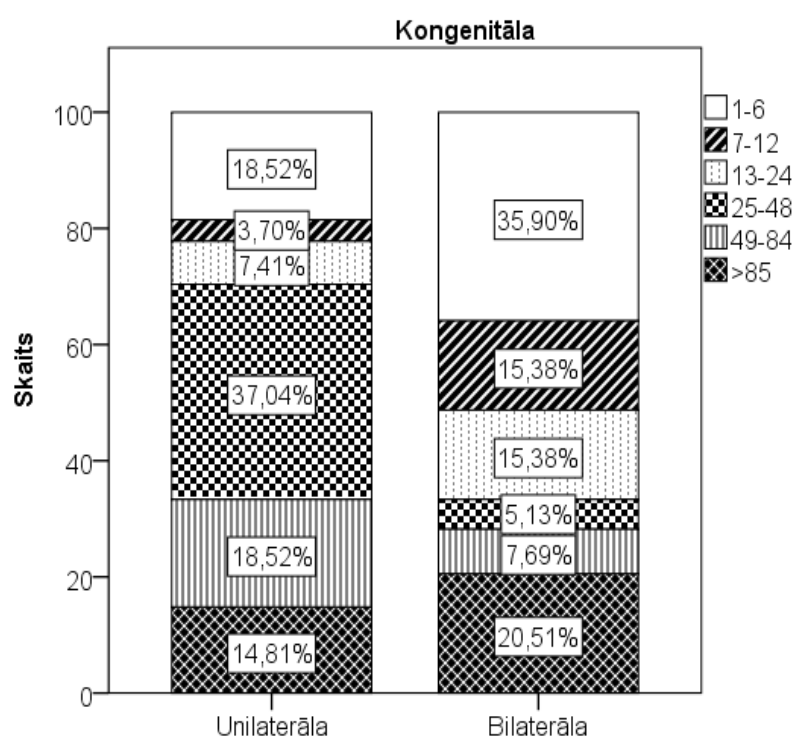

\section{5. att. Kongenitālas vienpusējas un abpusējas iedzimtas kataraktas primārās operatīvās ārstēšanas laiks}

Kongenitālas abpusējas iedzimtas kataraktas tika operētas visos bērna vecumos. Kongenitālas vienpusējas kataraktas arī tika operētas visos bērna vecumos. Salīdzinot bērnu vecumu primārās ķirurǵiskās korekcijas laikā, statistiski ticamas proporciju atšķirības ar Z proporciju testu tika atrastas tikai vienā bērnu vecuma grupā - no 25 mēnešiem līdz 48 mēnešiem, kur Z proporcija ir 3,3045 ( $\mathrm{p}=0,00096)$. Citās grupās statistiski ticamas proporciju atšksirības netika novērotas. Tomēr dažādais primārās operācijas laiks arī uzskatāmi parāda iedzimtas kataraktas dažādību.

\subsubsection{Sekundāra glaukoma un tās biežums dažādos iedzimtas kataraktas ķirurğiskas korekcijas laikos atbilstoši acs augšanas periodiem}

Lai analizētu sekundāras glaukomas biežumu, mēs izvēlējāmies bērna vecumu primārās ķirurǵiskās korekcijas un IOL implantācijas laikā apskatīt saistībā ar acs augšanas fāzēm. Analizējot sekundāras glaukomas biežumu dažādos acs augšanas periodos, tika iegūti dati, kas attēloti 3.6. attēlā. 


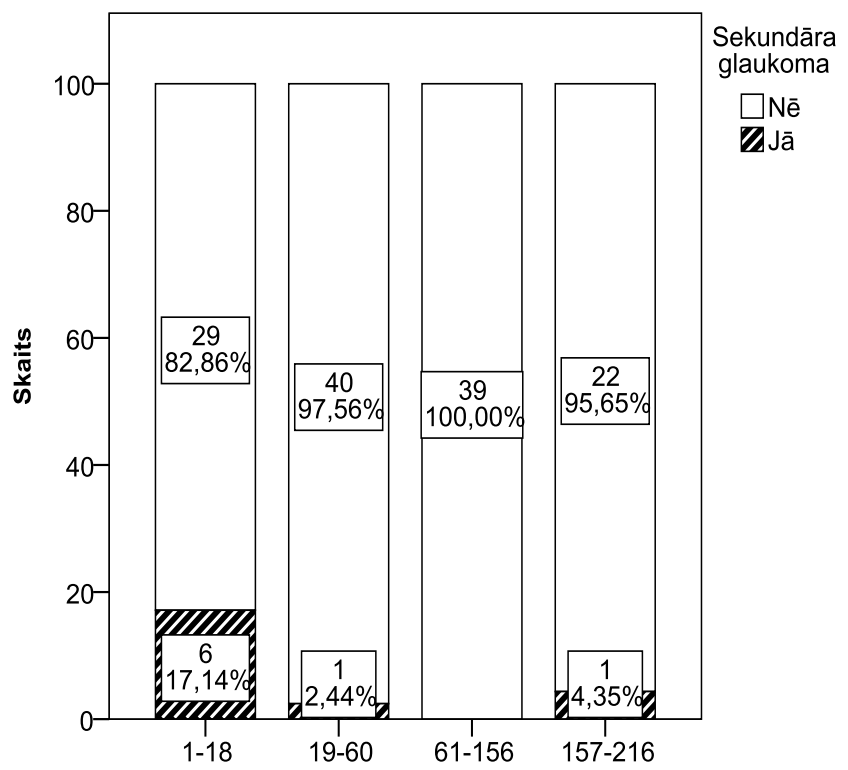

3.6. att. Sekundāras glaukomas biežums acīm ar iedzimtu kataraktu un pseidofakiju, kuras operētas dažādos acs augšanas periodos

Analizējot sekundāras glaukomas biežumu visā pētījuma izlasē, SG tika diagnosticēta 8 $(15,2 \%)$ acīs. Salīdzinot acs augšanas periodus, visbiežāk sekundāra glaukoma tika konstatēta acīs, kas bija operētas postnatālajā ātrajā acs augšanas fāzē - laikā līdz bērna 18 mēnešiem (77,8\% no visiem sekundāru glaukomu gadījumiem). Salīdzinot sekundāras glaukomas proporciju ātrajā augšanas fāzē un infantilajā lēnajā augšanas fāzē, tika iegūta statistiski ticama atšksirība $(Z$ proporcija $=2,6638, p=0,007)$, salīdzinot arī ar juvenilo lēno acs augšanas fāzi $(Z$ proporcija $=2,039, \mathrm{p}=0,04)$ un periodu, $\operatorname{kad}$ acs vairs neaug $(\mathrm{Z}$ proporcija $=2,1409, \mathrm{p}=0,03)$, sekundāras glaukomas biežuma proporcijas atšķirības bija statistiski ticamas.

\subsubsection{Sekundāra katarakta un tās biežums dažādos iedzimtas kataraktas operācijas laikos atbilstoši dažādiem izmantotajiem operācijas veidiem}

Lai analizētu sekundārās kataraktas biežumu, mēs izvēlējāmies bērna vecuma periodus, kad IK ķirurǵiskai korekcijai tiek izmantotas dažādas kataraktas ekstrakcijas modifikācijas, kas sīkāk aprakstītas pētījuma materiālos un metodēs.

Analizējot pētījuma izlases acis ar pseidofakiju, sekundāra katarakta (sekundāras kataraktas un/vai optiskās ass reproliferācijas) tika diagnosticēta visos IK ārstēšanas periodos. Kopējā izlasē sekundāra katarakta tika diagnosticēta 58 (42,65\%) acīs. Kā redzams 3.7. attēlā, grupā, kurā acu operācija izdarīta laikā no bērna viena līdz 24 mēnešiem, veicot kataraktas 
ekstrakciju, mugurējo kapsuloreksi un priekšējo vitrektomiju, sekundāra katarakta tika konstatēta 17 acīs $(41,46 \%)$. Laika periodā no 24 mēnešu vecuma līdz 84 mēnešu vecumam, kad tiek veikta kataraktas ekstrakcija un mugurējā kapsulorekse, pēcoperācijas periodā sekundāra katarakta tika konstatēta 26 acīs $(48,1 \%)$, laikā pēc bērna 84 mēnešu vecuma, kad tiek veikta tikai kataraktas ekstrakcija, sekundāra katarakta tika diagnosticēta 13 acīs (32,5\%) (3.7. att.).

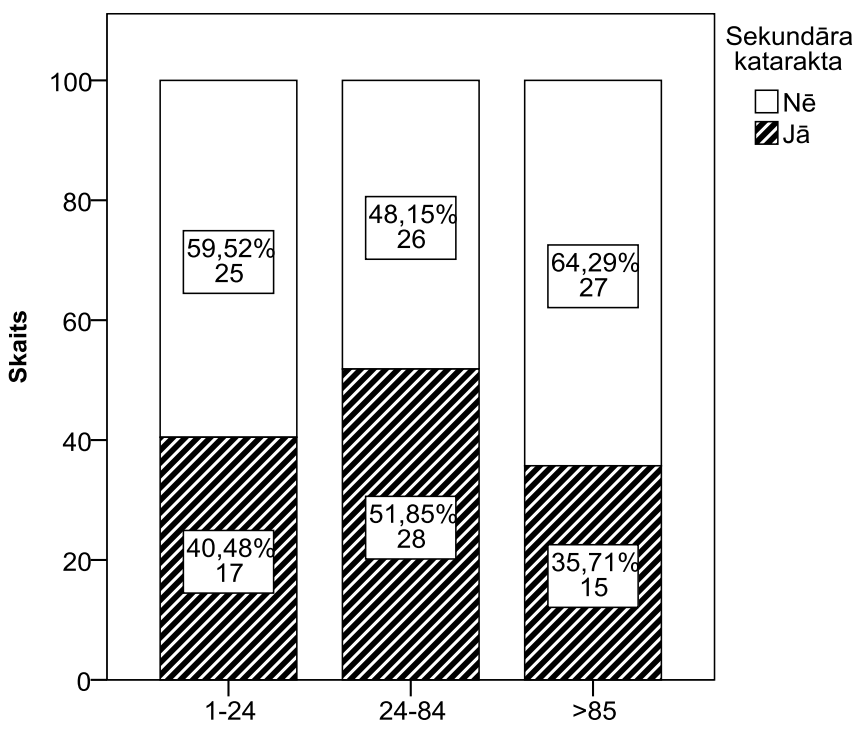

\section{7. att. Sekundāras kataraktas biežums acīm ar iedzimtu kataraktu un pseidofakiju, kuras operētas ar dažādām metodēm dažādos vecuma periodos}

Salīdzinot sekundāras kataraktas proporciju bērniem, kas operēti ar dažādām metodēm un dažādos vecuma periodos, netika iegūta statistiski ticama proporciju atšķirība $(Z$ proporcija $=$ $-0,6483, p=0,5$, analizējot 1. un 2. grupu, $Z$ proporcija $=0,8352, p=0,4$, analizējot 1 . un 3 . grupu, $Z$ proporcija $=1,5224, p=0,128$, analizējot 2. un 3. grupu). Arī Pīrsona hī kvadrāta statistiskā testa analīzē starp dažādu operācijas veidu un dažāda bērnu vecuma grupām un sekundārās kataraktas biežumu netika konstatēta statistiski ticama atšķirība $(p=0,16)$.

\subsection{Acs refrakcijas izmaiṇas - acs miopiskā novirze acīs ar pseidofakiju, to ietekmējošie faktori}

Kataraktas ķirurǵiska korekcija ar intraokulārās lēcas implantāciju izjauc acs refrakcijas dabisko emetropizāciju. Bērna acs ābolam augot, acs refrakcijas kḷūda mainās miopiskā virzienā. Pētîjumā tika pētīta refrakcijas kḷūdas jeb miopiskās novirzes lielums acīm ar pseidofakiju un tā saistība ar 1) bērna vecumu ķirurǵiskas korekcijas laikā, 2) dažādiem acs augšanas periodiem, 3) 
iedzimtas kataraktas morfoloǵiskajiem tipiem, 4) iedzimtas kataraktas lateralitāti, 5) dažādām intraokulārās lēcas implantācijas mērksa refrakcijas taktikām, 6) katras acs implantēto individuālo IOL stiprumu un 7) pēcoperācijas komplikācijām.

\subsubsection{Pseidofakiskas acs refrakcijas izmaiṇu - miopiskās novirzes salīdzinājums dažādās iedzimtas kataraktas ķirurğiskas korekcijas bērna vecuma grupās un dažādos acs augšanas periodos}

Acs refrakcijas izmaiņu atšķirības atkarībā no lensektomijas un intraokulāras lēcas implantācijas laika parādītas 3.8. A un B attēlā. Salīdzinot ARI vai MN maksimālā novērošanas periodā operētām IK acīm, kas operētas sešos atšķirīgos bērna vecumos, novērojām, ka acīs, kuras operētas agrīni (no viena līdz sešu mēnešu vecumā), līdzīgos novērošanas periodos ARI ir statistiski nozīmīgi lielākas nekā acīm, kas operētas vēlākā vecumā $(\mathrm{p}<0,05)$. Kā redzams 3.8. A attēlā, miopiskās novirzes mediāna grupā, kas operēta no viena līdz sešiem mēnešiem, ir -7,75 D, nākamajā kataraktas operācijas bērnu vecuma grupā (7-12 mēneši) mediāna samazinās gandrīz trīs reizes, sasniedzot -2,62 D. Salīdzinot otro un trešo grupu, kas ietver acis, kuras tiek operētas līdz 24 mēnešu vecumam, miopiskās novirzes attīstība šajās grupās praktiski nemainās (MS mediāna $=-2,87$ D). Ja iedzimtā katarakta tiek operētas bērna vecumā no 25 mēnešiem līdz 18 gadiem, miopiskās novirzes mediāna tuvojas nullei.
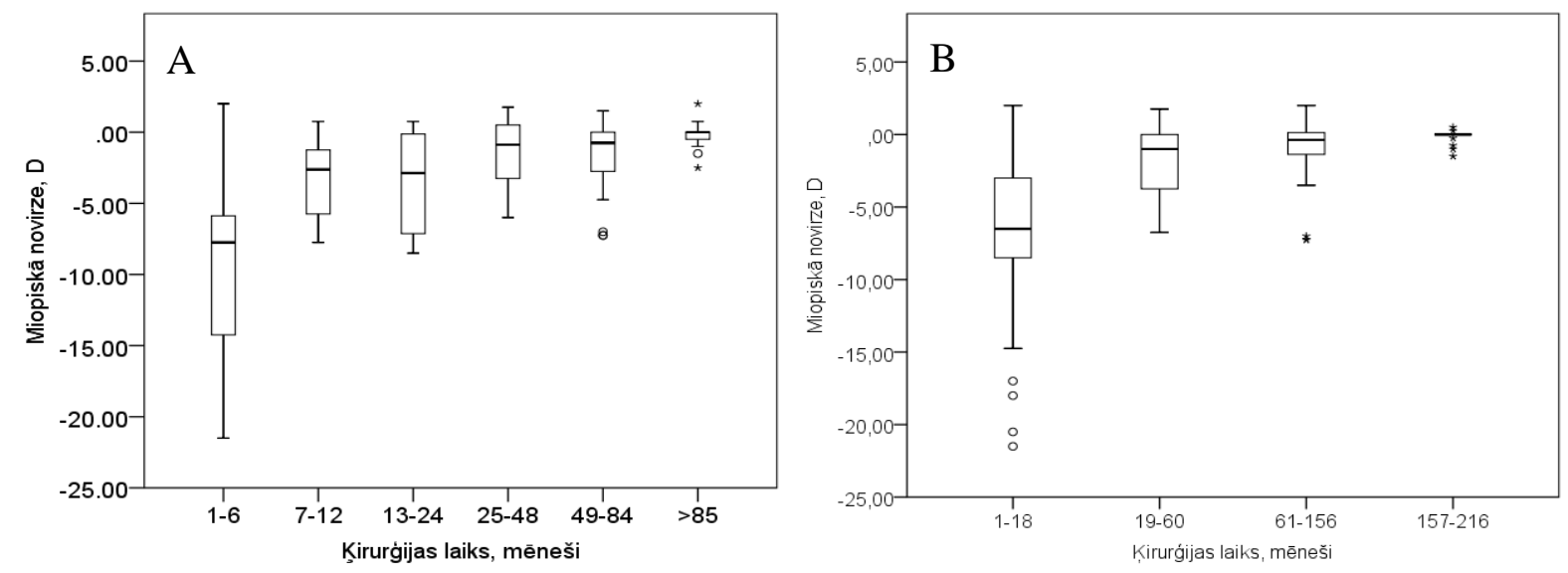
3.8. A un B att. Pseidofakiskas acs refrakcijas izmaiṇu salīdzinājums iedzimtas kataraktas
ķirurğiskas korekcijas bērna vecuma grupās un dažādos acs augšanas periodos 

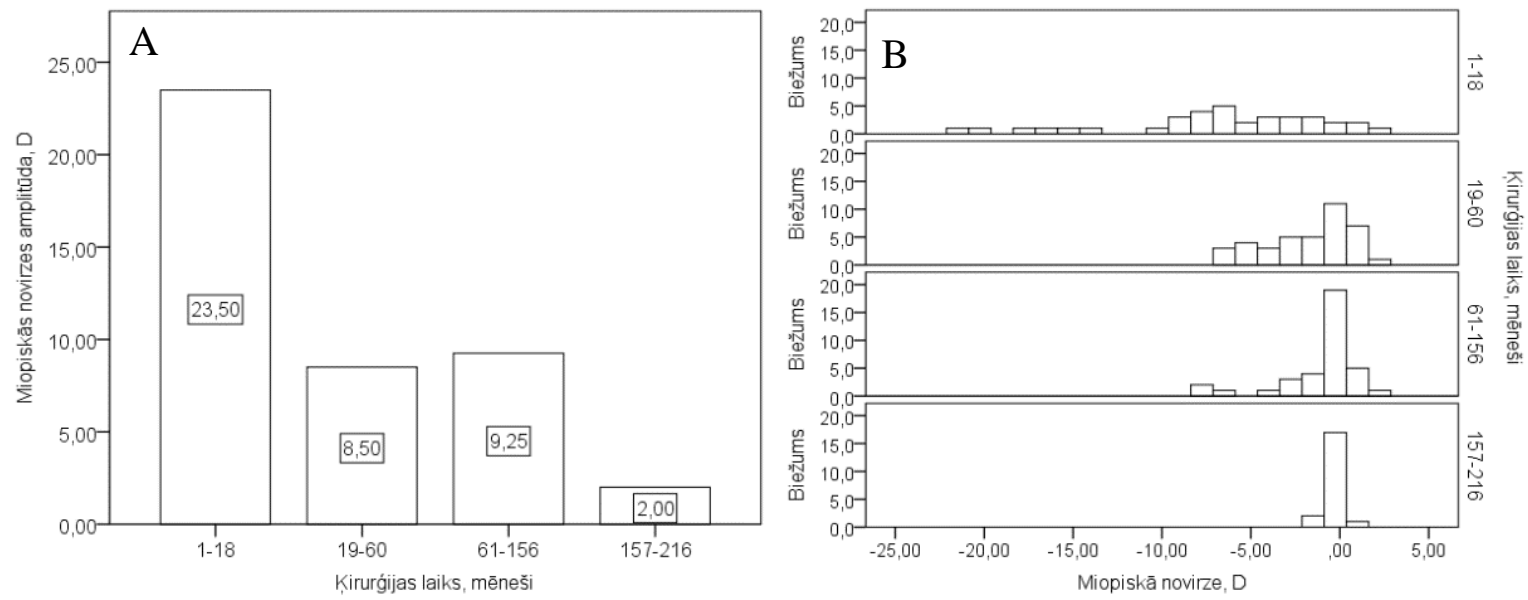

3.9. A un B att. Acs refrakcijas izmaiṇu jeb miopiskās novirzes salīdzinājums

A - miopiskās novirzes amplitūdu salīdzinājumi;

B - miopiskās novirzes histogrammas dažādās acs augšanas fāzēs

Salīdzinot ARI vai MN izkliedes jeb dispersijas dažādos acs augšanas periodos, kas parādīti 3.8. B un 3.9. A attēlā, novērojām, ka vislielākā dispersijas amplitūda novērojama ātrajā acs augšanas fāzē laikā no viena līdz 18 mēnešiem (23,5 D), kamēr laikā, kad acs vairs neaug (157-216 mēneši), MN dispersijas amplitūda ir 2D. Analizējot acs refrakcijas izmaiņu dispersijas dažādās acs augšanas fāzēs, ARI dispersija postnatālajā ātrajā acs augšanas fāzē statistiski ticami atšksiras no pārējām acs augšanas fāzēm - infantilās un juvenilās lēnās augšanas fāzes un perioda, kad acs augšana vairs nenotiek (Lēvena tests, $\mathrm{p}<0,05$ ). Abās lēnajās acs augšanas fāzēs refrakcijas izmaiņas acīm ar pseidofakiju statistiski ticami neatšksiras (p > 0,05). Salīdzinot RI acīm, kas operētas lēnajās acs augšanas fāzēs (19-60 mēnešos un 61-156 mēnešos) un laikā, kad acs vairs neaug (157-216 mēneši), starp MN 2. un 4. grupā un 3. un 4. grupā tika iegūtas statistiski ticamas atšķirības (Lēvena tests, $\mathrm{p}<0,01$ ). Acs refrakcijas izmainu jeb miopiskās novirzes dispersijas dažādos acs augšanas periodos atspoguḷotas 3.9. B attēlā.

\subsubsection{Acs refrakcijas izmaiṇu - miopiskās novirzes korelācija ar iedzimtas kataraktas acs aksiālo garumu kataraktas ekstrakcijas un intraokulārās lēcas implantācijas laikā}

Bērnam augot, pirmo divu gadu laikā izteikti palielinās tā acs aksiālais garums. Salīdzinot miopiskās novirzes lielumu maksimālajā novērošanas laikā un acs aksiālo garumu kataraktas ekstrakcijas un IOL implantācijas laikā, tika novērota statistiski ticama korelācija - rs = 0,30; $\mathrm{p}=0,01$ (3.10. att.). 


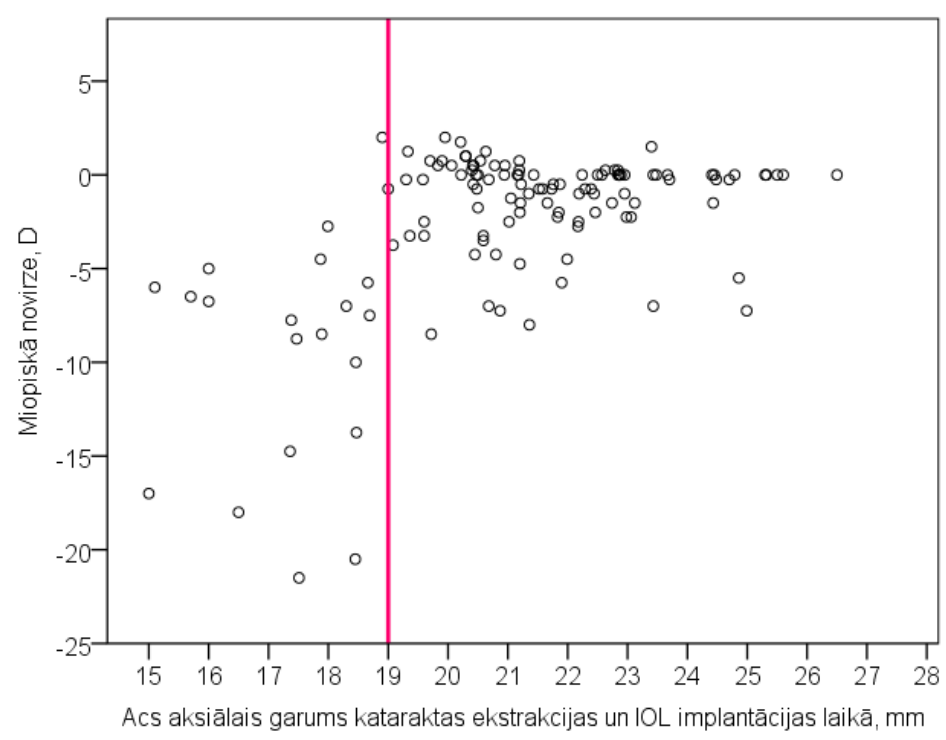

\subsection{0. att. Pseidofakiskas acs miopiskās novirzes lieluma un acs aksiālā garuma salīdzinājums primāras ķirurğiskas korekcijas laikā}

Izvērtējot miopiskās novirzes standartnovirzes acīm ar pseidofakiju un dispersijas acīm ar dažādu garumu iedzimtas kataraktas ķirurǵiskas korekcijas un intraokulāras lēcas implantācijas laikā, ievērojām sakarību, ka MN IK acu grupā, kuru acs aksiālais garums ir mazāks par 19 mm, ir lielāka un atšksiras no MN acīm, kuru aksiālais garums ir vienāds un lielāks par 19 mm ( 3.11 . A un B att.).
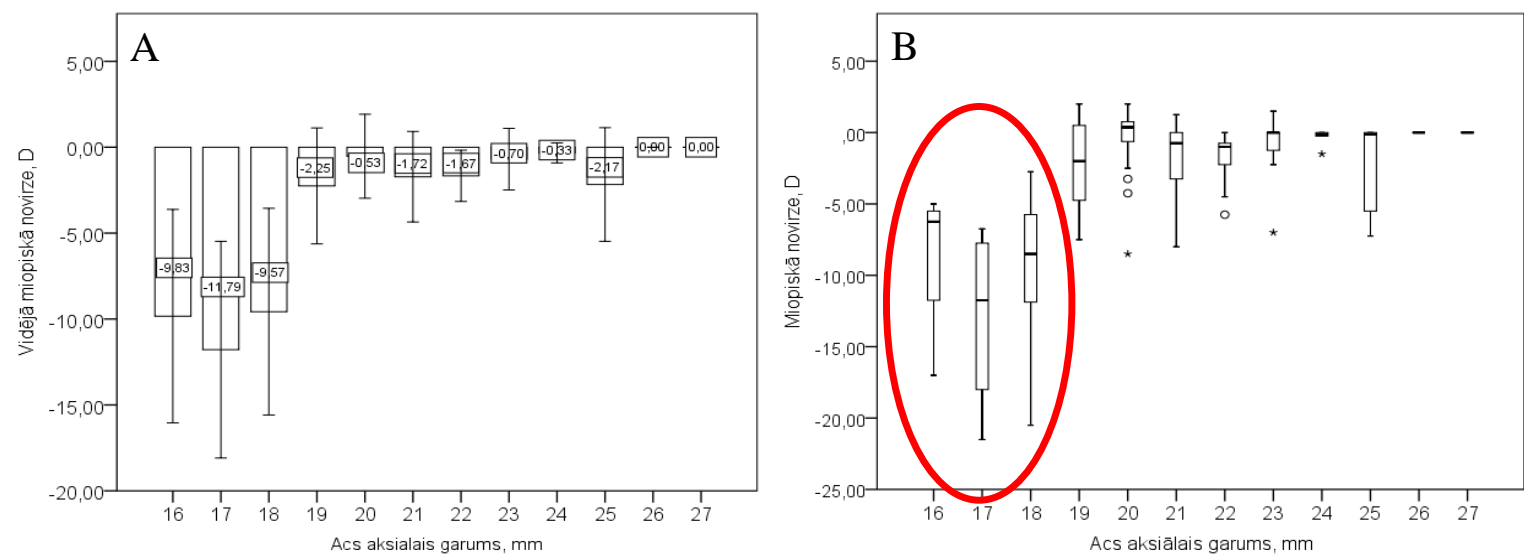

\subsection{A un B att. Miopiskā novirze:}

A - standartnovirzes, mediānas;

B - miopiskās novirzes dispersiju saistība ar IK acu aksiālajiem garumiem

Salīdzinot miopiskās novirzes lielumu acīm, kas ir $<19$ mm, un acīm, kuras $\geq 19$ mm, ieguvām rezultātus, kas attēloti 3.12. attēlā. 


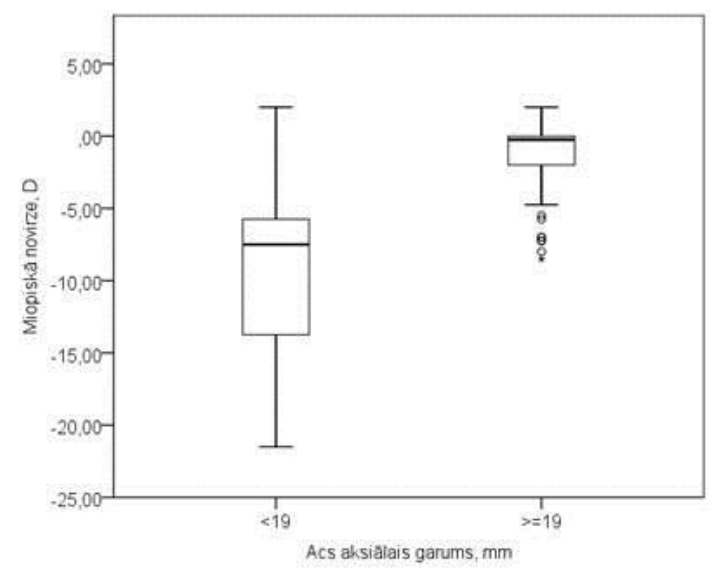

\subsection{2. att. Refrakcijas izmainu jeb miopiskās novirzes lielumu salīdzinājums acīm ar pseidofakiju, kuru aksiālais garums $<19 \mathrm{~mm}$ un $\geq 19 \mathrm{~mm}$}

Acīm, kam aksiālais garums bija $<19 \mathrm{~mm}$, miopiskās novirzes mediāna bija $-7,5 \mathrm{D}$ [-5,37 līdz $-14,25]$, bet acīm, kuru aksiālais garums bija $\geq 19 \mathrm{~mm}$, miopiskās novirzes mediāna bija $-0,25 \mathrm{D}$ [0 līdz $-2,00 \mathrm{D}]$. Pārbaudot miopiskās novirzes dispersijas acu grupām, kuru aksiālais garums bija $<19 \mathrm{~mm}$ un $\geq 19 \mathrm{~mm}$, tika konstatēts, ka tās statistiski ticami atšķiras (Lēvena tests, $\mathrm{p}<0,001$ ).

\subsubsection{Acs refrakcijas izmainu jeb acs miopiskās novirzes salīdzinājumi kataraktas sākšanās un kataraktas morfoloğiskās klasifikācijas grupās}

Miopiskā novirze acīm ar pseidofakiju statistiski ticami atšķīās atkarībā no kataraktas sākšanās laika un morfologískās grupas, sk. 3.13. A un B attēlu.

Kongenitālajā grupā 75\% acu miopiskās novirzes diapazons bija no +2,0 D līdz -7,75 D, 25\% acu MN diapazons bija no -7,75 D līdz-21,5 D. MN diapazons un vidējā vērtība statistiski ticami atšķ̄īās kongenitālās grupas pacientu acīm no infantilās un juvenilās grupas pacientu acīm (ANOVA, $\mathrm{p}<0,05$ ). Infantilajā un juvenilajā grupās MN diapazons un vidējā vērtība bija daudz mazāki (3.13. A att.). Salīdzinot morfoloǵiskās iedzimtas kataraktas grupas (3.13. B att.), MN lielums totālas/difūzas kataraktas morfologijas grupā bija ievērojami lielāks un statistiski ticami atšķīrās no MN lamelārajā, nukleārajā un mugurējā polārajā morfoloǵijas grupā $(\mathrm{p}<0,05)$.

Savukārt miopiskās novirzes lielumi lamelārajā, nukleārajā un mugurējā polārajā morfolog̣iskajā grupā savā starpā statistiski ticami neatšķīās ( $(\mathrm{p}>0,05)$. 

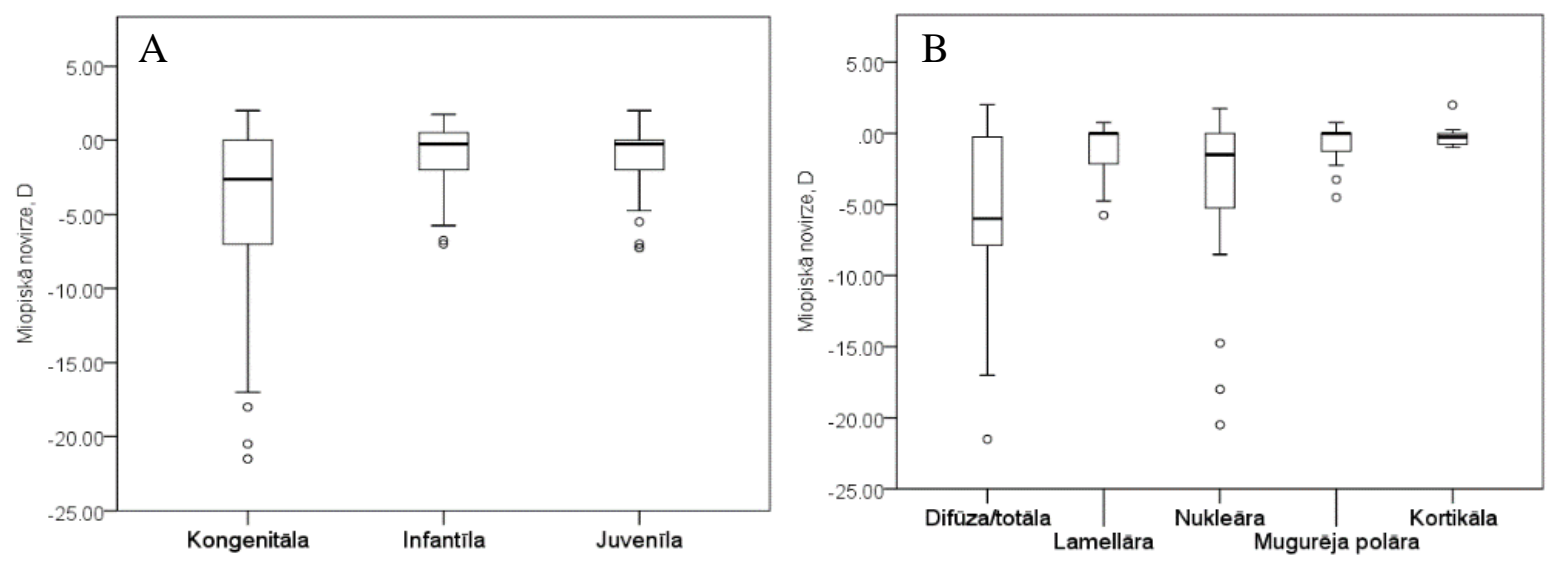

3.13. A un B att. Miopiskās novirzes salīdzinājums

A - kataraktas sākšanās laika klasifikācijas grupās;

B - kataraktas morfologiiskās klasifikācijas grupās

Lai nošķirtu kataraktas sākšanās laika ietekmi no morfoloǵiskās dažādības ietekmes, mēs atsevišķi analizējām morfoloǵiski dažādās kataraktas grupas dažādos kataraktas sākuma periodos (3.14. A, B un C att.).
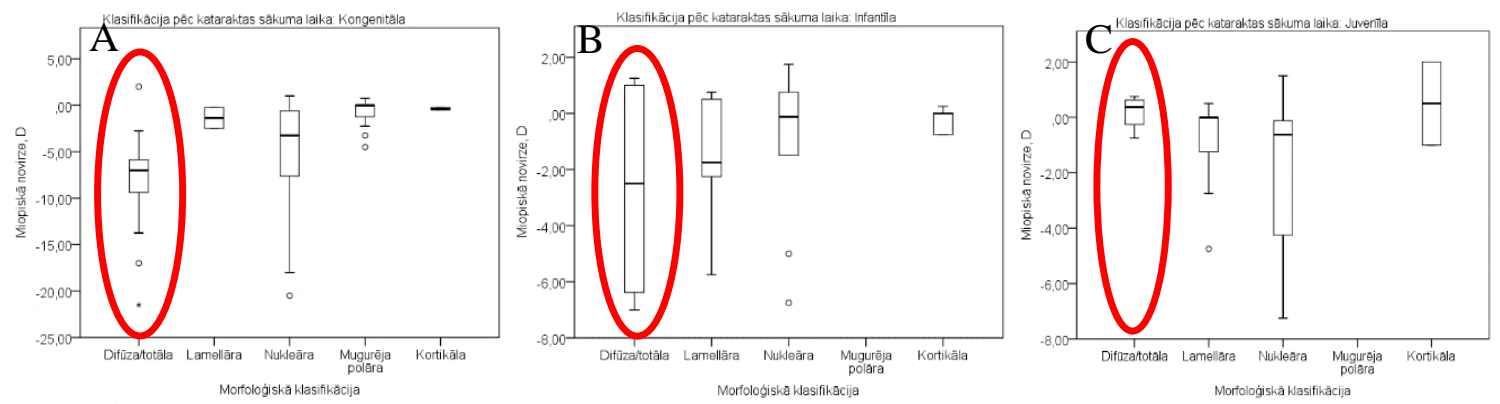

\subsection{A, B un C att. Totālas/difūzas iedzimtas kataraktas salīdzinājums grupās ar dažādu kataraktas sākšanās laiku: \\ A - kongenitālā grupā, B - infantilā grupā, $\mathrm{C}$ - juvenīlā grupā}

Kraskela-Vollisa statistiskā testa analīzē totālas/difūzas IK morfologijas gadījumā miopiskā novirze dažādās kataraktas sākšanās laika grupās - kongenitālā, infantilā un juvenilā statistiski ticami atšķiras $(\mathrm{p}=0,01)$ (3.14. A, B, C attēls). Analizējot iedzimtas kataraktas lamelāras morfolog̣ijas gadījumus, Kraskela-Vollisa statistiskā testa analīzē acs miopiskās novirzes dažāda kataraktas sākšanās laika grupās statistiski ticami neatšksiras $(p=0,63)(3.15$. A, B, C att.). 
A

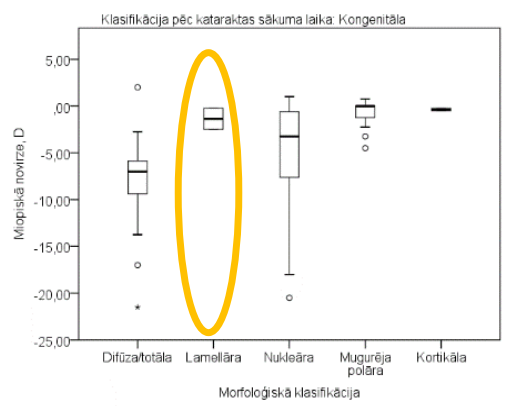

B

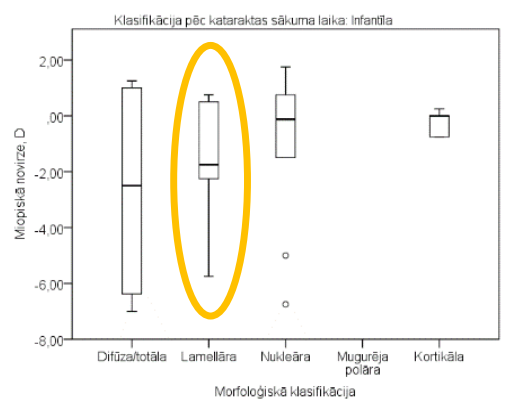

C

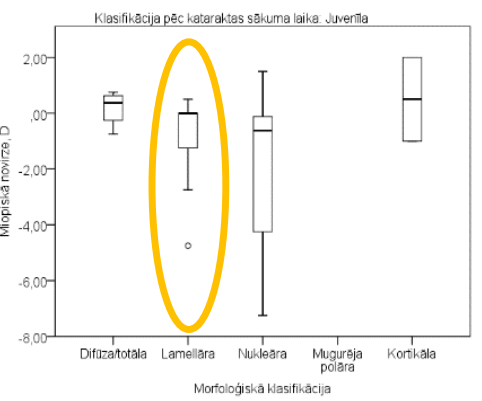

\subsection{A, B un C att. Lamelāras iedzimtas kataraktas salīdzinājums grupās}

ar dažādu kataraktas sākšanās laiku:

A - kongenitālā grupā, B - infantilā grupā, $\mathrm{C}$ - juvenilā grupā

Analizējot nukleāru iedzimtu kataraktu dažādās IK sākšanās laika grupās, MN mediānas un dispersijas attēlotas 3.16. A, B un C attēlā.

A

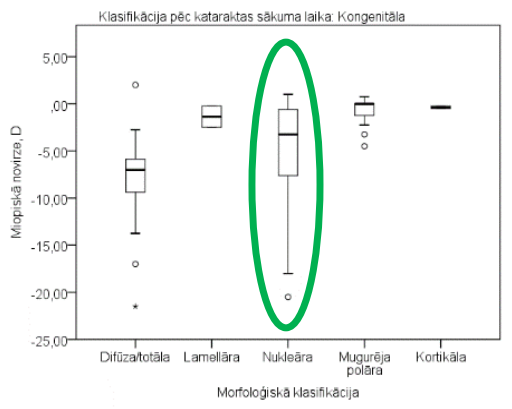

$\mathrm{B}$

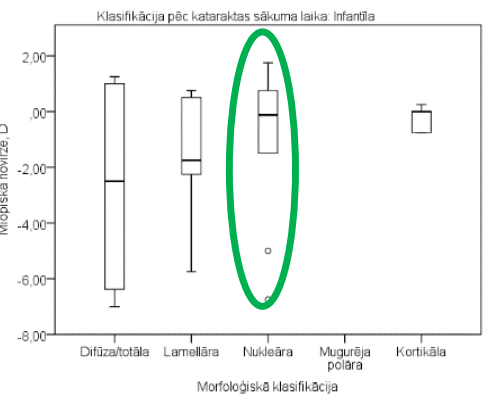

$\mathrm{C}$

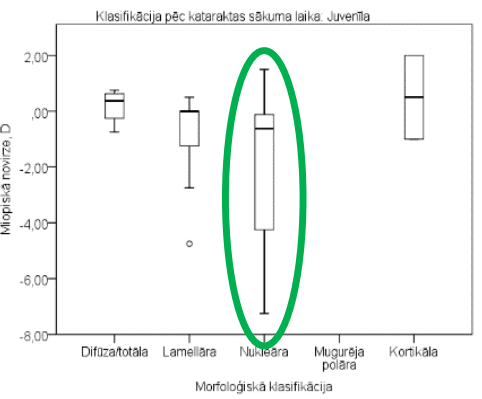

\subsection{A, B un C att. Nukleāras iedzimtas kataraktas salīdzinājums dažāda kataraktas sākšanās laika grupās: \\ A - kongenitālā grupā, B - infantilā grupā, $\mathrm{C}$ - juvenilā grupā}

Kraskela-Vollisa statistiskā testa analīzē nukleārai IK morfologijai miopiskā novirze dažāda kataraktas sākšanās laika grupās statistiski ticami atšksiras (p = 0,01). Lēvena statistiskā testa analīzēe, pārbaudot miopiskās novirzes dispersijas nukleārai iedzimtai kataraktai starp kongenitālā un infantilā sākšanās laika grupām, tika iegūta statistiski ticama dispersiju atšķirība $(\mathrm{p}=0,02)$. Ar̄̄ starp kongenitālās un juvenilās grupas nukleāras kataraktas miopijas noviržu dispersijām tika atrasta statistiski ticama atšķirība $(p=0,04)$. Starp infantilās un juvenilās grupas nukleārās kataraktas miopisko noviržu dispersijām statistiski ticama atšksirība netika atrasta (p = 0,37) (3.16. A, B, C att.). 
Visi mugurējās polārās kataraktas gadījumi tika diagnosticēti vai atzīti par kongenitāliem, tāpēc salīdzināšana nebija iespējama. Kortikālas kataraktas gadījumu skaits katrā IK sākšanās laika grupā ir ļoti mazs, līdz ar to analīze nebija iespējama.

\subsubsection{Miopiskās novirzes salīdzinājums vienpusējai un abpusējai iedzimtai kataraktai}

Miopiskās novirzes lielums acīm ar vienpusēju un abpusēju iedzimtu kataraktu pēc operācijas parādīts 3.17. attēlā. Tā kā, iedalot vienpusēju un abpusēju iedzimtu kataraktu grupās atbilstoši bērna vecumam ķirurǵiskās korekcijas laikā, vienpusējas kataraktas gadījumu vairākās grupās bija l̦oti maz un miopisko noviržu dispersija tajās bija minimāla, salīdzinājām operēto vienpusējas un abpusējas IK acu miopiskās novirzes agrīnā operācijas vecumā - no bērna viena līdz sešiem mēnešiem - un bērniem, kam IK ķirurǵiskā korekcija veikta vēlākā vecumā (3.17.att.).

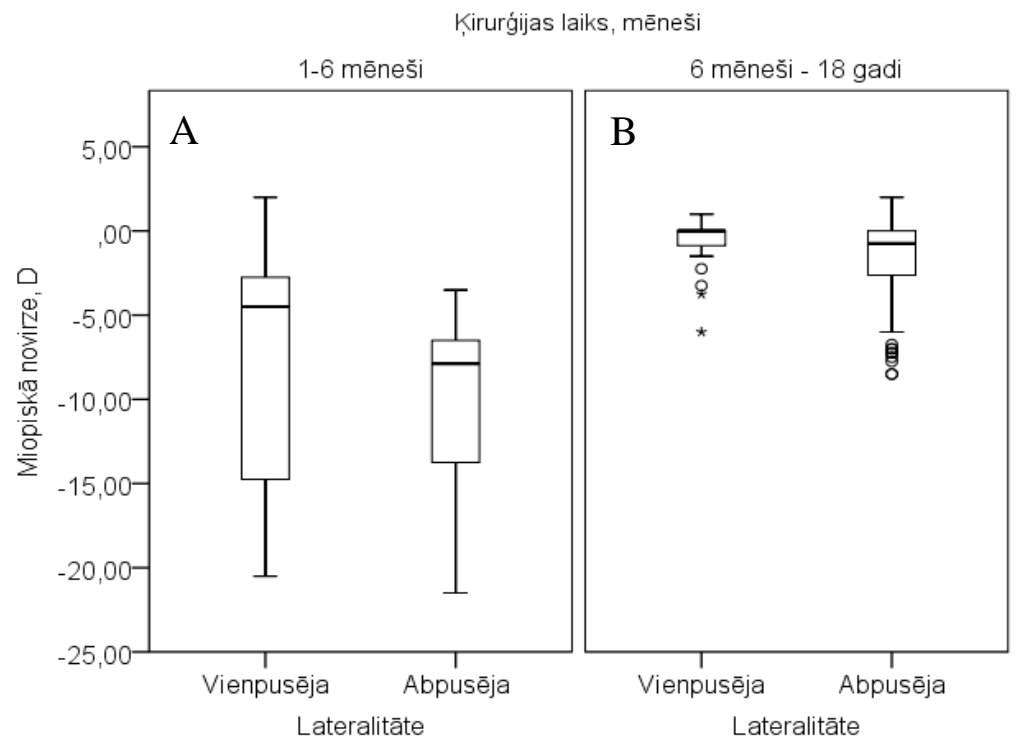

\subsection{7. att. Miopiskās novirzes lieluma salīdzinājums vienpusējai un abpusējai iedzimtai kataraktai dažādā vecumā operētiem bērniem: \\ A - agrīnā vecumā (1-6 mēneši); B - vecumā no sešiem mēnešiem līdz 18 gadiem}

Atšķirība, kas izveidojusies starp miopisko novirzi vienpusējas un abpusējas operētas iedzimtas kataraktas acīm dažādās IK ķirurǵiskas korekcijas vecuma grupās, nav statistiski nozīmīga ( $\mathrm{p}>0,05)$. Agrīnā vecuma primāras operācijas grupā (vecumā no viena līdz sešiem mēnešiem) abpusējas IK gadījumā mediāna ir 1,7 reizes lielāka nekā vienpusējas IK gadījumos, tomēr atšksirība nebija statistiski ticama. 


\subsection{Acs ar pseidofakiju refrakcijas izmaiṇu jeb miopiskās novirzes lielumu salīdzinājums, izmantojot dažādas IOL implantācijas mērķa refrakcijas taktikas}

Analizējot operētas IK acis, kur IOL implantācijā izmantotas divas atšķirīgas IOL implantācijas taktikas (emetropu un hipermetropu IOL implantācijas mērķa refrakcijas) kataraktas sākšanās laika grupās, maksimālajā novērošanas laikā netika novērota statistiski ticama ( $\mathrm{p}>0,05) \mathrm{MN}$ lieluma atšksirība (3.18. att.).

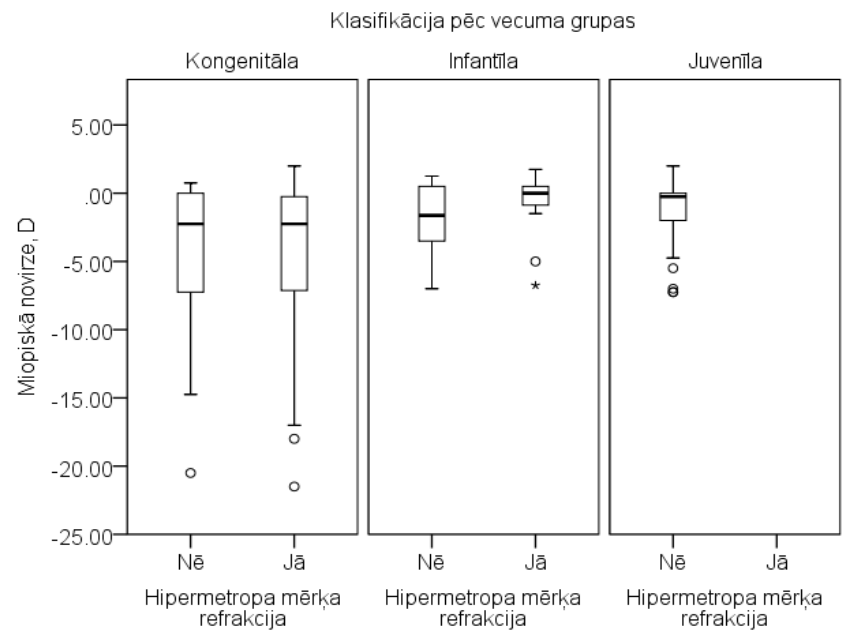

\subsection{8. att. MN salīdzinājums emetropu un hipermetropu IOL mērķa refrakcijas acīs ar pseidofakiju kataraktas sākšanās laika klasifikācijas grupās}

Salīdzinot miopiskās novirzes kongenitālo un infantilo dažādu IOL implantācijas taktiku grupās histogrammu veidā, ieguvām šādus attēlus un salīdzinājumu (3.19. A un B att.).
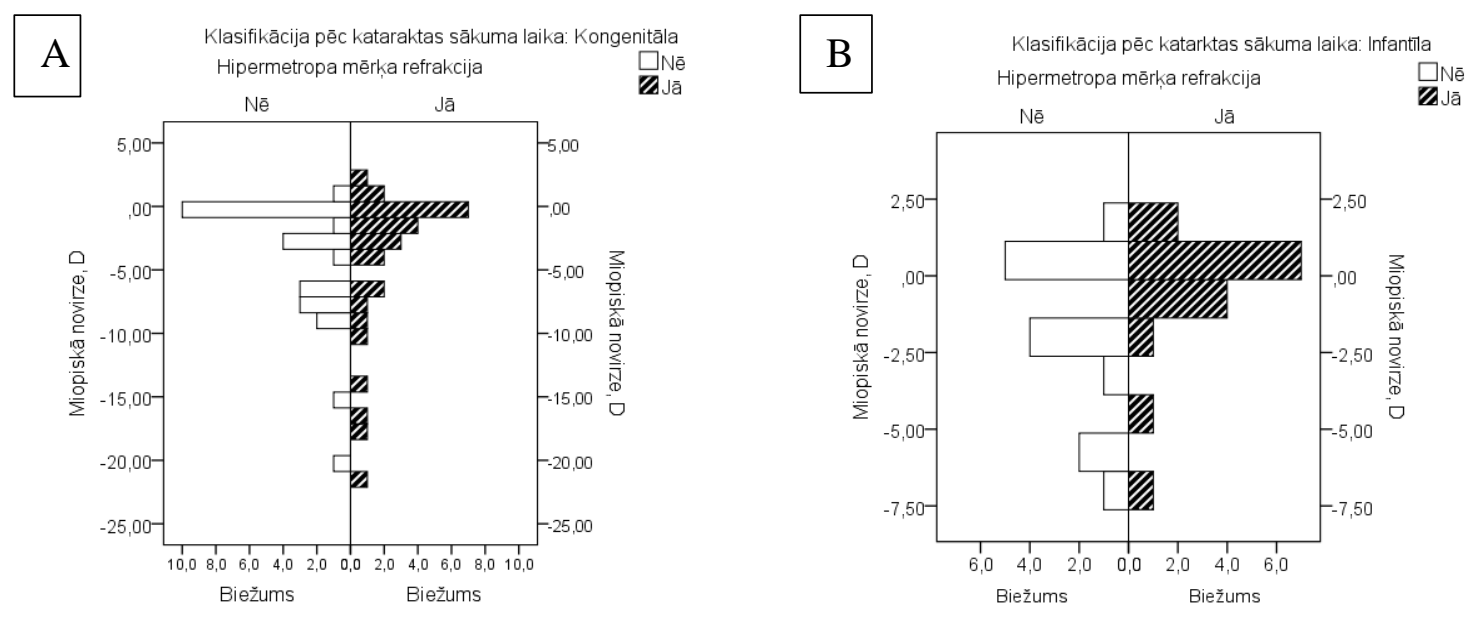

3.19. A un B att. Miopiskās novirzes lieluma histogrammu salīdzinājums

A - kongenitālai kataraktai,

B - infantilai iedzimtai kataraktai, kas ārstēta ar divām atšķirīgām IOL implantācijas taktikām 
Divu kongenitālās IK ārstěšanas taktiku (emetropas un hipermetropas IOL mērķa refrakcijas) grupās miopiskā novirze maksimālajā novērošanas periodā statistiski ticami neatšķīrās (Manna-Vitnija tests, $p=0,64$ ), tāpat atšķirība netika konstatēta arī infantilās IK grupā (Manna-Vitnija tests, $\mathrm{p}=0,25$ ).

\subsection{Miopiskās novirzes korelācija ar individuālo intraokulāro lēcu stiprumu acīm ar iedzimtu kataraktu un pseidofakiju}

Salīdzinot miopiskās novirzes lielumu un acs individuālo IOL stiprumu dažādos vecumos operētām acīm ar pseidofakiju, tika novērotas statistiski nozīmīgas sakarības (3.20. att.).

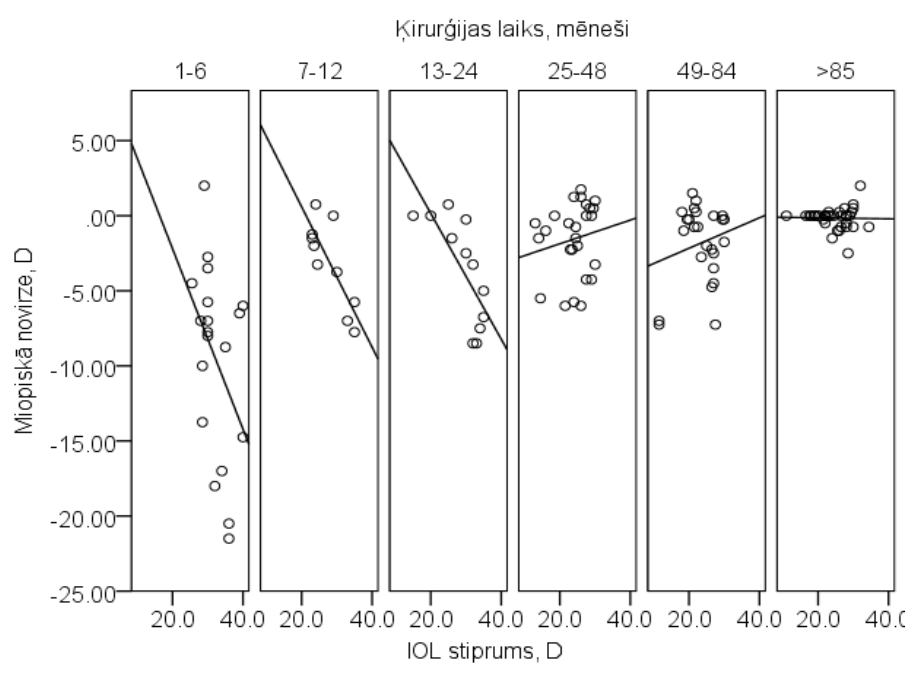

\subsection{0. att. Miopiskās novirzes lieluma un individuālā intra okulārās lēcas stipruma salīdzinājums dažādā bērna vecumā operētās pseidofakiskās acīs}

Acu ar pseidofakiju grupā, kurā operācija veikta bērniem no viena līdz sešu mēnešu vecumam, konstatē negatīvu, vidēju korelāciju starp $\mathrm{MN}$ un intraokulārās lēcas stiprumu ( $r s=-0,38)$, tomēr to var uzskatīt tikai par tendenci, jo tai nav statistiskas ticamības $(p=0,10)$. Lineārās regresijas analīzē konstatēja, ka, IOL stiprumam palielinoties par $1 \mathrm{D}$, miopiskā novirze palielinās vidēji par $0,61 \mathrm{D}(\mathrm{p}=0,01)$. Grupā, kurā IK operēta bērniem no septiniem līdz 12 mēnešiem, konstatē negatīvu, ciešu un statistiski ticamu korelāciju starp MN un IOL stiprumu (rs $=-0,74 ; p=0,01)$. Lineārās regresijas analīzē konstatēja, ka, IOL stiprumam palielinoties par $1 \mathrm{D}, \mathrm{MN}$ palielinās vidēji par $0,46 \mathrm{D}(\mathrm{p}=0,01)$. Grupā, kur operatīva terapija bijusi bērniem no 13 līdz 24 mēnešiem, konstatē negatīvu, ciešu un statistiski ticamu korelāciju starp MN un IOL 
stiprumu ( $\mathrm{rs}=-0,82 ; \mathrm{p}=0,001)$. Lineārās regresijas analīzē konstatēja, ka, IOL stiprumam palielinoties par $1 \mathrm{D}$, MN palielinās vidēji par 0,41 D $(\mathrm{p}<0,001)$. Negatīva korelācija starp miopisko novirzi un IOL stiprumu izpaužas acīm, kas operētas līdz 24 mēnešu vecumam, bet acīm, kas operētas pēc 24 mēnešu vecuma, nav novērojama statistiski ticama korelācija starp šiem rādītājiem $(p>0,05)$.

\subsection{Miopiskās novirzes salīdzinājums acīm ar iedzimtu kataraktu un pseidofakiju ar dažādām pēcoperācijas komplikācijām - sekundāru glaukomu un sekundāru kataraktu}

Analizējot iedzimtas kataraktas primārās ķirurǵiskās korekcijas komplikācijas/sekas, salīdzinājām pētījumā iekḷauto pacientu acu miopiskās novirzes maksimālajā novērošanas laikā acīm ar sekundāru glaukomu un bez tās un acīm ar sekundāru kataraktu un bez tās ātrajā postnatālajā acs augšanas fāzē un pārējā laikā (3.21. A un B att.).
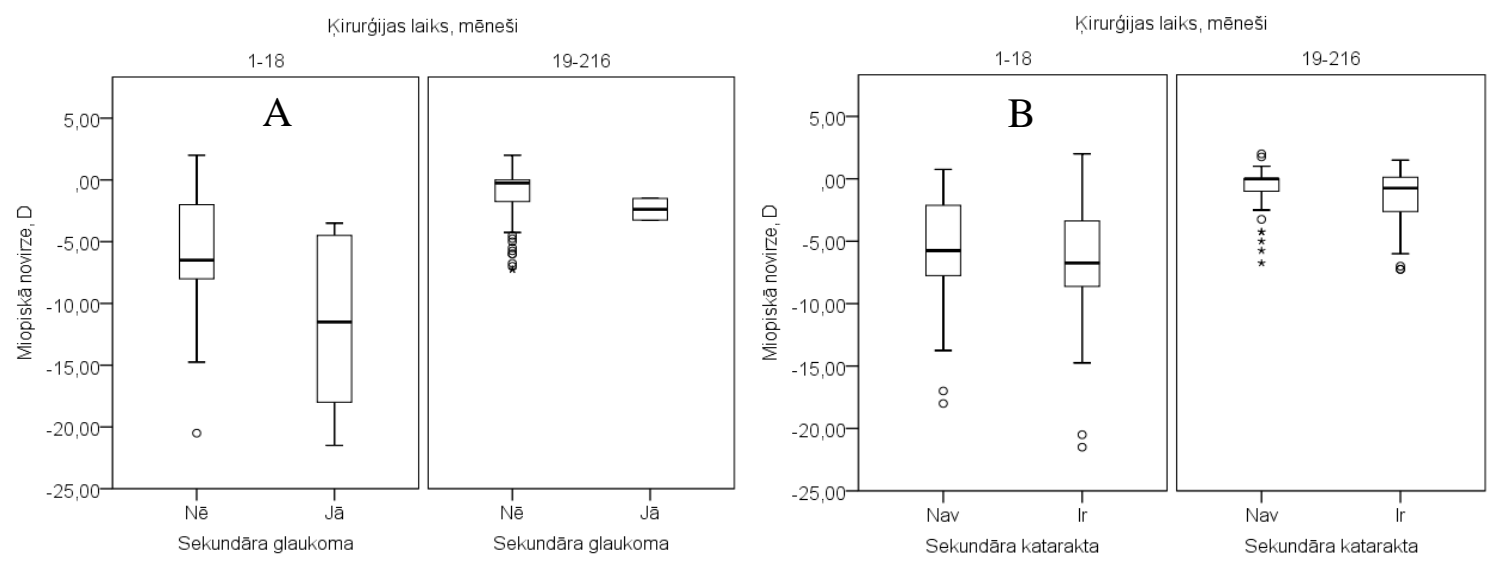

3.21. A un B att. Miopiskās novirzes salīdzinājums operētām iedzimtas kataraktas acīm

A - miopiskā novirze acīm ar sekundāru glaukomu un bez tās agrīnā postnatālā acs augšanas periodā (1-18 mēneši) un citā laikā (19-216 mēneši);

B - miopiskā novirze acīm ar sekundāru kataraktu un bez tās agrīnā postnatālā acs augšanas periodā (1-18 mēneši) un citā laikā (19-216 mēneši)

Agrīnā postnatālā acs augšanas periodā primāri operētām IK acīm ar sekundāru glaukomu un bez tās tika atrasta statistiski ticama miopiskās novirzes mediānu atšķirība (Manna-Vitnija tests, p=0,01) sk. 3.21. A attēlu. Pārbaudot dispersiju atšksirību acīm ar sekundāru glaukomu un bez tās agrīnā postnatālajā acs augšanas periodā, tika atrasta statistiski ticama atškirīība (Lēvena tests, $\mathrm{p}=0,02)$. Sekundāras glaukomas pacientiem dispersijas jeb izkliedes ir lielākas nekā pacientiem bez sekundāras glaukomas (3.21. A att.). 
Agrīnā postnatālā acs augšanas periodā primāri operētām IK acīm ar sekundāru kataraktu un bez tās netika atrasta statistiski ticama miopiskās novirzes mediānu atšķirība (Manna-Vitnija tests, $\mathrm{p}=0,70)$. Pārbaudot dispersiju atšķirību agrīnajā augšanas periodā operētām acīm ar sekundāru kataraktu un bez tās, netika atrastas statistiski nozīmīgas atšksirības (Lēvena tests, $\mathrm{p}=0,45)$.

\subsection{Kuirurğiski ārstētas redzei nozīmīgas iedzimtas kataraktas acs miopiskās novirzes lieluma ietekme uz bērna redzes attīstību}

Iedzimtas kataraktas ārstēšanas galvenais mērķis ir bērna redzes attīstība. Iedalot miopiskās novirzes lielumu trīs grupās un salīdzinot maksimālā iegūtā redzes novērtējuma lielumu katrā no šìm grupām, tika iegūti rezultāti, kas atspoguḷoti 3.22. attēlā un 3.1. tabulā.

Iegūtie rezultāti parāda - ja acs miopiskā novirze pēc iedzimtas kataraktas korekcijas ir līdz $-4,0$ D, tad 55\% acs redze novērtēta kā laba, 17\% kā vidēja, bet 28\% kā zema. Ja acs miopiskās novirzes lielums būs no $-4,0$ D līdz $-8,0$ D, labu redzi sasniegs tikai $25 \%$ acu. Ja acs miopiskā novirze pārsniegs $-8,0 \mathrm{D}$, nevienai no pētījumā ietvertajām acīm nevar redzi novērtēt kā labu.

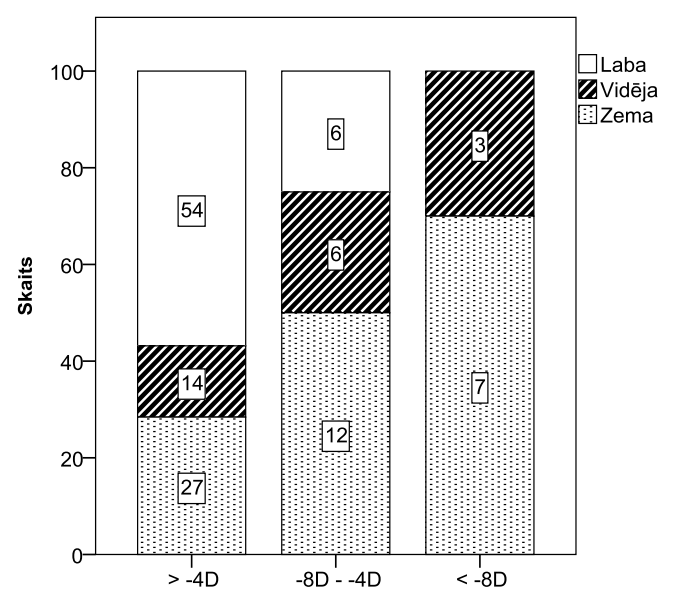

3.22. att. Operētas iedzimtas kataraktas acs refrakcijas miopiskās novirzes saistība ar acs redzes novērtējumu

3.1. tabula

Operētas iedzimtas kataraktas acs miopiskās novirzes ietekme uz acs redzes attīstību un redzes novērtējumu maksimālajā novērošanas laikā

\begin{tabular}{|c|c|c|c|}
\hline Miopiskā novirze & Zema redze & Vidēja redze & Laba redze \\
\hline$>-4,0 \mathrm{D}$ & $28 \%$ & $17 \% \%$ & $55 \%$ \\
\hline No $-4,0 \mathrm{D} \operatorname{li} \mathrm{dz}-8,0 \mathrm{D}$ & $50 \%$ & $25 \%$ & $25 \%$ \\
\hline$<-8,0 \mathrm{D}$ & $70 \%$ & $30 \%$ & \\
\hline
\end{tabular}




\section{DISKUSIJA}

Mūsu pētījuma mērķis bija izpētīt iedzimtu kataraktu kā unikālu, vienotu, heterogēnu nozoloǵisku vienību, apkopot un uzskatāmi parādīt iedzimtas kataraktas iedalījumus un to savstarpējās ietekmes.

Tā kā katarakta ir acs lēcas apdulı̧̧̧⿻jams un acs lēca ir viena no acs optiskās sistēmas sastāvdaḷām, tā vienmēr - gan ārstēta, gan neārstēta - ietekmēs acs refrakcijas kḷūdu un radīs refrakcijas kḷūdas izmaiņas. Katarakta zīdaiņa un maza bērna vecumā atšķiras no kataraktas pieaugušam cilvēkam un bērnam pēc septiņu gadu vecuma, jo kataraktas kā stāvokḷa vai slimības iedarbība un attīstība notiek vienlaikus ar redzes sistēmas attīstību [56].

Pētījums analizē operatīvi ārstētas iedzimtas kataraktas izraisītas acs refrakcijas izmaiṇas pēc kataraktas ekstrakcijas un intraokulāras lēcas implantācijas operācijas, bērnam augot un reizē acs ābolam augot. Darba apgrūtinājums un ieguvums reizē ir mūsu vēlme ņemt vērā visus faktorus, kas raksturo iedzimtu kataraktu un tās ārstēšanu, visus faktorus, ar ko jārēķinās ikdienas klīniskajā darbā, ārstējot zīdaini un bērnu ar iedzimtu kataraktu.

Mēs analizējām, kā acs refrakcijas kḷūdas izmaiņas pēc iedzimtas kataraktas ķirurğiskas korekcijas ar IOL implantāciju ietekmē IK dažādie veidi, bērna vecums un acs aksiālais garums primārās ķirurğiskās korekcijas laikā, dažādas ārstēšanas taktikas, individuālais intraokulāras lēcas stiprums un biežākās pēcoperācijas komplikācijas.

Iedzimtas kataraktas heterogenitāti parāda dažādie IK klasifikācijas veidi . Katra atsevišksa iedzimta katarakta var sākties dažādos laikos, ko atspoguḷo kataraktas sākšanās laika klasifikācija, vienlaikus tai var būt dažādi morfologiskie tipi, kā arī tā var būt izveidojusies tikai vienā acī vai abās bērna acīs. Reizē kā materiāla raksturojumu, bet arī kā rezultātu to esam attēlojuši 2.1. tabulā. Dažādie iedzimtas kataraktas veidi iekḷaujas viens otrā un papildina viens otru.

Iedzimta katarakta var sākties dažādos bērna vecumos. Pēc kataraktas sākšanās laika iedzimtu kataraktu klasificē kā kongenitālu - apduļ̧̧̧ojams izveidojies intrauterīni un ir redzams uzreiz pēc dzimšanas, kā infantilu - acs lēcas apduļ̧̧̧ojams izveidojas un tiek diagnosticēts pirmo divu gadu laikā - un kā juvenilu - apduļ̧̣⿻jams acs lēcā veidojas pēc bērna divu gadu vecuma. Šādu klasifikāciju varam atrast Wilson un kolēǵu grāmatā “Pediatric Cataract Surgery” [126]. Mūsu pētījuma izlasē pēc kataraktas sākšanās laika klasifikācijas izveidojās trīs savstarpēji salīdzināmas līdzịga apjoma grupas (sk. 2.1. tabulu). Klīniskajā praksē vairāku iemeslu dēḷ šo 
klasifikāciju bieži var apšaubīt, tomēr tā palīdz grupēt iedzimtu kataraktu, domāt par IK sākšanās laiku un analizēt iespējamās anamnēzes kḷūdas. Atklājot kataraktu ne uzreiz pēc dzimšanas, bet vecākā zīdaiņa vai bērna vecumā vienā vai abās acīs, ne vienmēr ir zināms un ticams, ka acs lēca iepriekš bijusi caurspīdīga. Pārliecināti par to varam runāt tikai, ja acs lēca iepriekš ir fotografēta, kā redzams literatūras apskata 1.7. attēlā. Jo precīzāka un sabalansētāka ir valsts veselības aizsardzības sistēma, aptverošāka redzes un acu skrīninga organizācija un tā rezultātu dokumentācija, jo precīzāk var noteikt iedzimtas kataraktas sākšanās laiku. Literatūras apskata 1.6.1. nodaḷā esam iztirzājuši "sārtā refleksa" testa nozīmību, kā arī aprakstījuši mūsu pētījumu par "sārtā refleksa" testa veikšanu un iegūtajiem rezultātiem Latvijā 2013. gadā [119].

Latviešu valodā arī nav vienkārši definēt iedzimtas kataraktas nosaukumu. Vai katarakta, kas klīniski tiek diagnosticēta bērnam piedzimstot, kuras etioloǵijā pierādīta intrauterīna masalu infekcija, tiks nosaukta par iedzimtu vai iegūtu intrauterīnā periodā? Pētījumā š̄ katarakta klasificēta kā iedzimta. Tomēr diskusijā gribam atzīmēt, ka precīzāk to būtu nosaukt par iegūtu kongenitālu kataraktu. Katarakta, kuras etiologijā būs pierādīta PAX6 gēna mutācija un kura klīniski diagnosticēta uzreiz pēc dzimšanas, klasificēta kā iedzimta kongenitāla. Acs lēca, kas trīs mēnešu vecumā fotodokumentācijā parādīta kā caurspīdīga (skat. literatūras apskata 1.7. attēlu), bet 12 mēnešu vecumā būs redzama kā puscaurspīdīgs lēcas kodola apdulj̧̧ojums, dokumentāli parādīs infantilu kataraktu. Ja tās etiologijā būs pierādīta noteikta gēna mutācija, to vajadzētu nosaukt par iedzimtu infantilu, bet šādu kataraktu būtu jāuzskata par iegūtu infantilu, ja tās etioloǵija būs saistîta ar acs traumu, medikamentu lietošanu vai saslimšanu. Katarakta, kas parādās bērnam 15 gadu vecumā ǵimenē, kurā visās paaudzēs kādam no pēcnācējiem novērojamas kataraktas, kas manifestējas vecumā no 10 līdz 20 gadiem, tiek saukta par iedzimtu juvenilu. Lasītājam, kas ikdienā nav saistīts ar iedzimtas kataraktas diagnostiku un ārstēšanu, iedzimtu kataraktu klasifikācija bieži var likties neizprotama. Latviešu valodā termins "iedzimts" bieži atspoguļos gan kataraktu, kas konstatēta uzreiz pēc dzimšanas, gan kataraktu, kura ir ǵenētiski pārmantojama un/vai ir saistīta ar noteikta gēna mutāciju.

Izbrīnu un pilnīgu neizpratni oftalmologos un sabiedrībā izraisīja sākotnēji pētījumā iekḷautas divu vienas ǵimenes bērnu iedomātas iedzimtas kataraktas, kuru etiolog̣ijā tika meklēta metabola pārmantota slimība, bet pārsteidzoši tika atklāts, ka kataraktu etioloǵija ir saistīta ar vardarbību pret bērnu. Pieminu šos gadījumus promocijas darba diskusijā, kā arī tie atspoguloti vienā no starptautiskajām publikācijām (sk. nodaļu "Promocijas darba aprobācija. Publikācijas").

Ja aplūkojam un analizējam acs lēcas apdulı̧̧ojamu dažādās bērna acs morfologiiskajās struktūrās, kataraktu varam klasificēt pēc lēcas morfologisiskās struktūras nosaukuma. Piemēram, 


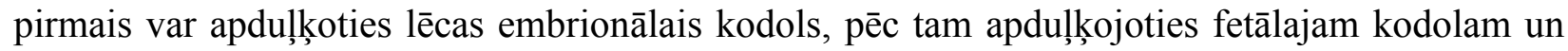
visai acs lēcai. Citā gadījumā acs lēcas kodols var saglabāties caurspīdīgs, kamēr tam apkārt esošā lēcas garoza apduļ̧̣ojas, veidojot dažādu veidu un rakstu kataraktu. Bieži ir sastopami apduļ̧̧̧ojumi mugurējā acs lēcas kapsulā vai tās tuvumā. Iedzimtas kataraktas morfologíiskie tipi dažādi ietekmēs pacientu ķirurğiskās ārstēšanas laiku, komplikāciju veidu un biežumu, operācijas tehnikas nianses, kā arī redzes prognozi, bērnam augot [31, 50, 70, 89, 90]. Mūsu pētījumā kataraktas morfologiskā uzbūve tika noteikta, izmantojot biomikroskopu vai rokas biomikroskopu un/vai operācijas mikroskopu. Randomizētajā multicentru prospektīvajā pêtījumā - “Z̄ìdaiņu afakijas ārstēšanas pētījumā” (IATS) - 83 iedzimtas kataraktas uzbūves video kataraktas ekstrakcijas laikā analizēja trīs iedzimtas kataraktas ārstēšanas eksperti, pēc tam vienojoties par kataraktas morfoloǵisko veidu, izmantojot apduļ̧̧̧ojuma intensitātes skalu lēcas slāņa un novietojuma raksturojumam [130]. Iedzimtas kataraktas klasificēšana pēc apduļ̧̣ojuma morfologiiskā novietojuma dod iespēju klasificēt kataraktu, noteikt tās ārstēšanas taktiku, laiku un iespējamo redzes prognozi [1,31]. Fenotipiska kataraktas heterogenitāte iedzimtas kataraktas gadījumos ir bieži sastopama. Vienā dzimtā var tikt novērotas dažādas kataraktas morfoloğiskās variācijas. Tas nebūs tik vienkārši, ka viena gēna mutācija noteiks viena veida fenotipiskas izmaiņas: cits gēns var modificēt izraisītājgēna ekspresiju. Morfoloǵiskās atšķirīibas var būt gan interokulāras (asimetriska katarakta bilaterālas kataraktas gadījumos), gan intrafamiliāras (dažāda veida un intensitātes katarakta vienas dzimtas pacientiem) [1, 71].

Pētot iedzimtas kataraktas morfoloǵisko uzbūvi, ieguvām šādus rezultātus. Latvijā agrīni - no bērna viena līdz sešiem mēnešiem - tika operēta tikai difūza/totāla un nukleāra katarakta, kuras neoperēšana iedzimtas kataraktas acij vai abpusējas kataraktas gadījumos arī bērnam var izraisīt aklumu. Palielinoties pacientu vecumam, totālas/difūzas operētas kataraktas skaits samazinājās, pieaugot citu iedzimtas kataraktas morfoloǵisko tipu operēto acu skaitam. Tas varētu būt saistīts ar kataraktas apduļ̧̧⿻juma progresiju līdz totālai/difūzai vai liecināt par novēlotu operāciju un kḷūdu kataraktas skrīningā (vai sārtā refleksa skrīningā). Mugurējā polārā katarakta mūsu izlasē tika operēta pēc 12 mēnešu vecuma. Vecumā no četriem līdz astoṇiem gadiem nebija operēta neviena difūza/totāla katarakta, bet vecumā pēc astoṇiem gadiem bija operēti visi sastopamie morfologiskie kataraktas tipi.

Iedzimta katarakta var būt vienā acī vai abās. Salīdzinot ārstēšanas rezultātus, redzes spējas acīs ar abpusēju vai vienpusēju kataraktu, bērniem ar vienpusēju kataraktu tika atzīmēta sliktāka redzes attīstība, bieži novērojot vidēju vai smagu vienas acs vājredzību. [14]. Vienpusējas un abpusējas kataraktas etioloǵija ir atšķirīga. Pārmantojamība (hereditary disease) 
tiek uzskatīta par iedzimtas kataraktas cēloni pusei no abpusējas iedzimtas kataraktas gadījumiem, kamēr vienpusējas kataraktas gadījumos tikai 10\% tiek saistîti ar pārmantojamību. 90\% vienpusējās kataraktas gadījumu tiek uzskatīti par sporādiskiem, kamēr abpusēja katarakta par sporādisku tiek uzskatīta tikai vienā trešdaļā gadījumu [105]. Acs lēcas apduļ̧̧̧šanās mehānisma izprašana nākotnē var būt atslēga idiopātiskas kongenitālas un infantilas iedzimtas kataraktas etioloǵijai [71]. Iedzimtas kataraktas dažādība liek raudzīties un analizēt katru IK gadījumu kā unikālu sistēmu. Mūsu darbā uzskatāmi to pierāda savstarpējā dažādo iedzimtas kataraktas veidu proporciju salīdzināšana, izmantojot $Z$ testu un parādot, ka dažādu klasifikāciju kataraktas grupās citas klasifikācijas veidu proporcijas statistiski ticami atšksiras.

Pētot izlasē ietilpstošo pseidofakisko acu pēcoperācijas komplikācijas - sekundāru glaukomu un sekundāru kataraktu -, iegūtos datus salīdzinot ar literatūras datiem, varam diskutēt par diagnostikas iespējām, komplikāciju atpazīšanu un iespējamām kḷūdām. Sekundāra glaukoma (SG) pēc pediatriskās kataraktas ķirurǵiskas korekcijas, pēc literatūras datiem, novērojama no 0\% līdz 32\% [17]. Mūsu pētījumā kongenitālas kataraktas grupā 13,5\% gadījumu agrīnā un/vai vēlīnā pēcoperācijas laikā pseidofakiskā acī attīstījās sekundāra glaukoma. Infantilas un juvenilas iedzimtas kataraktas grupās sekundāra glaukoma attīstìjās tikai 2,04\% gadījumu. Literatūras apskatā minētajos randomizētajos multicentru pētījumos - "Z̄̄daiņu afakijas ārstēšanas pētījumā" (IATS) un “IoLunder2" pētījumā - sekundāra glaukoma diagnosticēta biežāk. "Zìdainga afakijas ārstēšanas pētījumā" pierādīta glaukoma vai aizdomās par to IOL korekcijas grupā bija 28\% $(\mathrm{P}=.55)[63,105]$.

Biežākā pediatriskās kataraktas ķirurğiskas korekcijas komplikācija ar IOL implantāciju ir lēcas reproliferācija redzes ass rajonā [92]. "Zìdaiņa afakijas ārstēšanas pētījumā" 24 acīs no 57 (42\%), kurās bija implantētas IOL, attīstìjās lēcas reproliferācijas [94], [95]. Mūsu pētījumā mēs ieguvām l̦oti līdzīgus rezultātus, 58 (42,65\%) no 138 acīm ar pseidofakiju attīstījās lēcas reproliferācijas un/vai sekundāras kataraktas. Analizējot acs lēcas reproliferācijas un/vai sekundāras kataraktas biežumu, vienlaikus gribam pieminēt dažādos vecumos izmantotās atšķirīgās ķirurğiskās korekcijas tehnikas, kas arī pierāda iedzimtas kataraktas heterogenitāti un atšksirīgos bērna vecumos mainīgo acs lēcas un stiklveida ķermeņa morfoloǵisko uzbūvi.

Mūsu pētījuma mērķis bija ne tikai izprast redzei nozīmīgas iedzimtas kataraktas heterogenitāti un būtību, bet arī izpētīt pseidofakiskas acs refrakcijas izmaiņas un to ietekmējošos faktorus.

Aci, kurā tiek implantēta mākslīga intraokulāra lēca, sauc par pseidofakisku aci. Par iespējām korig̣èt afakiju ar intraokulāru korekciju arī bērnu vecumā tika domāts jau sen. 
Dr. Edward Epstein un prof. D. Peter Choyce (Apvienotā Karaliste) veica pirmo IOL implantāciju bērniem 20. gadsimta 50. gadu beigās [131]. Citā literatūras avotā atzīmēts, ka pirmā intraokulāro lēcu implantācija bērniem dokumentēta 1951. gadā, kā autori atzīmēti Letocha un Pawlin [67]. 21. gadsimta sākumā IOL implantācija ar labiem rezultātiem tiek veikta bērniem, vecākiem par diviem gadiem. Lielā daḷā pasaules valstu bērnu kataraktas ķirurgi to veic rutīnā [126]. Divi salīdzinoši nesen publicēti pētījumi ir snieguši pierādījumus par IOL implantācijas efektivitāti un drošumu ar̄̄ jaunākiem bērniem [95, 105]. Uzlabojoties IOL materiāliem un dizainam, uzlabojoties kataraktas operācijās lietotajām tehnologijāām un ķirurǵijas tehnikai, IOL implantācija ir akceptēta un droša daudzos gadījumos daudz jaunākiem pacientiem, kā minēts vienā no jaunākajām grāmatām par iedzimtu kataraktu - "Congenital Cataract. A Concise Guide to Diagnosis and Managment" [71, 109]. Implantējot acī mākslīgu intraokulāru lēcu ar noteiktu refrakciju, veidosies sākotnējā pseidofakiskas acs refrakcija, kas, bērnam un acij augot, mainīsies. 2002. gadā publicētajā Superstein un kolēgu pētījumā acu ar pseidofakiju miopiskā novirze ir 1,5 D salīdzinājumā ar pacientiem ar afakiju, kuru miopiskā novirze bija 7,8 D. Pētījuma secinājumos autori raksta, ka laba stratēgéija intraokulāro lēcu aprēķiniem pacientiem ar pseidofakiju būtu sākotnēja pēcoperācijas emetropija.

Tomēr jau sākotnēji, balstoties uz novērojumiem par acs augšanu un refrakcijas izmain̄ām zīdaiņa un bērna vecumā [37], kā arī uz iedzimtas kataraktas ārstēšanas pieredzi acīm ar afakiju [79], pseidofakijas gadījumos pamatota hipermetropa IOL mērķa refrakcija.

Lielākās izmaiņas acs augšanā un miopizācijā notiek tieši bērna pirmajos gados un pirmajos mēnešos. Jo plašāku un atšķirīgāku bērna vecumu primāras ķirurǵiskas korekcijas laikā iekļaus pētījuma grupā, jo neprecīzāki un nelietderīgāki būs pētījuma rezultāti. Tāpēc, lai korekti analizētu acs refrakcijas izmaiņu ietekmējošos faktorus, mēs savā pētîjumā tieši jaunākajam bērnu vecumam - bērniem līdz diviem gadiem - izveidojām trīs atsevišķas grupas bērnu vecumiem, kad veikta kataraktas ekstrakcija un IOL implantācija: no viena līdz sešiem mēnešiem, no septiņiem līdz 12 mēnešiem un no 13 līdz 24 mēnešiem. Dalīšana šādās mazās grupās ietekmē statistisko analīzi, samazinot izlases lielumu un pētījuma stiprumu, taču tas dod iespēju salīdzināt līdzīgā vecumā operētas acis, kuru lielums, augšanas spējas, refrakcijas izmaiņas operācijas laikā un pēc operācijas būs līdzīgi (sk. 2.2. tabulu, 3.8. A attēlu). Papildus kopējo izlasi sadalījām grupās, kas vienlaikus atspoguḷo laiku, kad izdarīta primārā ārstēšana, un acs augšanas periodus (sk. 2.3. attēlu un 3.8. B attēlu).

Mūsu pêtījumā bija 41 iedzimtas kataraktas pacientu acs, kas bija operēta no viena līdz 24 mēnešu vecumā. Tā bija daļa no mūsu pētījuma kopējās izlases, kurā kopā bija 138 acis 
85 pacientiem, kas tika operēti no viena mēneša līdz 18 gadiem. Promocijas darba literatūras apskatā publicētajā VanderVeen apkopotajā tabulā [121] (sk. 1.4. tabulu) uzskaitīti 11 pētījumi, kuros miopiskā novirze pētìta agrīnā vecumā operētu iedzimtas kataraktas pacientu izlasēs. Aplūkojot izlašu lielumus un bērnu vecumus tajos, redzams, ka bieži sākotnēji autori izvēlējušies pêtīt visus bērnu vecuma kataraktas gadījumus, kamēr tālāk izlases samazinātas, izveidojot apakškopas pacientiem līdz sešu mēnešu vecumam, vienam vai diviem gadiem [121]. Attiecībā uz miopiskās novirzes lielumu pētījumos sniegtie rezultāti ir līdzīgi mūsu pētījuma rezultātiem, sevišksi, ja tiek ievēroti līdzīgi analizējamās grupas parametri - bērnu vecums operācijas laikā un novērošanas ilgums.

Visu šo pētījumu rezultāti apliecina, ka zīdaiņiem ar iedzimtu kataraktu pēc lensektomijas un intraokulārās lēcas implantācijas operācijas laikā līdz divu gadu vecumam attīstīsies miopiskas refrakcijas izmainas vismaz no -4 dioptrijām līdz pat -10 dioptrijām. Mūsu pētījums, tieši tāpat kā McClatchey [79], Lambert [57] un “Zīdaiṇu afakijas ārstēšanas pētījums” (IATS) [58], demonstrē, ka, jo agrīnāk tiek veikta IOL implantācija, jo lielāka miopiskā novirze attīstīsies. Tas ir jāṇem vērā operācijas laika un afakijas ārstēšanas korekcijas izvēlē. Ir jāapsver visi ieguvumi un trūkumi izteiktas miopiskās novirzes attīstības gadījumos [58, 70, 105].

Papildus kopējo izlasi sadalījām grupās, kas vienlaikus atspoguḷo laiku, kad izdarīta primārā ārstēšana un acs augšanas periodus (sk. 3.8. b attēlu). Ātrajā acs augšanas periodā (1-18 mēneši) [37] miopiskās novirzes mediānas lielums un dispersija ir statistiski ticami lielāka nekā abos lēnajos acs augšanas periodos un periodā, kad acs vairs neaug (Lēvena tests, p < 0,05). Mūsu pētījumā tika atrasta statistiski ticama korelācija starp acs aksiālo garumu primārās ķirurğiskās korekcijas laikā un pseidofakiskas acs refrakcijas izmaiṇu miopiskā virzienā miopiskās novirzes lielumu maksimālā novērošanas periodā ( $\mathrm{rs}=0,3 ; \mathrm{p}=0,01$, skat 3.10. attēlu).

Izvērtējot miopisko refrakcijas izmaiņu standartnovirzes un dispersijas, iedzimtas kataraktas acīm ar dažādu acs garumu kataraktas ekstrakcijas un intraokulāras lēcas implantācijas laikā, mēs ieguvām statistiski pamatotu acs aksiālā garuma robežlielumu - 19 mm, līdz kura sasniegšanai operētajās iedzimtas kataraktas acīs, bērna acij augot, tiek novērota liela, neparedzama un izkliedēta (dispersa) acs refrakcijas miopiskā novirze. Tas var tieši un precīzi palīdzēt klīnicistiem, kas strādā ar iedzimtas kataraktas pacientiem, izšķirities, kurās acīs implantēt intraokulāru lēcu un kuras atstāt afakiskas, refrakcijas kḷūdu koriǵējot ar kontaktkorekcijas metodi. Acīm ar $\mathrm{AG}<19 \mathrm{~mm}$ un acīm ar AG $\geq 19 \mathrm{~mm}$ statistiski ticami un izteikti atšķīrās gan MN mediānu lielums, gan dispersijas (sk. 3.11. A un B un 3.12. attēlu). 
Mūsu pētījumā iegūto acs garuma robežlielumu apstiprina un pamato arī zīdaiņu afakijas pētījumā (Infant Aphakia Treatment study) iegūtie dati, kurā pētnieki kā klīniski nozīmīgu paredzamās kḷūdas ietekmējošo faktoru min acs aksiālo garumu primārās ķirurǵiskās korekcijas laikā [122]. Pētījumā saistībā ar acs aksiālo garumu ķirurǵiskas korekcijas laikā tika veidotas divas grupas, pirmajā grupā bija acis $<18 \mathrm{~mm}$, otrajā $>18 \mathrm{~mm}$. Acīm, kuru aksiālais garums ķirurgiskas korekcijas laikā bija < 18 mm (27 acis), vidējā paredzamā kḷūda bija 1,8 (2,0)D, kamēr acīm $>18$ mm (22 acis) tā bija $-0,1(1,6)$ D, p,0,01 [122].

IOL aprēķinu formulu salīdzinošo neprecizitāti veicina acs aksiālā garuma mērīšanas grūtības zīdaiņa un maza bērna vecumā, kā arī kontakta $A$ scan metodes un IOL aprēķinu formulu salīdzinošā neprecizitāte. Kaut arī veikti vairāki pētījumi IOL aprēķināšanas formulu precizitātes izvērtējumam bērniem, tomēr paredzamā kḷūda mazām acīm joprojām paliek augstāka nekā pieaugušajiem [2, 117].

Ja tiek pētītas iedzimtas kataraktas acis, kuru garums primārās ķirurǵiskās korekcijas laikā ir salīdzinoši lielāks, acs aksiālā garuma ietekmi uz miopiskās novirzes attīstības lielumu un IOL mērḳa refrakcijas paredzamo kḷūdu var arī neatrast. Piemēram, Peru pētnieku grupa 2018. gadā publicētajā rakstā neatrod sakarību starp iniciālo acs aksiālo garumu operācijas laikā un miopiskās novirzes attīstību trīs gadus pēc operācijas [120]. Viṇu pêtījumā iedzimtas kataraktas acis primārās ķirurǵiskās korekcijas laikā tika iedalītas divās grupās: ar acs aksiālo garumu $<21,5 \mathrm{~mm}$ un acs aksiālo garumu > 21,5 mm. Analizējot acābola garuma grupas, varam secināt, ka pirmajā grupā $(\mathrm{AG}<21,5 \mathrm{~mm})$ ietilps visas iedzimtas kataraktas, kas operētas ātrajā postnatālajā un lēnajā infantilajā fāzēe, un tajā ietilps bērni no viena mēneša līdz piecu gadu vecumam [37, 65]. Varam oponēt pētījuma autoru secinājumiem, minot, ka pētījumā salīdzinātajās pacientu grupās iekļautas iedzimtas kataraktas acis ar l̦oti dažādiem un atšksirīgiem raksturojošiem lielumiem - dažādu bērnu vecumu un acs aksiālo garumu kataraktas ekstrakcijas laikā.

Mēs savā pētījumā nesalīdzinājām, bet būtu interesanti salīdzināt acs ābola garuma izmaiṇu lielumu dažāda veida iedzimtas kataraktas grupām pēc kataraktas ekstrakcijas, bērnam augot. Salīdzinot acs aksiālā garuma izmaiņas, Lambert un citi pētījumā "Infant Aphakia Treatment study" piemin, ka acis ar vienpusēju iedzimtu kataraktu ir īsākas nekā otra veselā acs. Aksiālā garuma izmaiņas acīs ar kontaktkorekciju bija mazākas nekā acīs ar intraokulāru korekciju [62]. Lorenz un citi 1993. gadā savā pētījumā "Ocular growth in infant aphakia. Bilateral versus unilateral congenital cataracts" atzīmē sliktu korelāciju starp acābola garuma un acs refrakcijas izmain̄ām bilaterālas iedzimtas kataraktas gadījumos. Līdz ar to atzīmējot kā 
trūkumu refrakcijas izmaiņu neparedzamību un neiesakot koriğēt iedzimtas kataraktas acis pēc kataraktas ekstrakcijas ar intraokulāru korekciju [72].

Šodien, 25 gadus pēc šī un citu pētnieku izteiktajiem secinājumiem, arvien biežāk līdzīga veida argumenti tiek pārskatīti. Arī afakijas un kontaktkorekcijas gadījumos tiek novēroti vismaz divu veidu pamatoti trūkumi. Ja kontaktlēca tiek pazaudēta vai aprūpētāji pārstāj lietot kontaktkorekciju, zīdaiņa afakiskas acs refrakcijas kḷūda ilgstoši var palikt nekorig̣èta, kas izteikti palielina ambliopijas attīstības risku. Kontaktlēcas ir dārgas, un kaut arī tās būtu medicīniski nepieciešamas (indicētas), ja valsts vai apdrošināšana tās neapmaksā vai valsts veselības sistēma nenodrošina zīdaiņa savlaicīgu un pastāvīgu novērošanu pēcoperācijas periodā, refrakcijas kḷūdas korekcija var nenotikt. Papildus afakijas trūkumos jāiekḷauj iespējamās radzenes čūlas, kas var veidoties ilgtermiņa kontaktlēcu nēsāšanas gadījumos [109].

Salīdzinot refrakcijas izmaiṇu miopiskās novirzes lielumu piecām galvenajām iedzimtas kataraktas morfologiskajām grupām, statistiski nozīmīgi lielāka miopiskā novirze tika novērota difūzas/totālas un nukleāras kataraktas grupās (skat. 3.13. B att.). Lai nošķirtu kataraktas sākšanās laika ietekmi no morfoloǵiskās dažādības ietekmes, mēs atsevišksi analizējām morfologiski dažādās kataraktas grupas dažādos kataraktas sākuma periodos (skat. 3.14. un 3.16. A, B un C att.). Kā redzams rezultātos, Kraskela-Vollisa statistiskā testa analīzē totālas/difūzas un nukleāras IK morfologijijas gadījumā miopiskā novirze dažādās kataraktas sākšanās laika grupās kongenitālā, infantilā un juvenilā - statistiski ticami atšksiras (p=0,01) (3.14. A, B, C attēls), kas pierāda kataraktas sākšanās laika ietekmi. McChatney agrīnajos afakiskas acs miopiskās novirzes pêtījumos atzīmēe, ka iedzimtas kataraktas morfologiskais tips un kataraktas sākšanās laiks ir atkarīgi viens no otra un ietekmē miopiskās novirzes lielumu. Tomēr viņš ziņo, ka kataraktu morfoloǵija, sekundāra glaukoma, dzimums, lateralitāte un labākais koriǵētais redzes asums tikai nedaudz maina miopiskās novirzes lielumu, kā galveno iemeslu minot un pierādot agrīnu kataraktas operācijas laiku [77].

Domājot par lateralitāti, mūsu rezultāti neparādīja statistiski nozīmīgu atšķirību miopiskās novirzes lielumā starp vienpusējas un abpusējas kataraktas grupām. Literatūrā miopiskās novirzes lielums iedzimtas vienpusējas un abpusējas kataraktas acīm pēc operācijas ir pētīts atkārtoti. Gouws atzīmē, ka sfēriskais ekvivalents 36 mēnešus pēc kataraktas operācijas bija nozīmīgi vairāk miopisks vienpusējas kataraktas gadījumos, salīdzinot ar abpusējas kataraktas grupu [38]. McClatchey [78] un Hoevenaars [46] nonākuši pie līdzīgiem secinājumiem. Lambert un kolēg̣i ziṇo, ka vienpusējas kataraktas operācija asociējas ar lielāku acs aksiālā garuma pagarināšanos nekā abpusējas kataraktas operācija [62]. 
Pētot ķirurğiski ārstētas iedzimtas kataraktas komplikāciju ietekmi uz acs refrakcijas izmaiṇu lielumu, jau 1994. gadā britu iedzimtas kataraktas pētnieku grupa raksta, ka sekundāra glaukoma palielina acs refrakcijas miopiskās novirzes lielumu [1]. Salīdzinot miopiskās novirzes lielumu pacientiem ar sekundāru glaukomu un bez tās mūsu pētījumā, miopiskās novirzes mediāna pacientiem, kam primārā kataraktas ekstrakcija un IOL implantācija veikta 1-6 mēnešu vecumā un kam pēc laika attīstījusies sekundāra glaukoma, bija -11,5 D, kamēr mediāna acīm, kam netika konstatēta sekundāra glaukoma, šajā pašā grupā bija -7,75 D. Tomēr mūsu pacientu skaits ar sekundāru glaukomu nav pietiekami liels, lai izdarītu statistiski ticamus secinājumus.

Lai arī sekundāra katarakta maina acs refrakcijas kḷūdu, pētījumos par acs miopisko novirzi sekundāra katarakta netika atzīmēta kā faktors, kas to ietekmē miopiskās novirzes lielumu. Arī mūsu pêtījumā ne agrīnā - àtrajā acs augšanas fāzē $(1$ - 18 mēn.) - operētām acīm, ne vēlākā laikā (19 - 216 mēn.) operētajām acīm ar sekundāru kataraktu un bez tās netika atrasta ne statistiski ticama miopiskās novirzes mediānu atšksirība (Manna-Vitnija tests, $\mathrm{p}=0,70$ ), ne statistiski ticama dispersiju atšķirība (Lēvena tests, $\mathrm{p}=0,45$ ).

Salīdzinot miopiskās novirzes lielumu dažādu ārstēšanas taktiku- emetropas un hipermetropas mērķa refrakcijas - grupās, sadalot tās sīkāk pēc vecuma, kurā veikta kataraktas ekstrakcija un IOL implantācija, tika novērots, ka miopiskās novirzes lielums statistiski nozīmīgi neatšķiras $(p>0,05)$ dažādu IOL mērḳa refrakciju grupām dažādos kataraktas ekstrakcijas un IOL implantācijas vecumos (skat. 3.18. un 3.19. att.). Š̄ pētījuma daļa ir unikāla, - nekur literatūrā mēs neatradām pseidofakiskas acs refrakcijas izmaiņu salīdzinājumu dažādām IOL mērķa refrakcijām. Tas liecina, ka mērķa refrakcija neietekmē miopiskās novirzes lielumu un pēc IOL implantācijas acs refrakcija main̄̄sies neatkarīgi no sākotnējās refrakcijas veida un lieluma. Dažādās mērķa refrakcijas taktikas daļēji var pielīdzināt afakijas korekcijai ar kontaktkorekciju vai intraokulāru lēcu. Zīdaiņu afakijas ārstēšanas pētījumā aprakstīts, ka kontaktlēcu grupā acs miopiskā novirze bija $-6,8 \mathrm{D}$, salīdzinoši ar $-9,66 \mathrm{D}$ lielu miopisko novirzi IOL grupā [58]. Lielākā miopiskā novirze pseidofakiskās acīs tiek saistīta ar intraokulārās lēcas augsto optisko stiprumu. Lambert un kolēǵi “Z̄̄̄aiņu afakijas ārstēšanas pētījumā” izdarījuši secinājumu, ka izvēlētās IOL stiprums kopā ar acs aksiālā garuma pieaugumu un koriǵējošās lēcas lokalizāciju (kapsulu somā, uz radzenes vai brillıu stiklu attālumā) ietekmē miopiskās novirzes lielumu. Lielāks IOL stiprums izrais̄̄s lielāku miopisko novirzi uz vienu acs augšanas milimetru [58]. Taču nekur literatūrā mēs neatradām konkrētu korelācijas lieluma atšksirību dažāda agrīna zīdaiṇa vecuma grupām (no diviem līdz sešiem mēnešiem, no septiņiem līdz 24 mēnešiem) un robežu, 
kad korelācija starp miopiskās novirzes lielumu un intraokulārās lēcas stiprumu vairs netiks novērota.

Mūsu pētîjumā, salīdzinot miopisko novirzi un implantēto lēcu stiprumus acu grupām, operētām dažādos bērna vecumos, novērojām negatīvu korelāciju starp miopisko novirzi un IOL stiprumu acīm, kas operētas līdz bērna divu gadu vecumam (3.20. attēlu). Pēc operācijas agrīnā vecumā no viena līdz sešiem mēnešiem IOL stipruma pieaugums par $1 \mathrm{D}$ izraisīs lielāku MN pieaugumu nekā tad, ja operācija veikta vecumā no septiņiem līdz 24 mēnešiem. Vēlākā vecumā operētām acīm netika novērota intraokulārās lēcas stipruma un MN korelācija.

Lai novērotu un izprastu refrakcijas izmaiņas un bērna redzes attīstību, nepieciešams noteikts novērošanas laiks. Jo jaunāks būs pacients IK ķirurǵiskas korekcijas laikā, jo tas būs nozīmīgāk. Dažādie novērošanas ilgumi izskaidrojami ar dažādo IK pacientu vecumu ķirurğiskas korekcijas laikā, kas nosaka dažādu novērošanas ilgumu iespējas un nepieciešamību. Mūsu pêtījumā minimālais apsekošanas/novērošanas ilgums bija seši mēneši, maksimālais - 120 mēneši, vidējais novērošanas ilgums bija 47,8 (SD = 37,21) mēneši jeb 3,9 gadi. Randomizētajā multicentru pētījumā - "Zīiaiṇu afakijas ārstēšanas pētījums" (IATS) ASV acs refrakcijas izmaiņas, komplikācijas, reoperācijas un redzes attīstība tika salīdzinātas mēnesi pēc operācijas un bērna piecu gadu vecumā [58]. "IoLunder2” pētījumā asociāciju starp IOL implantāciju un redzes asumu, sekundāru glaukomu kā IK ārstēšanas komplikāciju analizēja gadu pēc kataraktas ķirurğiskas korekcijas un IOL implantācijas [105]. Pediatriskās kataraktas ķirurǵijas ekspertu Lloyd un Lambert 2017. gad̄̄ izdotajā grāmatā "Congenital Cataract: A Concise Guide to Diagnosis and Management" VanderVeen apkopotajā tabulā, kas adaptēta un publicēta promocijas darba literatūras apskatā (skat. 1.4. tab.), parādīti dažādu autoru pētījumu novērošanas periodi. Minimālais novērošanas ilgums Lambert un kolēǵu 1999. gadā publicētajā pētījumā [57] bija viens gads, maksimālais novērošanas ilgums 2000. gadā publicētajā McClatchey un kolēǵu pêtījumā [79] bija astoņi gadi.

Lai pārvarētu nevienādo novērošanas ilgumu izlases pacientiem mūsu pētîjumā, tika aprēķināta miopiskā novirze/gadā dažādās IK operācijas vecuma grupās. Pastāv vidēja pozitīva un statistiski ticama korelācija starp bērna vecuma grupām IK operācijas laikā un miopiskās novirzes lielumu gadā $(\mathrm{Rs}=0,062 ; \mathrm{p}=0,001)$. Jo mazāks ir bērna vecums operācijas laikā, jo lielāka būs miopiskā novirze gadā. Jo lielāks bērna vecums operācijas laikā, jo vairāk miopiskā novirze tuvojas nullei. Miopiskās novirzes izmaiṇas gadā saglabā to pašu tendenci, ko parāda MS lieluma izmaiņas izlases maksimālajā novērošanas periodā. 
Pētot redzes attīstību zīdaiņiem un bērniem ar pseidofakiju pēc iedzimtas kataraktas ķirurğiskas korekcijas, redzes attīstības novērtējumu maksimālā novērošanas laikā salīdzinājām ar acs refrakcijas miopisko izmaiņu lielumu. Redzes prognozi zīdaiņiem ar pseidofakiju ietekmē daudz faktoru: iedzimtas kataraktas sākšanās laiks, morfologiiskais IK tips, vecums, kad veikta IK primāra ķirurğiska korekcija [1, 70], afakiskas vai pseidofakiskas acs refrakcijas izmaiņas slimības, kas pievienojušās vai komplikācijas - šksielēšana, nistagmi, sekundāra glaukoma, sekundāra katarakta, kā arī ambliopijas attīstība un līdzestība ambliopijas ārstēšanā [71]. Pētot dzīvnieku modẹ̦us, ir zināms, ka agrīna redzes deprivācija izraisa acs aksiālā garuma palielināšanos un novirzi miopijas virzienā [88, 124]. Saskaņā ar to zīdaiņiem ar samazinātām redzes spējām varētu veidoties izteiktāka miopiskā novirze nekā zīdaiṇiem ar labāku redzi. Tomēr mūsu pētījumā un arī izpētîtajā literatūrā vispirms noteikti varam atzît, ka zīdaiņiem ar lielāku un straujāku miopiskās novirzes attīstību veidosies sliktākas redzes spējas. McClatchey raksta, ka labākais koriǵētais redzes asums tikai nedaudz ietekmē miopiskās novirzes lielumu [77]. Gouws atrada izteikti lielāku miopisko refrakcijas kḷūdu grupā ar vienpusēju kataraktu un zemāku redzes asumu salīdzinoši ar bilaterālas kataraktas grupu ar labāku redzes asumu un saredzēja šeit saistību starp sliktu redzes spēju un miopisko novirzi [38]. Arī Superstein ir līdzīgs ziņojums, kurā bērniem, kam kataraktas operācija notikusi līdz sešu mēnešu vecumam un kam pēcoperācijas redzes asums ir 20/40 un labāks, bija mazāka miopiskā novirze nekā bērniem ar sliktāku redzes asumu. Minētie izcilie rezultāti pēc tik agrīnas kataraktas operācijas gan salīdzinoši ar citiem pētījumiem un mūsu pieredzi izklausās diezgan mazticami, tomēr gribam minēt, ka Superstein atzīmē redzes asumu kā vienu no miopiskās novirzes attīstību ietekmējošiem faktoriem [108].

Diskusijas nobeigumā gribam vēlreiz atgriezties pie diviem nozīmīgākajiem pētījumiem pēdējos gados, kuros salīdzināta iedzimtas kataraktas afakijas korekcija ar kontaktkorekciju vai intraokulāru korekciju, izvērtēta iedzimtas kataraktas diagnostika, ārstēšana, komplikācijas un redzes prognoze. Pētījumu par iedzimtu kataraktu salīdzinoši nav daudz, tas vienmēr ir izaicinājums pētīt retu slimību zīdaiņu un bērnu vecumā, sevišķi mazā valstī, kāda ir arī Latvija. Nejaušinātā multicentru prospektīvā pētījumā "Zīiaiṇu afakijas ārstēšanas pētījumā” (Infant Aphakia Treatment Study (IATS)) tika izvērtēta labākā refraktīvā korekcija bērniem ar iedzimtu unilaterālu kataraktu, secinot, ka nevienai no šīm metodēm nav priekšrocību [49]. "Zīdaiņu afakijas ārstēšanas pētījums" un IOLu2 pētījums izgaismoja salīdzinoši lielo perioperatīvo un postoperatīvo komplikāciju skaitu zīdaiņiem, kam IOL implantācija veikta līdz sešu mēnešu vecumam [94, 105]. Salīdzinot iegūto redzes asumu 4,5 gadu vecumā vienpusējas kataraktas 
pacientiem, IATS neparādīja izteiktu atškşirību starp bērniem, kam afakija tika koriǵēta ar kontaktlēcām, un bērniem, kuriem bija implantētas intraokulārās lēcas. IATS atrada, ka acīs ar IOL implantācijām biežāk atkārtojās lēcas reproliferācijas, radot redzes ass apduļ̧̣ojumus, kā arī bija biežākas atkārtotas operācijas [49]. IOLu2 pētījums pētīja lielu Apvienotās Karalistes un Īrijas bilaterālas un unilaterālas iedzimtas kataraktas pacientu kohortu, kam kataraktas operācija tika veikta agrāk nekā divu gadu vecumā. Bērniem ar bilaterālu kataraktu, operējot viņus agrīni, gadu pēc operācijām tika atrasta labāku redzes rezultātu tendence [105]. Taču, līdzīgi kā zīdaiņu afakijas ārstēšanas pētījumā (IATS), bērniem ar IOL implantācijām tika novērots biežāks reoperāciju skaits [94, 105].

Ja salīdzinām minētos pētîjumus ar mūsu pētījumu par iedzimtu kataraktu un pseidofakiskas acs refrakcijas izmaiņām, sākotnēji varam atrast vairākas kontroversijas. Uzskatāmākā no tām saistīta ar intraokulārās lēcas implantāciju agrīna vecuma (1-6 mēneši) bērniem, ko varētu sākotnēji uzskatīt kā neatbilstošu un nepareizu. Tomēr gribu aizstāvēt gan Latvijā noteiktajā laikā izvēlēto iedzimtas kataraktas ārstēšanas taktiku, gan pētījuma rezultātus, kas ir nozīmīgi gan retu slimību ārstēšanas izpētes jomā, gan noderīgi klīnicistiem, studentiem un rezidentiem, kas ārstēs iedzimtu kataraktu vai mācīsies un iepazīs šo slimību.

Pasaules Pediatriskās oftalmoloğijas asociācijas (World Society of Pediatric Opthalmology and Strabismus, WSPOS) organizētajā Pediatriskās oftalmologijas subspecialitātes dienā 2018. gada 21. septembrī WSPOS valdes priekšsēdētājs prof. Ken K.Nischal atzīmēja, ka "uz pierādījumiem balstītie pētījumi nav ǵeneralizēti obligāti kā obligātas vadlīnijas visā pasaulē. Liela nozīme ir arī katras valsts, reǵiona, kontinenta sociāli ekonomiskajam stāvoklim un konkrētās veselības aizsardzības sistēmas iespējām. Katrs noteikts pētījums liecina par noteiktas vietas, noteiktu apstākḷu uz pierādījumiem balstītiem noteiktiem rezultātiem”. (Pasaules Pediatriskās oftalmoloǵijas asociācijas pediatrijas subspecialitātes diena, Vīne, 21.09.2018.) 


\section{ZINĀTNISKĀ DARBA SECINĀJUMI}

1. Iedzimta katarakta ir heterogēna, unikāla sistēma, ko raksturo dažādi kataraktas sākšanās laiki, morfologiija un lateralitāte. Šie iedzimtas kataraktas raksturojošie lielumi ietekmē ķirurǵiskas korekcijas laiku, veidu un refrakcijas izmaiṇu - miopiskās novirzes lielumu.

2. Mazs acs aksiālais garums un agrīns bērna vecums iedzimtas kataraktas ķirurğiskas korekcijas un intraokulāras lēcas implantācijas laikā palielina acs refrakcijas izmaiṇu - miopiskās novirzes - lielumu un dispersiju. Ja pseidofakiskas acs aksiālais garums iedzimtas kataraktas ķirurǵiskas korekcijas laikā ir līdz 19 mm, bērnam augot, veidosies lielas, izkliedētas un neparedzamas acs refrakcijas izmaiņas. Ja pseidofakiskas acs aksiālais garums būs $19 \mathrm{~mm}$ un lielāks, acs refrakcijas izmaiņas būs paredzamas un statistiski ticami daudz mazākas.

3. Intraokulārās lēcas mērķa refrakcijas atšķirīgas taktikas (emetropa un hipermetropa IOL mērķa refrakcija) neietekmē miopiskās novirzes lielumu, IOL individuālais stiprums ietekmē un korelē ar miopiskās novirzes lielumu. 


\section{PRAKTISKĀS REKOMENDĀCIJAS}

\section{1. rekomendācija}

\section{Acs ar kataraktu atklāšana un klīniskā izmeklēšana}

(neonatologs, gimenes ārsts, oftalmologs, bērnu oftalmologs).

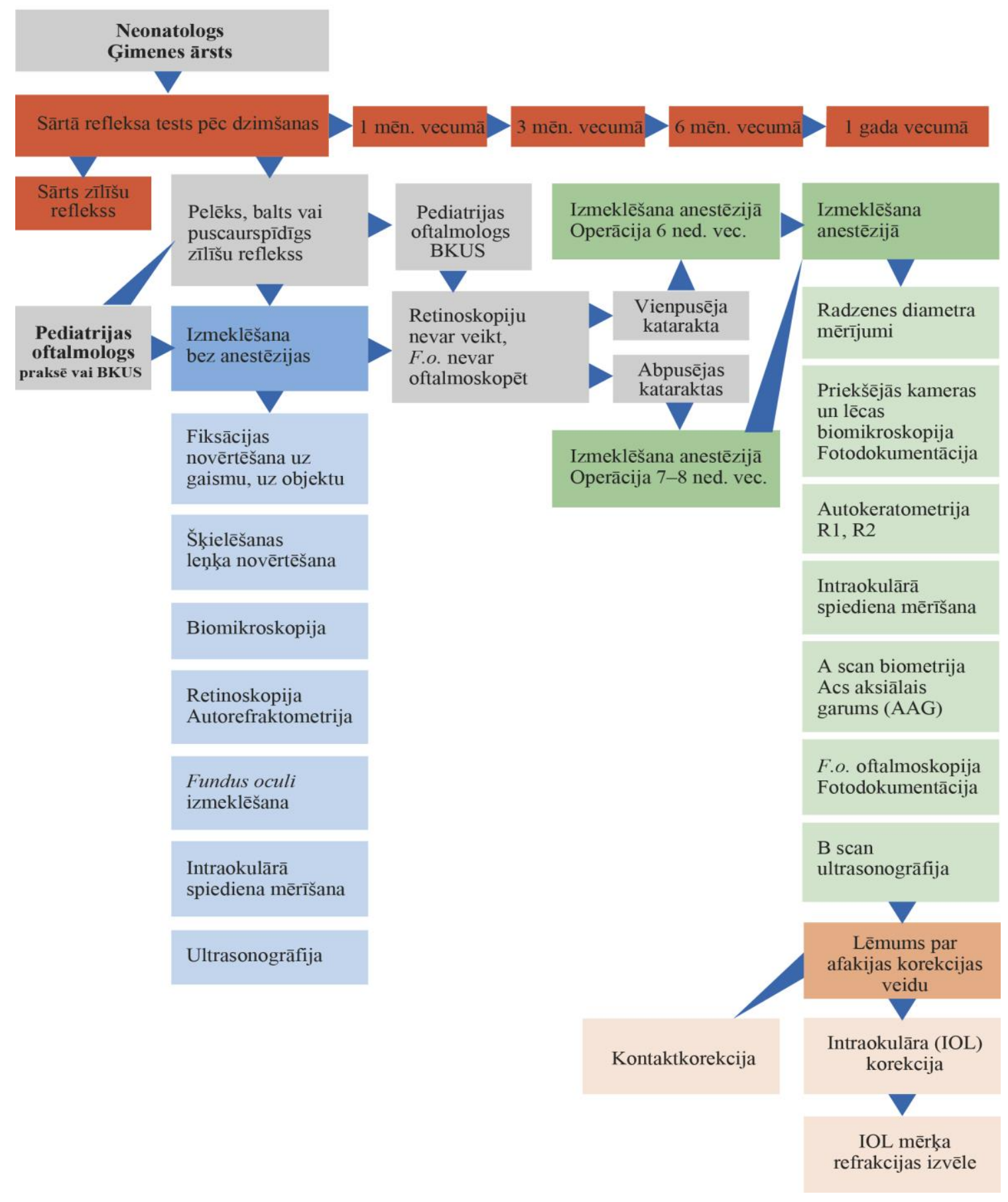




\section{2. rekomendācija}

\section{Klīnskais ceḷš iedzimtas kataraktas diagnostikā}

(bērnu oftalmologs, neonatologs, medicīnas genētiķis).

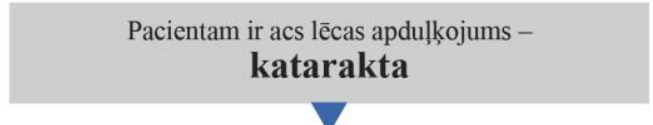

\section{Klīniskais novērtējums}

1. Oftalmologiskais: redzes asums; radzenes diametrs; citas priekšējā segmenta anomālijas (mug. embriotoksons, iridokorneālā adhēzija); intraokulārais spiediens; cikloplègiskā refrakcija; apdulknojuma redzes nozīmība (apduḷkojuma pakāpe, lielums, novietojums); mugurējais segments (B scan izmeklēšana, ja nav redzamības) 2. Vispārīgais

\section{Taktika, analīzes (oftalmologs, neonatologs, pediatrs)}

Pacients $<1$ mēn. neonatologa konsultācija un lēmums par analīzēm

Pacients >1 mēn. - ǵimenes ārsta vai pediatra konsultācija un lēmums par analīzēm

Analīzes:

1) urīna analīze

2) pilna asins aina

3) asins bioḳ̄imija kreatīnkināze, urea; ALAT; ASAT; kalcijs; fosfors; feritīns; glikoze serumā; holesterīna frakcijas

4) TORCH titri (toksoplazmoze, herpes simplex, masalas, masaliņas, citomegalovīruss

5) treponēmas skrīninga tests, ja pozitīvs- tad apstiprinošais FTA-ABS

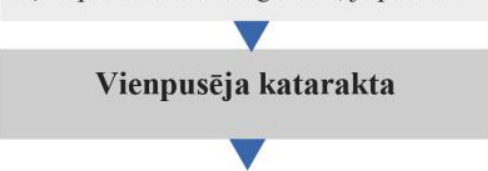

\section{Slimības anamnēze}

1. Perinatālā un postnatālā anamnēze

2. Kataraktas sākšanās laiks

3. Slimỉbas ǵimenē (oftalmoloǵiskās un citas)

4. Jautājums par traumu, radiāciju

Oftalmologisiskās terapijas izvēle specifiskās terapijas izvēle atkarībā no kataraktas etiologijas

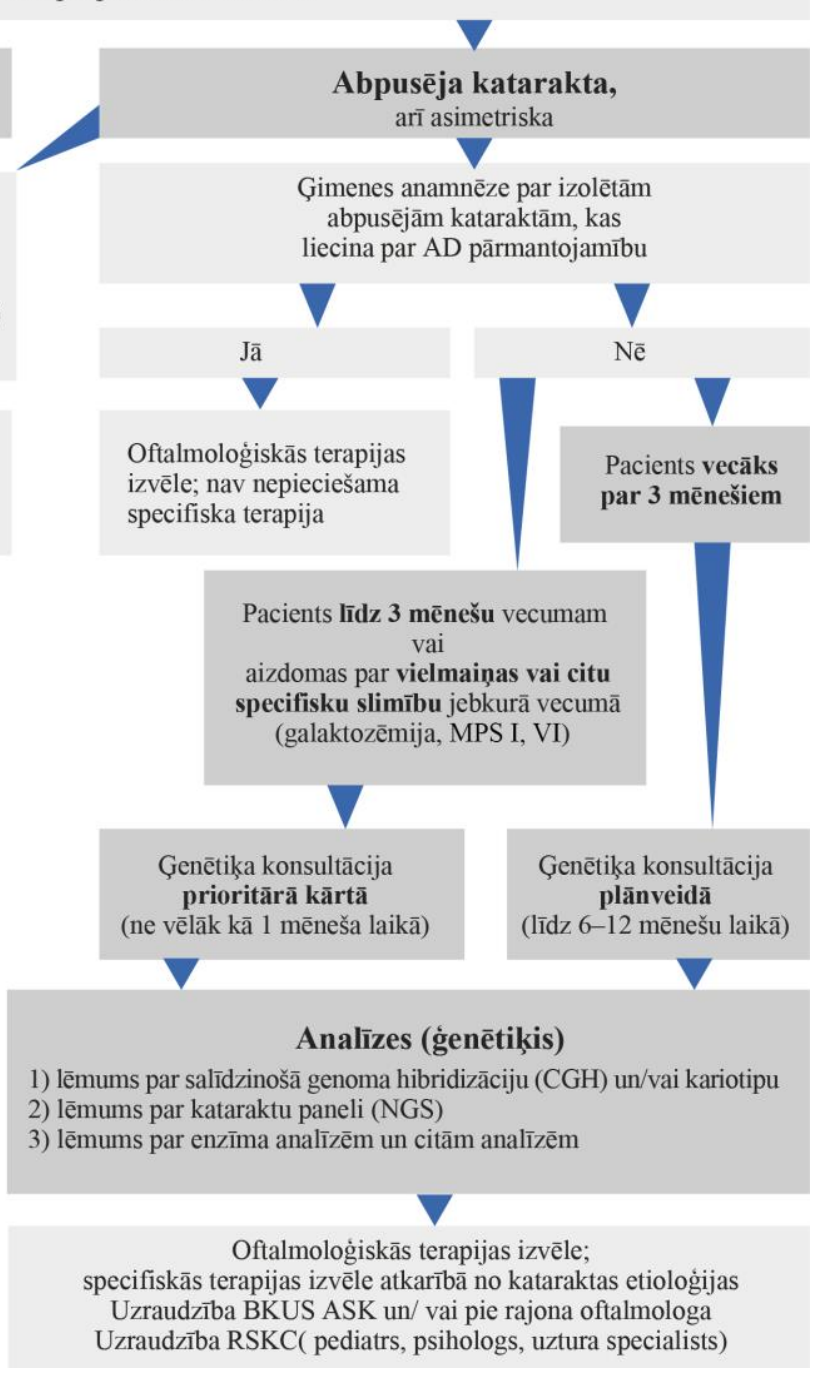




\section{3. rekomendācija}

\section{Iedzimtas kataraktas ķirurğiskas korekcijas veids atkarībā no pacienta acs aksiālā garuma kataraktas ķirurğiskas korekcijas laikā}

Pēcoperācijas medikamentozā terapija un novērošanas biežums (pediatrijas oftalmologs, oftalmologijjas mikroḳirurgs).

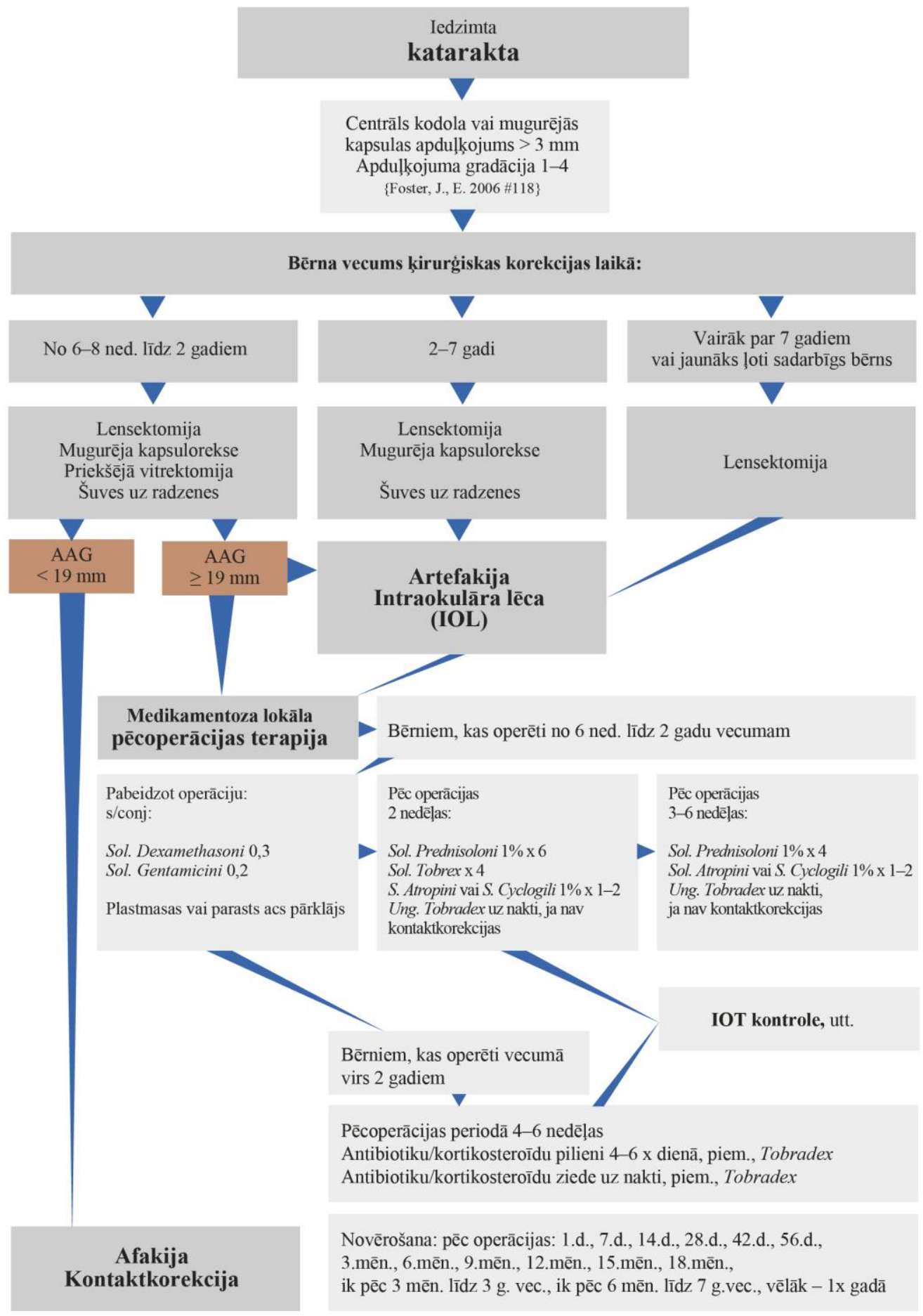




\section{PERSPEKTĪVIE PĒTĪJUMA VIRZIENI}

Balstoties uz izveidoto iedzimtas redzei nozīmīgas kataraktas datu bāzi, Bērnu klīniskās universitātes slimnīcas Acu slimību klīnikā uzsāktie un iecerētie pētîjumi:

- Acs aksiālā garuma un acs radzenes izliekuma izmaiņas iedzimtas kataraktas pacientiem pēc kataraktas ekstrakcijas operācijām ar un bez intraokulārās lēcas implantāciju, to korelācija ar acs refrakcijas izmaiṇām, bērnam augot.

- Bērna vecuma un operācijas veida ietekme uz sekundāras kataraktas veidošanos.

- Redzes, kontrastredzes un binokulārās redzes attīstība iedzimtas kataraktas acīs pēc kataraktas ekstrakcijas operācijām ar un bez intraokulārās lēcas implantāciju.

- Oklūziju nozīme abpusēju un vienpusēju kongenitālu un infantilu iedzimtu kataraktu acu redzes attīstībā.

- Dažādu redzes korekcijas veidu (monofokālas, bifokālas, progresīvas, kontaktkorekcijas) priekšrocības un trūkumi pseidofakisku acu atlieku refrakcijas kḷūdu korekcijā.

- HPO (human phenotype ontology) un ORDO (Orphanet rare disease ontology) klasifikāciju noderīgums iedzimtas kataraktas raksturojumā, izmeklēšanā un ārstēšanā.

- Iedzimtas redzei nozīmīgas kataraktas ǵenētisko cēloṇu izpēte Latvijā. 


\section{PROMOCIJAS DARBA APROBĀCIJA}

\section{Stenda referāti}

1. Pētījums par iedzimtu kataraktu skrīninga metodi un iespējām. RSU 2013. gada zinātniskā konference, Rīga, 2013. gada 21.-22. martā.

2. Prognosis for vision development in patients after childhood cataract surgery depending on cataract morphology, age of onset, IOL target power and post-operative complications. European Paediatric Ophthalmological Society $201440^{\text {st }}$ Annual Meeting programme and abstract book, Barcelona, 2014. gada 7.-8. novembrī

3. Etiology of pediatric cataract in Children's University Hospital in Latvia. 40 ${ }^{\text {st }}$ European Paediatric Ophthalmological Society 2014, 40 ${ }^{\text {st }}$ Annual Meeting programme and abstract book, Barcelona, 2014. gada 7.-8. novembrī.

4. Salīdzinošs redzes attīstības novērtējums pacientiem ar operētu iedzimto kataraktu atkarībā no kataraktas morfologisiskā tipa, attīstības sākuma laika, implantētās IOL mērķa stipruma un pēcoperācijas komplikācijām. RSU 2015. gada Zinātniskā konference, Rìga, 2015. gada 26.-27. martā.

5. Myopic shift in children after intraocular lens implantation. 115. DOG-Kongress 28.09. 01.10.2017. Berlīne, 2017. gada 28. septembrī. Atzinības balva (DOG-2017 Travel Award).

\section{Ziṇojumi par promocijas darbu un tā rezultātiem}

1. Children lens abnormalities, reasons, diagnostic and treetment in Latvia. 107. Vācijas Oftalmologu biedrības (DOG) konference, Leipciga, 2009. gada 26. septembrī.

2. Iedzimtas kataraktas operāciju retrospektīva analīze. RSU 2010. gada zinātniskāa konference, Rīga, 2010. gada 19. martā.

3. Accuracy of intraocular lens power calculation in paediatric cataract surgery. XIII Forum Ophthalmologicum Balticum, Viļñ̄a, 2010. gada 21. augustā.

4. IOL aprēķini iedzimtu kataraktu ekstrakcijas ķirurǵijā. RSU 2011. gada zinātniskāa konference, Rìga, 2011. gada 15. aprīlì.

5. Postoperative refraction management in congenital cataract patients. 2nd Baltic Conference Paediatric Ophthalmology: the art and the science 2001. Lifelong benefits to child and family, Rīga, 2011. gada 16. septembrī. 
6. Strange cataracts, corneal and vitreoretinal lesions: suprising diagnosis. $X X X X$ Ziemeļvalstu Oftalmologu konference, Helsinki, 2012. gada 26. augustā.

7. Comparative analysis of vision development in patients with congenital cataract in relation to cataract surgery time and IOL target power. XIV Forum Ophthalmologicum Balticum, Tallina, 2013. gada 24. augustā.

8. The comparative assessment of vision development in patients with congenital cataracts depends on cataract morphology, cataract surgery time and IOL target power. 111. DOGKongress, Berlin, 19.-22.09.2013., atzinības balva (DOG Travel Award).

9. Salīdzinošs redzes attīstības novērtējums pacientiem ar operētu iedzimto kataraktu atkarībā no kataraktas morfoloğiskā tipa, attīstības sākuma laika, implantētās IOL mērķa stipruma un pēcoperācijas komplikācijām. RSU Zinātniskā konference, Rīga, 2015. gada 11. aprīlī.

10. Treatment of childhood cataract within integral ethics. European Paediatric Ophthalmological Society $41^{\text {st }}$ Annual Meeting, St. Petersburg, 26. jūnijā.

11. Congenital cataract surgery and IOL implantation. Child's eye refraction changes. Baltic Eye Surgeons Talk Show. BEST VOL. 6., Jürmala, 2018. gada 25. augustā.

\section{Tèzes}

1. Valeina, S., Laganovska G., Sepetiene S., Valeina I., Danilane A. (2010). Accuracy of IOL power calculation in pediatric cataract surgery. XIII Forum Ophthalmologicum Balticum Final Programme and Abstract book, August 20.-22.2010, Vilnius, 39. 1pp.

2. Valeiņa, S., Pastare, M., Klindžāne, M. (2013). Pētījums par iedzimtu kataraktu skrīninga metodi un iespējām. Rīgas Stradiņa universitāte. 2013. gada Zinātniskā konference: Tēzes. Rīga: RSU, 227. lpp.

3. Valeina, S., Sepetiene, S. (2013). Comparative analysis of vision development in patients with congenital cataract in relation to cataract surgery time and IOL target power. XIV Forum Ophthalmologicum Balticum Final Programme and Abstract book; August 23-24, 2013, Tallinn, 68.1pp.

4. Valeina, S., Sepetiene, S., Radecka, L., Vanags, J., Laganovska, G. (2013). The comparative assessment of vision development in patients with congenital cataracts depends on cataract morphology, cataract surgery time and IOL target power. 111. DOG- 
Kongress 19.-22-09.2013. online thesis; Berlin; 64 lpp., atzinibas balva (DOG Travel Award).

5. Valeina, S., Sepetiene, S., Laganovska, G., Vanags, J., Radecka, L., Erts, R. (2014). Prognosis for vision development in patients after childhood cataract surgery depending on cataract morphology, age of onset, IOL target power and post-operative complications. European Paediatric Ophthalmological Society $201440^{\text {st }}$ Annual Meeting programme and abstract book, Barcelona, 101. lpp.

6. Stūre, E. A., Valeina, S. (2014) Etiology of pediatric cataract in Children's University Hospital in Latvia. European Paediatric Ophthalmological Society 2014, 40 ${ }^{\text {st }}$ Annual Meeting programme and abstract book, Barcelona, 100. 1pp.

7. Valeina, S. (2015). Cure of childhood cataract within integral ethics. European Paediatric Ophthalmological Society $201541^{\text {st }}$ Annual Meeting programme and abstract book,

St. Petersburg, 47. lpp.

8. Stūre, E. A., Valeina, S. (2015). Time of diagnosis, etiology and morphology of pediatric cataracts. European Paediatric Ophthalmological Society 2015 41-st Annual Meeting programme and abstract book, St. Petersburg, 67. 1pp.

9. Valeina, S. (2017). Myopic shift in children after intraocular lens implantation. 115. DOG-Kongress 28.09.-1.10.2017.. online thesis, Berlin, 125 lpp., atzinības balva (DOG Travel Award).

\section{Publikācijas}

1. Valeina, S., Sepetiene, S., Laganovska, G., Radecka, L., Vanags, J., Erts, R., Meskovska, Z., Sture, E. A. Analysis of Vision Development in Patients after Childhood Cataract Surgery. Acta Chirurgica Latviensis, 2015 (15/1), 12-17.

2. Valeina, S., Krumina, Z., Sepetiene, S., Andzane, G., Sture, E. A., Taylor, D. Fabricated or Induced Illness Presenting as Recurrent Corneal Lesions, Cataracts, and Uveitis. J Pediatr Ophthalmol Strabismus [04 Feb 2016, 53 Online:e 6-e11](PMID:27007397)

3. Valeina, S., Heede, S., Erts, R., Sepetiene, S., Skaistkalne, E., Radecka, L., Vanags J., Laganovska, G. Factors influencing myopic shift in children after intraocular lens 
implantation. European Journal of Ophthalmology, EJO-D-18-00722R1 | Accepted for publication on Dec 09, 2018- [EMID:21f8f03f75ef32d3] 


\section{IZMANTOTĀ LITERATŪRA}

1. Amaya, I., Taylor, D., Russell-Eggitt, I., et al. (2003). The morphology and natural history of childhood cataracts. Surv Ophthalmol. 48, 125-144.

2. Andreo, L. K., Wilson, M. E., Saunders, R. A. (1997). Predictive value of regression and theoretical IOL formulas in pediatric intraocular lens implantation. J Pediatr Ophthalmol Strabismus. 34, 240 243.

3. Arun, V., Noble, A., G., et al. (2007). Cataracts in congenital toxoplasmosis. J AAPOS. 11, 551-554.

4. Ashworth, J., Biswas, S. Perioperative Care of the Child with Congenital Cataract-Intraoperative and Post-operative Medication. In: Lloyd, I. C, Lambert, S. C., editors. (2017). Congenital Cataract: A Concise Guide to Diagnosis and Management. Switzerland: Springer International Publishing. $143-149$.

5. Ashworth, J., Maino, A. P., Biswas, S., Lloyd, I. C. (2007). Refractive outcomes after primary intraocular lens implantation in infants. Br J Ophthalmol. 91, 596-599. doi:10.1136/bjo.2006.108571.

6. Astle, W. F., Ingram, A. D., Isaza, G. M., Echeverri, P. (2007). Paediatric pseudophakia: analysis of intraocular lens power and myopic shift. Clinical and Experimental Ophthalmology. 35, 244-251. doi:10.1111/j.1442-9071.2006.01446.x.

7. Barry, J. S., Ewings, P., Gibbon, C., Quinn, A. G. (2006). Refractive outcomes after cataract surgery with primary lens implantation in infants. Br J Ophthalmol. 90, 1386-1389.

8. Beigi, B., O'Keefe, M., Bowell, R., et al. (1993). Ophthalmic findings in classical. Br J Ophthalmol. 77, 162-164.

9. Bhatti, T. R., Dott, M., Yoon, P. W., Moore, C. A., Gambrell, D., Rasmussen, S. A. (2003). Descriptive epidemiology of infantile cataracts in metropolitan Atlanta, GA, 1968-1998. Descriptive epidemiology of infantile cataracts in metropolitan Atlanta, GA, 1968-1998. Arch Pediatr Adolesc Med. 157, 341-347.

10. Birch, E. E., Cheng, C.: Stager, D. R., Weakley, D. R., Stager, D. R. (2009). The critical period for surgical treatment of dense congenital bilateral cataracts. J AAPOS. 13, 67-71.

11. Bothun, E. D. Strabismus in Children with Cataracts. In: Lloyd, I. C., Lambert, S. C., editors. (2017). Congenital Cataract:: A Concise Guide to Diagnosis and Management. Switzerland: Springer International Publishing. 209-213.

12. Bresson-Dumont, H. (2009). Intraocular pressure measurement in children. J Fr Ophthtalmol. 32, 176-181. doi:10.1016/j.jfo.2009.03.008.

13. Chak, M., Rahi, J. S. (2007). The health-related quality of life of children with congenital cataract: fi ndings of the British Congenital Cataract Study. Br J Ophthalmol. 91, 922-926.

14. Chak, M., Wade, A., Rahi, J. S. (2006). Long-term visual acuity and its predictors after surgery for congenital cataract: fi ndings of the British congenital cataract study. Invest Ophthalmol Vis Sci. 47, 4262-4269.

15. Chen, J., Wang, Q., et al. (2017). Molecular Genetic Analysis of Pakistani Families With Autosomal Recessive Congenital Cataracts by Homozygosity Screening. Invest Ophthalmol Vis Sci. 58, 22072217.

16. Chen, T. C., Bhatia, L. S., Walton, D. S. (2005). Complications of pediatric lensectomy in 193 eyes. Ophthalmic Surg Lasers Imaging. 36, 6-13.

17. Chen, T. C., Walton, D. S., Lini, S., Bhatia, L. S. (2004). Aphakic glaucoma after congenital cataract surgery. Arch Ophthalmol. 122, 1819-1825. doi:10.1001/archopht.122.12.1819. 
18. Choi, J., Kim, J. H., Kim, S. J., Yu, Y. S. (2012). Clinical characteristics, course, and visual prognosis of partial cataracts that seem to be visually insignificant in children. J AAPOS. 16, 161-163.

19. Churchill, A., Graw, J. (2011). Clinical and experimental advances in congenital and paediatric cataracts. Philos oc Lond B Biol Sci. 366, 1234-1249. doi:10.1098/rstb.2010.0227.

20. Crouch E. R., Crouch E. R.(Jr), Pressman, S. H. (2002). Prospective Analysis of Pediatric Pseudophakia: Myopic Shift and Postoperative Outcomes. J AAPOS. 6, 277-282.

21. Dahan, E., Drusedau, M. U. (1997). Choice of lens and dioptric power in pediatric pseudophakia. J Cataract Refract Surg. 23, 618-623.

22. Daien,V., Le Pape, A., Heve, D., Villain, M., Bremond, G. D. (2017). Collaborators of the Epidemiology and Safety Programm (EPISAFE). Ophthalmic Res. 58, 114-116. doi:10.1159/000473701.

23. Dālmane, A., Kalniņa, M., Koroḷova, O., Kukaine, S. (2006). Cilvēka embriogenenēze.

24. Dixon-Woods, M., Awan, M., Gottlob, I. (2006). Why is compliance with occlusion therapy for amblyopia so hard? A qualitative study. Arch Dis Child. 91, 491-494. doi:10.1136/adc.2005.090373.

25. Drews-Botsch, C. Amblyopia Therapy and Occlusion Regimens. In: Lloyd, I. C., Lambert, S. C. editors. (2017). Congenital Cataract:: A Concise Guide to Diagnosis and Management. Switzerland: Springer International Publishing. 151-163.

26. Elston, J. S., Timms, C. (1992). Clinical evidence for the onset of the sensitive period in infancy. Br J Ophthalmol. 76, 327-328.

27. Enyedi, L. B., Peterseim, M. W., Freedman, S. F., Buckley, E. G. (1998). Refractive changes after pediatric intraocular lens implantation. Am J Ophthalmol. 126, 772-781.

28. Fan, D. S., Rao, S. K., Yu, C. B., Wong, C. Y., Lam, D. S. (2006). Changes in refraction and ocular dimensions after cataract surgery and primary intraocular lens implantation in infants. $J$ Cataract Refract Surg. 32, 1104-1108.

29. Fitzpatrick, D. R. Developmental biology of the eye. In: Hoyt, C. S., Taylor, D., editors. (2013). Pediatric Ophthalmology and Strabismus. $3^{\text {th }}$ ed. 16-22.

30. Foster, A., Gilbert, C., Rahi, J. (1997). Epidemiology of cataract in childhood: a global perspective. $J$ Cataract Refract Surg. 23, 601-604.

31. Foster, J. E., Abadi, R. V., Muldoon, M., Lloyd, I. C. (2006). Grading infantile cataracts. Ophthal.Physiol.Opt. 26, 372-379.

32. Francis, P. J., Berry, V., Bhattacharya, S. S., Moore, A. T. (2000). The genetics of childhood cataract. J Med Genet. 37.

33. Fulton, A. B., Hansen, R. M., Moskowitz, A., Mayer, D. L. Normal and abnormal visual development. In: Hoyt, C. S., Taylor, D., editors. (2013). Pediatric Ophthalmology and Strabismus. $3^{\text {th }}$ ed. $23-30$.

34. Gilbert, C, editor. (2009). Pediatric Ophthalmology: Worldwide causes of blindness in children. $47^{\text {th }}$ ed.

35. Gill, D., Klose, R., Munier, F. L., et al. (2000). Genetic heterogeneity of the Coppock-like cataract: a mutation in CRYBB2 on chromosome 22q11.2. Invest Ophthalmol Vis Sci. 41, 159-165.

36. Gillespie, R. L., Black, G. C. M. The Role of Molecular Genetics in the Assessment of Children with Congenital Cataract. In: Lloyd, I. C., Lambert, S. C., editors. (2017). Congenital Cataract: A Concise Guide to Diagnosis and Management. Switzerland: Springer International Publishing. 29-54.

37. Gordon, R. A., Donzis, P. B. (1985). Refractive development of the human eye. Arch Ophthalmol. $103,785-789$. 
38. Gouws, P., Hussin, H. M., Markham, R. H. C. (2006). Long term results of primary posterior chamber intraocular lens implantation for congenital cataract in the first year of life. Br J Ophthalmol. 90, 975978.

39. Griener, E. D., Dahan, E., Lambert, S. R. (1999). Effect of age at time of cataract surgery on subsequent axial length growth in infant eyes. J Cataract Refract Surg. 25, 1209-1213.

40. Grigg, J., Fenerty, C. Glaucoma Following Cataract Surgery in Aphakic or Pseudophakic Children. In: Lloyd, I. C., Lambert, S. C. editors. (2017). Congenital Cataract: A Concise Guide to Diagnosis and Management. Switzerland: Springer International Publishing. 181-193.

41. Grigg, J., Fenerty, C. Glaucoma Following Cataract Surgery in Aphakic or Pseudophakic Children. In: Lloyd, I. C., Lambert, S. C. editors. (2017). Congenital Cataract: A Concise Guide to Diagnosis and Management. Switzerland: Springer International Publishing. 180-193.

42. Haargaard, B., Wohlfahrt, J., Rosenberg, T., Fledelius, H. C., Melbye, M. (2005). Risk factors for idiopathic congenital/ infantile cataract. Invest Ophthalmol Vis Sci. 46, 3067-3073.

43. Hartmann, E. E. Baseline Predictors of Visual Outcome. In: Lloyd, I. C., Lambert, S. C. editors. (2017). Congenital Cataract: A Concise Guide to Diagnosis and Management. Switzerland: Springer International Publishing. 67-72.

44. Hartmann, E. E., Lynn, M. J., Lambert, S. R. (2015). Infant Aphakia Treatment Study Group. Baseline Characteristics of the Infant Aphakia Treatment Study: predicting recognition acuity at 4.5 years of age. Invest Ophthalmol Vis Sci. 56, 388-395.

45. Hejtmancik, J. F. (2009). Congenital Cataracts and their Molecular Genetics. Semin Cell Dev Biol. 19, 134-149.

46. Hoevenaars, N. E., Polling, J. R., Wolfs, R. C. (2011). Prediction error and myopic shift after intraocular lens implantation in paediatric cataract patients. $\mathrm{Br} J$ Ophthalmol. 95, 1082-1085. doi:10.1136/bjo.2010.183566.

47. Hoyt, C. S., Taylor, D. editors. (2013). Pediatric Ophthalmology and Strabismus. $339^{\text {th }}$ ed.

48. Hung, L. F., Crawford, M. L., Smith, E. L. (1995). Spectacle lenses alter eye growth and the refractive status of young monkeys. Nat Med. 1, 761-765.

49. Infant Aphakia Treatment Study Group, Lambert, S. R., Lynn, M. J., et al. (2014). Comparison of Contact Lens and Intraocular Lens Correction of Monocular Aphakia During Infancy: A Randomized Clinical Trial of HOTV Optotype Acuity at Age 4.5 Years and Clinical Findings at Age 5 Years. Jama Ophthalmol. 132, 676-682.

50. Jain, I. S., Pillay, P., Gangwar, D. N., et al. (1983). Congenital cataract: Etiology and morphology. J Pediatr Ophthalmol Strabismus. 238-242.

51. Kanski, J. J. (2007). Clinical Ophthalmology: A Systematic Approach.

52. Kong. L., Fry, M., Al-Samarraie, M., Gilbert, C., Steinkuller, P. G. (2012). An update on progress and the changing epidemiology of causes of childhood blindness worldwide. J AAPOS. 16, 501-507.

53. Kraus, R. H., Trivedi, R. H., Deacon, B. S., Wilson, M. E. Managment of Infantile and Childhood Cataracts. In: Traboulsi, E. I., Utz, V. M editors. (2016). Practical Management of Pediatric Ocular Disorders and Strabismus. 183-190.

54. Lambert, S. R. (1998). Ocular growth in early childhood: Implications for pediatric cataract surgery. Op Techn Cataract Refract Surg. 1, 159-164.

55. Lambert, S. R. Childhood cataracts. In: Hoyt, C. S., Taylor, D., editors. (2013). Pediatric Ophthalmology and Strabismus. $339^{\text {th }}$ ed. 339-352. 
56. Lambert, S. R. Visual Outcomes. In: Lloyd, I. C., Lambert, S. C., editors. (2017). Congenital Cataract:: A Concise Guide to Diagnosis and Management. Switzerland: Springer International Publishing. 197-218.

57. Lambert, S. R., Buckley, E. G., Plager, D. A., Medow, N. B., Wilson, M. E. (1999). Unilateral intraocular lens implantation in the first year of life. J AAPOS. 3, 344-349.

58. Lambert, S. R., Cotsonis, G. A., DuBois, L. G., Wilson, M. E., Plager, D. A., Buckley, E. G., et al. (2016). Comparison of the rate of refractive growth in aphakic eyes versus pseudophakic eyes in the Infant Aphakia Treatment Study. $J$ Cataract Refract Surg. 42, 1768-1773. doi:10.1016/j.jcrs.2016.09.021.

59. Lambert, S. R., Drack, A. V. (1996). Infantile cataracts. Surv Ophthalmol. doi:10.1016/SOO396257(96)82011-X.

60. Lambert, S. R., Fernandes, M., Drews-Botsch, C., Tigges, M. (1996). Pseudophakia Retards Axial Elongation in Neonatal Monkey Eyes. Invest Ophthalmol Vis Sci. 37, 451-458.

61. Lambert, S. R., Lynn, M. J., Drews-Botsch, C., et al. (2001). A comparison of grating visual acuity, strabismus, and reoperation outcomes among infants with aphakia and pseudophakia after unilateral cataract surgery during the fi rst six months of life. J AAPOS. 5.

62. Lambert, S. R., Lynn, M. J., DuBois, L. G., Cotsonis, G. A., Hartmann, E. E., Wilson, M. E. (2012). Infant Aphakia Treatment Study Groups. Axial elongation following cataract surgery during the first year of life in the Infant Aphakia Treatment Study. Invest Ophthalmol Vis Sci. 53, 7539-7545.

63. Lambert, S. R., Lynn, M. J., Hartmann, E. E., DuBois, L. G., Drews-Botsch, C., Freedman, S. F., et al. (2014). Comparison of Contact Lens and Intraocular Lens Correction of Monocular Aphakia During Infancy: A Randomized Clinical Trial of HOTV Optotype Acuity at Age 4.5 Years and Clinical Findings at Age 5 Years. Jama Ophthalmol. 132, 676-682. doi:10.1001/jamaophthalmol.2014.531.

64. Lang, R. A. (2004). Pathways regulating lens induction in the mouse. Int J Dev Biol. 783-791.

65. Larsen, J. S. (1971). The sagital growth of the eye. Ultrasonic measurement of the axial lenghth of the eye from birth to puberty. Acta Ophthalmol. 49, 873-886.

66. Lavin, C. W., McKeown, C. (1993). The oculocerebrorenal syndrome of Lowe. Int Ophthalmol Clin. 33, 179-191.

67. Letocha, C. E., Pavlin, C. J. (1999). Follow-up of 3 patients with Ridley intraocular lens implantation. J Cataract Refract Surg. 587-591.

68. Lim, Z., Rubab, S., Chan, Y. H., Levin, A. V. (2010). Pediatric Cataract: The Toronto ExperienceEtiology. Am J Ophthalmol. 149, 887-892.

69. Liu, Z., Long, E., Chen, J., Lin, Z., Lin, D., et al. (2016). Developmental profile of ocular refraction in patients with congenital cataract: a prospective cohort study. The Lancet. doi:10.1016/S01406736(16)31981-X.

70. Lloyd, I. C., Ashworth, J., Biswas, S., Abadi, R. V. (2007). Advances in the management of congenital and infantile cataract. Eye. 21, 1301-1309.

71. Lloyd, I. C., Lambert, S. C., editors. (2017). Congenital Cataract: A Concise Guide to Diagnosis and Management. Switzerland: Springer International Publishing.

72. Lorenz, B., Wörle, J., Friedl, N., Hasenfratz, G. (1993). Ocular growth in infant aphakia. Bilateral versus unilateral congenital cataracts. Ophthalmic Paediatr Genet. 14, 177-188.

73. LV MK noteikumi. Ministru kabineta 2006. gada 4. aprīịa noteikumi Nr. 265, 93. pielikums, 2006.

74. Mann, I. (1964). The development of the human eye. 
75. Masket, Se. (1991). Consultation Section. J Cataract Refract Surg. 17, 512-518.

76. McAvoy, J. W., Chamberlain, C. G., Iongh, R. U., et al. (1999). Lens development. Eye. 13, 425-437.

77. McClatchey, S. K., Parks, M. M. (1997). Myopic shift after cataract removal in childhood. J Pediatr Ophthalmol Strabismus. 34, 88-95.

78. McClatchey, S. K., Parks, M. M. (1997). Theoretic refractive changes after lens implantation in childhood. Ophthalmology. 104, 1744-1751.

79. McClatchey, S. K. D. E., Maselli, E., Gimbel, H. V., Wilson, M. E., Lambert, S. R., Buckley, E. G., et al. (2000). A comparison of the rate of refractive growth in pediatric aphakic and pseudophakic eyes. Ophthalmology.107, 118-122.

80. Medsinge, A., Nischal, K. K. (2015). Pediatric cataract: Challenges and future directions. Clin Ophthalmol. 9, 77-90.

81. Merin, S., Crawford, J. S. (1971). Hypoglicemia and infantile cataract. Arch Ophthalmol. 86, 495498.

82. Morrison, D. G. Morphology of Congenital Cataracts. In: Lloyd, I. C., Lambert, S. C., editors. (2017). Congenital Cataract: A Concise Guide to Diagnosis and Management. Switzerland: Springer International Publishing. 55-67.

83. Muhsin, E., Eren, Ç., Sena, S. (2017). Comparison of Intraocular Pressure Measurements in Healthy Pediatric Patients using Three Types of Tonometers. Turk J Ophthalmol. 47, 1-4. doi:10.4274/tjo.92593.

84. O’Hara, M. A. (2012). Pediatric intraocular lens power calculations. Curr Opin Ophthalmol. 23, 388393.

85. O'Keefe, M., Fenton, S., Lanigan, B. (2001). Visual outcomes and complications of posterior chamber intraocular lens implantation in the first year of life. J Cataract Refract Surg. 27, 20062011.

86. Pandey, S. K. Embryology and Anatomy of the Human Crysralline Lens. In: Wilson, M. E., Trivedi, R. H., Pandey, S. K., editors. (2005). Pediatric Cataract Surgery: Lippincot Williams\&Wilkins. 1-5.

87. Pandey, S. K., Wilson, M. Etiology and Morphology of Pediatric Cataracts. In: Wilson, M., Trivedi, R. H., Pandey, S. K., editors. (2005). Pediatric Cataract Surgery: Techniques, complications, and Management. Etiology and Morphology of Pediatric Cataracts. 6-13.

88. Papastergiou, G. I., Schmid, G. F., Laties, A. M., Pendrak, K., Lin, T., Stone, R. A. (1998). Induction of axial eye elongation and myopic refractive shift in one-year-old chickens. Vision Research. 38, $1883-1888$.

89. Parks, M. M. (1982). Visual results in aphakic children. Am J Ophthalmol. 94, 441-449.

90. Parks, M. M., Johnson, D. A., Reed, G. W. (1993). Long-term visual results andcomplications in children with aphakia: a function of cataract type. Ophthalmology.100, 826-841.

91. Pascolini, D., Mariot, S. P., Pokharel, G. P., et al. (2004). Global update of available data on visual impairment: : a compilation of population-based prevalence studies. Ophthalmic Epidemiol. 11, 67115.

92. Plager, D. A. Complications Following Congenital Cataract Surgery. In: Lloyd, I. C., Lambert, S. C., editors. (2017). Congenital Cataract: A Concise Guide to Diagnosis and Management. Switzerland: Springer International Publishing. 173-179.

93. Plager, D. A., Kipfer, H., Sprunger, D. T., Sondhi, N., Neely, D. E. (2002). Refractive change in pediatric pseudophakia: 6-year follow-up. J Cataract Refract Surg. 28, 810-815. 
94. Plager, D. A., Lynn, M. J., Buckley, E. G., Wilson, M., Lambert, S. R. (2014). Infant Aphakia Treatment Study Group. Complications in the first 5 years following cataract surgery in infants with and without intraocular lens implantation in the Infant Aphakia Treatment Study. Am J Ophthalmol. $58,892-898$.

95. Plager, D. A., Lynn, M. J., Buckley, E. G., Wilson, M. E., Lambert, S. R. (2011). Complications, adverse events and additional intraocular surgery one year after cataract surgery in Infant Aphthakia Treatment Study. Ophthalmology. 118, 2330-2334.

96. Plager, D. A., Yang, S., Sprunger, D.T., Sondhi, N. (2002). Complications in the fi rst year following cataract surgery with and without IOL in infants and older children. J AAPOS. 6, 9-14.

97. Pohjola, S. (1962). Ocular manifestations of idiopathic hypoparathyroidism. Acta Ophthalmol (Copenh). 40, 255-265.

98. Raghu, H., Subhan, Sea. (2004). Herpes simplex virus-associated congenital cataract. Am $J$ Ophthalmol. 138, 313-314.

99. Rahi, J. S., Dezateux, C. (2001). Measuring and interpreting the incidence of congenital ocular anomalies: lessons from national study of congenital catarat in the UK. Invest Ophthalmol Vis Sci. $42,1444-1448$.

100. Sharan, S., Sharma, S., Billson, F. A. (2006). Congenital rubella cataract: a timely reminder in the new millennium? Clin Exp Ophthalmol. 34, 83-84.

101. Shen, W., Vijayan, M., Sivak, J. G. (2005). Inducing Form-Deprivation Myopia in Fish. Investigative Ophthalmology\&Visual Science. 46, 1797-1803. doi:10.1167/iovs.04-1318.

102. Simsek, T., Mutluay, A. H., Elgin, U. (2006). Glaucoma and increased central corneal thickness in aphakic and pseudophakic patients after congenital cataract surgery. British Journal of Ophthalmology. 30(9), 1103-1106.

103. Sloot, F., Hoeve, H. L., de Kroon, M. L., Goedegebure, A., Carlton, J., Griffiths, H. J., Simonsz, H. J. (2015). Inventory of current EU paediatric vision and hearing screening programmes. $J$ Med Screen. 22, 55-64.

104. Solebo, A. L., Rahi, J. S. Epidemiology of Congenital Cataract. In: Lloyd, I. C., Lambert, S. C., editors. (2017). Congenital Cataract:: A Concise Guide to Diagnosis and Management. Switzerland: Springer International Publishing. 15-25.

105. Solebo, A. L., Russell-Eggitt, I., Cumberland, P. M., Rahi, J. S. British Isles Congenital Cataract Interest Group. (2015). Risks and outcomes associated with primary intraocular lens implantation in children under 2 years of age: the IoLunder2 cohort study. Br J Ophthalmol. 99, 1471-1476.

106. Sounders, K. J. (1995). Early refractive development in humans. Surv Ophthalmol. 40, 2017-216.

107. SPKC; Ar notektām slimībām slimojošo reǵistrs (PREDA). 1991. https://www.spkc.gov.lv/lv/.

108. Superstein, R., Archer, S. M., Del Monte, M. A. (2002). Minimal Myopic Shift in Pseudophakic Versus Aphakic Pediatric Cataract Patients. J AAPOS. 6, 271-276.

109. Taylor, D. The History of the Management of Congenital Cataract. In: Lloyd, I. C., Lambert, S. C., editors. (2017). Congenital Cataract: A Concise Guide to Diagnosis and Management. Switzerland: Springer International Publishing. 3-14.

110. Taylor, D., Wright, K. W., Amaya, I., Cassidy, L., Nischal, K. K., Russell-Eggitt, I. (2001). Should we aggresively treat unilateral congenital cataracts? Br J Ophthalmol. 85.

111. Traboulsi, E. I., Utz, V. M., editors. (2016). Practical Management of Pediatric Ocular Disorders and Strabismus.

112. Trivedi, R. H., Wilson, M. E., editors. (2002). Axial length and keratometry in eyes with pediatric cataract. 
113. Trivedi, R. H., Wilson, M. E. Epidemiology of Pediatric Cataracts and Associated Blindness. In: Wilson, M. E., Trivedi, R. H., Pandey, S. K., editors. (2005). Pediatric Cataract Surgery: Lippincot Williams\&Wilkins. 18-21.

114. Trivedi, R. H., Wilson, M. E. (2016). Myopic Shift in Pseudophakic and Aphakic Eyes of Children. Ento Key.

115. Trivedi, R. H., Wilson, M. E., Facciani, J., editors. (2004). Interocular axial length difference.

116. Troilo, D., Wallman, J. (1991). The regulation of eye growth and refractive state: an experimental study of emmetropization. Vision Research. 31, 1237-1250.

117. Tromans, C., Haigh., P., M., Biswas, S., Lloyd, I. C. (2001). Accuracy of intraocular lens power calculation in paediatric cataract surgery. Br J Ophthalmol. 85, 939-941.

118. Tromans, C., Wilson, H. The Refractive Management of Infantile Aphakia and Pseudophakia. In: Lloyd, I. C., Lambert, S. C., editors. (2017). Congenital Cataract: A Concise Guide to Diagnosis and Management. Switzerland: Springer International Publishing. 165-172.

119. Valeiņa, S., Pastare, M., Klindzane, M., editors. (2013). Pētījums par iedzimtu kataraktu skrīninga metodi un iespējām.

120. Valera Cornejo, D. A., Flores, Boza, A. (2018). Relationship between preoperative axial lengh and myopic shift over 3 years after congenital cataract surgery with primary intraocular lens implantation at the National Institute of Ophthalmology of Peru, 2007-2011. Clin Ophthalmol. 12, 395-399. doi:10.2147/OPTH.S152560.

121. VanderVeen, D. K. Selecting an Intraocular Lens Power. In: Lloyd, I. C., Lambert S. C., editors. (2017). Congenital Cataract:: A Concise Guide to Diagnosis and Management. Switzerland: Springer International Publishing. 91-99.

122. VanderVeen, D. K., Nizam, A., Lynn, M. J., Bothun, E. D., McClatchey, S. K., Weakley, D. R., et al. (2012). Predictability of intraocular lens calculation and early refractive status: the infant aphakia treatment study. Arch Ophthalmol.130, 293-299.

123. Weakley, D. R., Lynn, M. J., DuBois, L. G., Cotsonis, G. A., Wilson, M. E., Buckley, E. G., et al. (2017). Myopic Shift 5 years after intraocular lens implantation in the Infant Aphakia Treatment study. Ophthalmology. 124, 822-827. doi:10.1016/j.optha.2016.12.040.

124. Wiesel, T. N., Raviola, E. (1977). Myopia and eye anlargement after neonatal lid fusion in monkeys. Nature. 266.

125. Wigle, J. T., Chowdhury, K., Gruss, P., Oliver. G. (1999). Prox 1 function is crucial for mouse lensfibre elongation. Nat Genet. 318-322.

126. Wilson, M., Trivedi, R. H., Pandey, S. K., editors. (2005). Pediatric Cataract Surgery: Techniques, complications, and Management. Etiology and Morphology of Pediatric Cataracts. 6-11.

127. Wilson, M. E. (2015). Pediatric Cataracts: Overview. https://www.aao.org/pediatric-center-detail/ pediatric-cataracts-overview. Accessed 11 Nov 2015.

128. Wilson, M. E., Trivedi, R. H. My Preferred Approach. In: Wilson, M., Trivedi, R. H., Pandey, S. K., editors. (2005). Pediatric Cataract Surgery: Techniques, complications, and Management. Etiology and Morphology of Pediatric Cataracts. 6-11; 321-331.

129. Wilson, M. E., Trivedi, R. H. Strabismus in Pediatric Aphakia and Pseudophakia. In: Wilson, M. E., Trivedi, R. H., Pandey, S. K., editors. (2005). Pediatric Cataract Surgery: Lippincot Williams\& Wilkins. 254-256.

130. Wilson, M. E., Trivedi, R. H., Morrison, D. G., Lambert, S. R., et al. (2011). Infant aphakia traetment study: Evaluation of cataract morphology in eyes with monocular cataracts. J AAPOS. 15, 421-426. doi:10.1016/jaapos2011.05.016. 
131. Wilson, M. E., Trivedi, R. H., Pandey, S. K., editors. (2005). Pediatric Cataract Surgery: Lippincot Williams\&Wilkins.

132. Wilson, M. E., Wood, K. S., Trivedi, R. H. Lensectomy and Anterior Vitrectomy. In: Lloyd, I.C., Lambert, S. C., editors. (2017). Congenital Cataract: A Concise Guide to Diagnosis and Management. Switzerland: Springer International Publishing. 83-89.

133. Wirtht, M. G., Russell-Eggitt, I., Craig, J. E., et al. (2002). Aetiology of congenital and pediatric cataract in Australian population. Br J Ophthalmol. 86, 782-786.

134. World Health Organization 2007. World Health Organization 2007, Global initiative for the elimination of avoidable blindness: action plan 2006-2011. Accessed Aug 2011. URL: http:// www.who.int/blindness/Vision2020_report.pdf.

135. Wright, K. W., Kolin, T., Matsumoto, E., editors. (1995). Lens abnormalities. Pediatric Ophthalmology and Strabismus: Mosby.

136. Yackle, K. F. D. (1999). Emmetropization. An Overview. Journal of Behavioral Optometry. 10, $38-43$.

137. Zuber, M. E., Gestri, G., Viczian, A. S. (2003). Specxification of the vertebrate eye by a network of eye field transcription factors. Development. 5155-5167. 
PIELIKUMI 


\title{
1. pielikums
}

\section{Ėtikas komitejas aţ̦auja}

\author{
Veselības ministrija \\ Valsts sabiedrība ar ierobežotu atbildību \\ „Bērnu klīniskā universitātes slimnīca”
}

Reg. Nr. 40003457128

Ẽtikas komitejas

atzinums.

Bērnu klīniskās universitātes slimnīcas Ētikas komiteja 09.12.2010. sēdē izvērtēja
RSU doktorantes Sandras Valeiņas iesniegtos dokumentus, saistībā ar plānoto
pētījumu „Redzes funkciju salīdzinošs izvērtējums iedzimtu kataraktu pacientiem
atkarībā no intraokulārās lēcas mērḳa stipruma, veida un implantācijas laika” Bērnu
klīniskajā universitātes slimnīcā.
Êtikas komiteja uzskata, ka pētījums atbilst medicīnas ētikas prasībām, un iesaka
ațaut to īstenot Bērnu slimnīcas apstākḷos.
09.12.2010. 


\title{
Pacientu informētās piekrišanas forma
}

\author{
Pētījuma „Redzes funkciju salīdzinošs izvērtējums iedzimtu \\ kataraktu pacientiem atkarībā no intraokulārās lēcas mērķa stipruma, \\ veida un implantācijas laika". Skaidrojums slimniekam, slimnieka \\ vecākiem (aizbildnim) aţ̦aujas saṇemšanai bērna izmeklējumu un \\ ārstēšanas datu izmantošanai pētījumā.
}

Iedzimtas kataraktas ir viens no bērnu redzes invaliditātes nopietnākajiem un biežākajiem cēloṇiem. Iedzimtu kataraktu biežums no dažādiem literatūras avotiem ir 2.2 līdz 3.46 uz 10000 jaundzimušo. Latvijā katru gadu tiek veiktas no 16-22 iedzimtu kataraktu ekstrakciju operācijas. Pēc apdulķoto lēcu masu ekstrakcijas, lai atjaunotu emetropu acs refrakciju un varētu attīstīties bērna redze, zīdaiņa acī iztrūkstošās dioptrijas jāaizvieto ar brillēm, kontaktlēcām vai intraokulārajām lēcām. Aprēķinot IOL mērķa stiprumu var izvēlēties acs emetropu vai hipermetropu sākuma refrakciju. Atkarībā no sākuma refrakcijas acs augot miopizēsies, kas savukārt var ietekmēt redzes attīstỉbu un ambliopijas iespējamo rašanos.

Lai izanalizētu iedzimtu kataraktu ārstēšanas iespējas un rezultātus BKUS un Latvijā, Jūsu bērna izmeklēšanas un ārstēšanas dati, kas atspoguḷojas pacienta stacionāra un ambulatorajās slimības vēsturēs, tiks ieklauti pētījumā „Redzes funkciju salīdzinošs izvērtējums iedzimtu kataraktu pacientiem atkarībā no intraokulārās lēcas mērka stipruma, veida un implantācijas laika”.

Konfidencialitāte. Visi personas dati tiks savākti atbilstoši juridiskajiem standartiem. Dati par pētījuma ieklautajām personām tiks glabāti konfidenciāli un nebūs publiski pieejami. Ja pētījuma rezultāti tiks publicēti, personu identitāte paliks konfidenciāla. pētījumā.

Apliecinu, ka piekrītu mana bērna izmeklēšanas un ārstēšanas datu izmantošanai

Slimnieks: .(Vārds, Uzvārds)

Slimnieka vecāki (aizbildnis): .(Vārds, Uzvārds)

Slimnieka vecāku paraksts: 


\section{PATEICĪBAS}

Izsaku dziļu pateicību:

- Inese Valeiņa un Vladislavs Valeiņa

- Guntis Ošmucnieks un Daina Ošmucniece

- Mārtinsš Ošmucnieks

- Anna Bogustova un Paulis Ošmucnieks

- Ģirts Valeiņa un Indra Valeiņa

- Guna Laganovska

- Aija Žileviča

- Iveta Strupka

- Renārs Erts

- David Taylor

- Juris Rubenis

- Jānis Dzenis

- Santa Heede

- Zita Krūmiña

- Elīza Anna Stūre

- Sandra Kudina

- Ieva Mik̦elsone

- Ināra Ābelīte

- Egīls Pārups

- Aija Lapsa

- Indra Galina

- Antra Treija un Gints Treijs

- Artur Klett

- Kuldar Kaljurand

- Arnis Enǵelis

- Dominique Bremond- Gignac

- Kolēǵiem no BKUS Acu slimību klīnikas un citām klīnikām

- Pacientiem un viņu vecākiem 